\title{
A revision of Annularia and Asterophyllites species from the lower Westphalian (Middle Pennsylvanian) of the Maritime Provinces of Canada
}

\author{
Carmen Álvarez-VÁzquez ${ }^{*}$ ANd Robert H. Wagner \\ Centro Paleobotánico, Real Jardín Botánico de Córdoba, Avenida de Linneo, s/n, 14004 Córdoba, Spain. \\ *Corresponding author <paleo.calvarez@jardinbotanicodecordoba.com>
}

Received 15 January 2016 accepted 28 November 2016

\begin{abstract}
As part of a larger project to revise the systematics of lower Westphalian floras of Nova Scotia and New Brunswick, the sphenopsid taxa are presently reviewed. We recognize 15 species, of which one, Annularia stopesiae, is new. Detailed synonymy lists allow a refinement of the stratigraphic and geographic ranges of these species. Scant attention has been paid previously to Canadian species in the European literature. For example, Annularia latifolia was described later from Europe as Annularia jongmansii. The identical composition of Westphalian floras from Canada and western Europe is striking.
\end{abstract}

\section{RÉSUMÉ}

La révision de la flore du Westphalien inférieur de Nouvelle Écosse et Nouveau Brunswick a été continué à présent avec les sphénopsides. Nous avons reconnu quinze espèces, y compris une nouvelle, Annularia stopesiae. L'analyse des synonymies a permis établir l'extension stratigraphique ainsi que la répartition géographique de cettes espèces. On constate que les auteurs européens ignoraient souvent les espèces décrites au Canada. Un example à citer est Annularia latifolia qui est la même espèce qu'Annularia jongmansii décrite en Europe. On constate ausssi, une fois de plus, que la flore westphalienne est identique pour l'Europe occidentale et Canada.

[Traduit par la redaction] 


\section{INTRODUCTION}

While engaged in the taxonomic revision of upper Namurian to middle Westphalian floras of the Maritime Provinces of Canada, it became apparent that certain forms of the sphenopsid fossil-genera Annularia and Asterophyllites needed special attention in a broader context. Some of the species of these genera were first described from Canada, but have been referred to only rarely or not at all in the western European literature, despite the palaeogeographic proximity between the Maritime Provinces and Europe, the British Isles in particular. Conversely, some species described from Europe were used only sparingly in Canada and the United States. A more thorough comparison was clearly required. This has led to the recognition of several synonyms, thus leaving a smaller number of accepted species. The oft-quoted resemblance of the Westphalian floras of Canada with those of western Europe is reinforced by a thorough taxonomic revision. Several of Bell's (1944) and Matthew's (1906a, b) specimens are refigured from museum collections. Additional material from New Brunswick and Nova Scotia is also documented.

\section{TAXONOMIC HISTORY}

From the classic Fern Ledges locality at Saint John, New Brunswick, Dawson (1861) described as new Asterophyllites parvulus (corrected spelling by Jongmans 1914b; originally Asterophyllites parvula), which Stopes (1914) compared with Asterophyllites grandis and Bell (1944) synonymized with Asterophyllites charaeformis. Dawson (1862) introduced Annularia acicularis and Annularia latifolia (both initially attributed to Asterophyllites). Stopes (1914) compared Annularia acicularis with Annularia radiata and Asterophyllites equisetiformis, and Annularia latifolia with Annularia stellata. Another species introduced by Dawson in 1862 was Asterophyllites? scutigerus (corrected spelling) for what appear to be stems of Calamites (Dawson's pl. XIII, figs. 18, 20). He also recorded a strobilus (his pl. XIII, fig. 19) and Annularia acuminata, a species that Dawson refigured in 1871 as Sporangites acuminata and comprises sporangial clusters. Dawson (1871) additionally described Asterophyllites lentus (corrected spelling by Matthew 1906a). One of Dawson's specimens of Asterophyllites lentus was refigured by Stopes (1914) as Asterophyllites sp. and compared with Annularia radiata. Bell (1944) synonymized Asterophyllites lentus with Annularia acicularis.

Also from Fern Ledges, Matthew (1906a) described Asterophyllites fasciculatus. As Stopes (1914) pointed out, this name was preoccupied, having been used previously by Lesquereux (1879-1880) for a different species from Clinton, Missouri. Although fragmentary and poorly preserved, Matthew's material might be attributable to
Asterophyllites longifolius. Matthew (1906a) described two additional specimens as Asterophyllites? fissus and Annularia longifolia mutation leavittii. The former is here referred to Asterophyllites longifolius. Stopes (1914) assigned Annularia longifolia mutation leavittii (figured photographically in Matthew 1906b, pl. IX) to Annularia stellata, but we regard it as belonging to Annularia inflata Lesquereux. Two specimens recorded as Annularia recurva by Matthew (1906a) were referred to Annularia acicularis by Bell (1944), albeit with doubt. Stopes (1914) regarded these two specimens and a more fragmentary one, described by Matthew (1906a) as Annularia? ligata, as indeterminable; we concur. Annularia latifolia var. minor, as described by Matthew (1906a), was compared by Stopes (1914) to Annularia stellata, but retained in Annularia latifolia because of a (slightly) greater width of leaves in the Canadian material. We regard Annularia latifolia var. minor as a synonym of Annularia galioides. We also assign to Annularia galioides a specimen from Fern Ledges figured by Bell (1966, pl. VII, fig. 3) as Annularia latifolia.

Among the sphenopsids from Fern Ledges, Stopes (1914, pl. V, fig. 7) figured a specimen as Annularia sphenophylloides. We agree with Bell (1944), that this specimen was misidentified and should be referred to Annularia latifolia.

Bell (1944) incorporated material from New Brunswick with his description of fossil plants from the Cumberland Basin in northern Nova Scotia. He discussed Annularia latifolia extensively, and regarded Annularia latifolia var. minor of Matthew (1906a) as falling within the range of variation of Annularia latifolia without necessitating a separate variety. As mentioned above, we regard Annularia latifolia var. minor as belonging to Annularia galioides. Bell (1944) introduced two new species, Annularia aculeata and Annularia asteris. The former was typified by material from Inverness County, Cape Breton Island, Nova Scotia, whereas the latter came from Tynemouth Creek, near Saint John, New Brunswick, from a level equivalent to that at Fern Ledges. Annulariaaculeata is here regarded as founded on a mixture of Annularia ramosa, Asterophyllites grandis and Asterophyllites charaeformis (see below). Bell $(1944,1966)$ also figured two specimens from Springhill, Nova Scotia, as Annularia stellata forma longifolia. These specimens are refigured here and described as a new species, Annularia stopesiae.

The Canadian record contains fewer species than the publications suggest. Our critical revision emphasizes its similarity with the western European record.

\section{REPOSITORY OF SPECIMENS, LOCALITY AND CATALOGUE NUMBERS}

The specimens used for the current revision are in the collections of the Geological Survey of Canada, Ottawa (catalogue numbers preceded by GSC) and the New Brunswick Museum (NBMG). More complete information 
about GSC localities can be found in the memoirs published by Bell (1938, pp. 108-115; 1940, pp. 133-139; 1944, pp. 111-118; 1962, pp. 63-64).

\section{SYSTEMATIC PALAEOBOTANY}

As in our previous revision of the Lycopsida (ÁlvarezVázquez and Wagner 2014), partial lists of synonymy are provided with special emphasis on types and listing all the illustrated records from Canada and the United States for the Middle Pennsylvanian time interval. European records are selective. However, all synonyms as accepted by the present authors are included. Descriptions, comparisons and remarks are included as well as stratigraphic and geographic distributions, and occurrence in Canada and the United States. Stratigraphic occurrences are given in accordance with the western European regional chronostratigraphic subdivisions of the Pennsylvanian Subsystem.

Annotations in the synonymy lists follow those of Cleal et al. $\left(1996\right.$ - shortened/simplified): ${ }^{\star}=$ protologue; $\S=$ first publication of currently accepted combination; $\mathrm{T}=$ others' photographic illustrations of the type material; ? = references todoubtful specimens due to poor illustration or preservation; $\mathrm{p}$ (pars) $=$ only part of the specimens published belong to the species; $\mathrm{v}$ (vide) $=$ the authors have seen the specimen $(\mathrm{s})$; $\mathrm{cf}$. = comparable; $\mathrm{k}=$ reference includes cuticular evidence; acc. to $=$ according to.

The various species recognized in the Maritime Provinces will be dealt with in alphabetical order within the adpression genera Annularia and Asterophyllites, which are based on leaves.

Class Equisetopsida Takhtajan ex Nĕmejc 1963 Family Calamitaceae Unger 1840

\section{Genus Annularia Sternberg 1821}

1820 Casuarinites Schlotheim, p. 397 (illegitimate name).

1821 Annularia Sternberg, pp. 28, 32.

p 1825 Bornia Sternberg, p. 324.

1860 Trochophyllum Wood, p. 438 (see Abbott 1958).

TYPE: Annularia spinulosa Sternberg 1821

REMARKS: Annularia and Asterophyllites incorporate small Calamites-type articulate axes bearing leaf verticils at each articulation (node). Both genera have singleveined leaves which are more or less united at the base in each verticil. However, the leaves of Annularia are linearlanceolate, lanceolate or spatulate, with the broadest part in the middle of the leaf or near the apex; Asterophyllites has narrower, almost parallel-sided leaves, with the broadest part in the lower third, and a pointed apex. Verticils of Annularia are usually found as dorsi-ventral adpressions spread out on the bedding plane; leaf whorls in Annularia are either isophyllous or markedly anisophyllous. In contrast, the leaves of Asterophyllites are usually preserved flattened sideways, parallel to the axis. However, in practice, it is not always possible to separate Annularia from Asterophyllites in view of the important role played by preservational characters.

Tables 1 and 2 summarize the morphological characters and numerical values of measurements for the different species of Annularia and Asterophyllites.

\section{Annularia asteris Bell 1944}

(Figs. 1a-e)

1869 Annularia minuta, Wood, pp. 347-348, pl. VIII, fig. 2 (acc. to Abbott 1958).

1884a Annularia minuta?, Lesquereux, pp. 725-726, pl. XCII, figs. 8-8a.

1917 Annularia spicata, Kidston et al., pp. 1039-1041, pl. II, figs. 6-7a.

1934 Annularia sp., Arnold, p. 187, pl. I, figs. 2, 4 (acc. to Arnold 1949, p. 183).

*v 1944 Annularia asteris Bell, pp. 102-103, pl. LXVII, fig. 3 (holotype - partially refigured here as Figs. la-c); pl. LXVIII, fig. 5 (enlargement of holotype).

1949 Annularia asteris, Arnold, p. 183, pl. XVI, fig. 5 (same as Arnold 1934, pl. I, fig. 2).

* 1952-53 Annularia subradiata Stockmans and Willière, pp. 176-177, pl. XXVI, figs. 9-9a (only a brief diagnosis was provided by Stockmans and Willière, who compared with Annularia radiata).

p 1958 Annularia asteris, Abbott, pp. 310-311, pl. 49, figs. 88, 89 (same specimen as Wood 1869, pl. VIII, fig. 2); non pl. 35, fig. 7 (= Annularia galioides); non pl. 39, fig. 48 (= Annularia galioides); non pl. 40, fig. 54 (= Annularia galioides); non chart 2.

1969 Annularia spicata, Crookall, pp. 744-745, pl. CXXIV, fig. 3.

1988 Annularia subradiata, Tidwell et al., p. 24, figs. 31-32.

p 1991 Annularia ramosa, Josten, Taf. 20, fig. 1; non pp. 75-77, Taf. 20, figs. 2-2a (= Annularia ramosa); Abb. 33 (= Annularia ramosa - drawing).

? 2000 Annularia subradiata, Purkyňová, p. 2, textfig. 1 (drawing).

? 2000 Annularia asteris, Purkyňová, pp. 2-3, textfig. 2 (drawing).

Excludenda:

1961 Annularia asteris, Leggewie and Schonefeld, pp. 29-30, Taf. 24, figs. 3-4 (= Annularia galioides); Taf. 26, figs. 7-8 (= Annularia galioides).

1963 Annularia cf. asteris, Cridland et al., p. 70, pl. 18, fig. 22 (maybe Annularia spicata).

1977 Annularia cf. asteris, Leary and Pfefferkorn, p. 7, pl. 1, fig. 6 (= Annularia sp. - leaves with a 
Table 1. Parameters used for the discrimination of the different species of Annularia in the Maritime Provinces.

\begin{tabular}{|c|c|c|c|c|c|c|}
\hline & $\begin{array}{l}\text { internode } \\
\text { length }\end{array}$ & $\begin{array}{c}\text { leaves per } \\
\text { verticil }\end{array}$ & leaf form & apex & length & $\begin{array}{c}\text { length/breadth } \\
\text { ratio }\end{array}$ \\
\hline A. asteris & $2.25-3 \mathrm{~mm}$ & $8-10$ & parallel-sided & acuminate & $2-4.5 \mathrm{~mm}$ & $10-18$ \\
\hline A. fertilis & $25 \mathrm{~mm}$ & $14-16$ & oblong & $\begin{array}{c}\text { acute, } \\
\text { mucronate }\end{array}$ & $9-17 \mathrm{~mm}$ & $4.5-8.5$ \\
\hline A. galioides & $10-15 \mathrm{~mm}$ & $10-12$ & oblanceolate & obtuse & $4-6 \mathrm{~mm}$ & $4-5$ \\
\hline A. inflata & $20-25 \mathrm{~mm}$ & $22-24$ & oblanceolate & $\begin{array}{c}\text { obtuse, } \\
\text { mucronate }\end{array}$ & $\begin{array}{c}20-25 / 30-45 \\
\mathrm{~mm}\end{array}$ & $8-10$ \\
\hline A. latifolia & $10-12 \mathrm{~mm}$ & $12-16$ & oblanceolate & $\begin{array}{c}\text { obtuse, } \\
\text { mucronate }\end{array}$ & $8-12 \mathrm{~mm}$ & $\sim 6$ \\
\hline A. microphylla & $4.5-5 \mathrm{~mm}$ & 12 & sickle-shaped & acute & $5-6 \mathrm{~mm}$ & 10 \\
\hline A. pseudostellata & $9-14 \mathrm{~mm}$ & $10-14$ & linear & - & $\begin{array}{c}20-25 \mathrm{~mm} \\
\text { (incomplete) }\end{array}$ & $\sim 50$ \\
\hline A. radiata & $10-25 \mathrm{~mm}$ & $12-16$ & $\begin{array}{l}\text { linear- } \\
\text { lanceolate }\end{array}$ & acute & $11-24 \mathrm{~mm}$ & $11-16$ \\
\hline A. ramosa & $20 \mathrm{~mm}$ & $8-12$ & $\begin{array}{c}\text { linear- } \\
\text { lanceolate }\end{array}$ & acute & $3.5-8 \mathrm{~mm}$ & $23-26$ \\
\hline A. stopesiae & $16-45 \mathrm{~mm}$ & $20-24$ & $\begin{array}{c}\text { linear- } \\
\text { lanceolate }\end{array}$ & acute & up to $85 \mathrm{~mm}$ & $50-56$ \\
\hline
\end{tabular}

Table 2. Parameters used for the discrimination of the different species of Asterophyllites in the Maritime Provinces.

$\begin{array}{ccccc}\text { internode } & \begin{array}{c}\text { leaves per } \\ \text { length }\end{array} & \text { verticil }\end{array}$ leaf form apex length $\begin{gathered}\text { length/breadth } \\ \text { ratio }\end{gathered}$
$\begin{array}{lllll}\text { A. charaeformis } & 2-3 \mathrm{~mm} & \text { up to } 10 \quad \text { reflexed } & \text { acute } & 2-3 \mathrm{~mm}\end{array}$
$\begin{array}{lllll}\text { A. grandis } \quad 2.5-4 \mathrm{~mm} \quad \text { - } & \text { curved } \quad \text { acute } \quad 4-6 \mathrm{~mm}\end{array}$

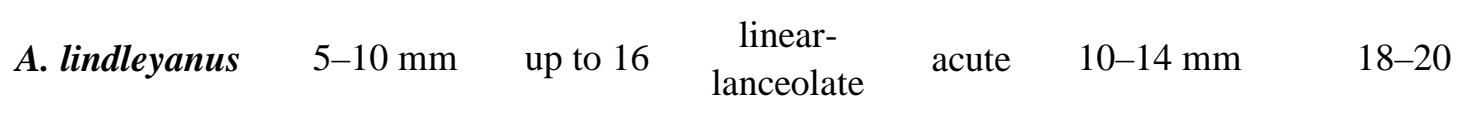

$\begin{array}{lllll}\text { A. longifolius } \quad 8-14 \mathrm{~mm} & \text { up to } 20 \quad \text { filiform } \quad \text { acute } \quad 25-40 \mathrm{~mm} \quad 25-40\end{array}$ 

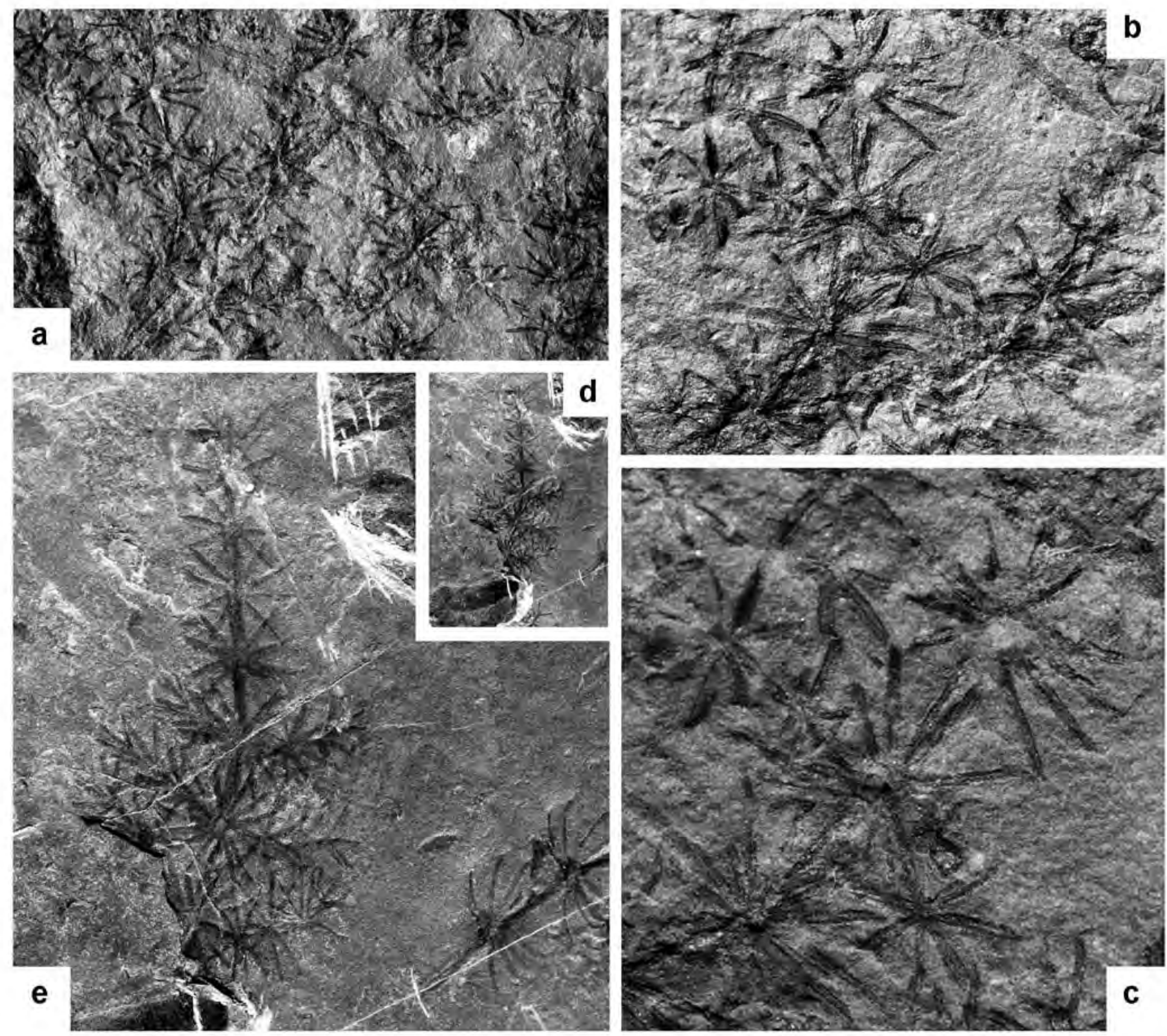

Figure 1. (a) Annularia asteris (x 3). GSC 9805. Detail of part of the holotype. Previously figured by Bell (1944, pl. LXVII, fig. 3; pl. LXVIII, fig. 5). Origin: east shore of Tynemouth Creek, Saint John, New Brunswick (locality 642). Repository: Geological Survey of Canada, Ottawa. (b) Annularia asteris. Enlargement (x 6) of specimen in Fig. 1a. (c) Annularia asteris. Another enlargement (x 9) of part of the same specimen. (d) Annularia asteris (x 1). NMBG 3436. Penultimate branch bearing verticils with the characteristic stiff, narrow, small leaves. Specimen on the same slab as that figured by Matthew (1906a, pl. VI, fig. 3) as Asterophyllites parvulus, here included in Asterophyllites charaeformis (see Fig. 13). Origin: Bed 2, Fern Ledges, Saint John, Lancaster, New Brunswick. Repository: New Brunswick Museum, Saint John. (e) Annularia asteris. Enlargement (x 3) of specimen in Fig. 1d.

more fleshy lamina than that of Annularia asteris, and of a size that is too small for Annularia galioides) (specimen mentioned previously by Leary 1976, p.

1978 Annularia asteris, Gillespie et al., pp. 71, 74, 79, pl. 26, fig. 5 (= Annularia galioides).
1983 Annularia asteris, Winston, pp. 7, 8, 13, pl. II, fig. 4 (= Annularia spicata).

1985 Annularia asteris, Gillespie and Rheams, pp. 194, 196, pl. I, fig. 2 (= Annularia ramosa).

1985 Annularia asteris, Gillespie and Crawford, pp. 252, 255, pl. III, fig. 2 (= Annularia ramosa). 
1987 Annularia asteris, Tenchov, p. 38, pl. XII, figs. 1-3 (more fleshy leaves; Asterophyllites sp. indet.?).

1991 Annularia asteris, Josten, pp. 86-87, Taf. 23, figs. 7-8a (fragmentary and poorly preserved lanceolate leaves resembling Annularia galioides); Abb. 41 (drawing).

1992 Annularia cf. asteris, Mamay and Mapes, Fig. 2.E (= Annularia spicata acc. to DiMichele et al. 2013, p. 290).

1996 Annularia asteris, Cross et al., pp. 406, 442, fig. 23-12.2 (= Annularia cf. galioides).

DESCRIPTION: Ultimate axes $0.2-0.3 \mathrm{~mm}$ wide, inserted suboppositely at a wide angle $\left(80-90^{\circ}\right)$. Internodes $2.25-3$ $\mathrm{mm}$ apart, bearing closely spaced verticils that overlap slightly in spread-out preservation. Verticils with 8 to 10 leaves of equal length and united at the base so as to form an annulus; they are stiff, narrow, with nearly parallel sides, though sometimes slightly wider across the middle; apex acuminate. Dimensions: $2-4.5 \mathrm{~mm}$ long at $0.20-0.25$ $\mathrm{mm}$ width; length/breadth ratio $=10-18$. Vein not visible.

REMARKS: Although widely reported, particularly in the United States, Annularia asteris has been generally misidentified. Bell (1944, pl. LXVII, fig. 3; pl. LXVIII, fig. 5) figured only one specimen (the holotype) from Tynemouth Creek, New Brunswick. Although well preserved, additional material is required to show the full range of morphological variation.

In addition to Bell's holotype, we figure as Annularia asteris a specimen from Fern Ledges at Saint John, New Brunswick, which is preserved on the same bedding plane as the type of Asterophyllites parvulus (= Asterophyllites charaeformis) (Matthew 1906a, pl. VI, fig. 3). At first, we considered that both specimens might belong to a single species (as Matthew may have thought). However, Asterophyllites charaeformis has small, reflexed, thread-like leaves that are preserved parallel to the axis, whereas Annularia asteris displays (equally small) leaves that are most commonly preserved in spread-out (dorsiventral) position (see Figs. 1a-c; parts of the holotype).

Annularia asteris was recorded from West Virginia as Annularia minuta by Wood (1869) and Lesquereux (1884a). However, this name had been used already by Brongniart $(1828 \mathrm{a}$, pp. 155, 175) as a nomen nudum referring to specimens from the Stephanian of Terrasson, Aquitaine, southwestern France. Brongniart's specimens were illustrated by Zeiller (1892, pl. XI, figs. 2, 3), who referred them to Annularia spicata, a late Stephanian species. We concur.

COMPARISONS: Bell (1944) compared Annularia asteris with Annularia galioides and its synonym Annularia cuspidata. The narrow, almost thread-like leaves of Annularia asteris are quite different to the more fleshy ones of Annularia galioides. Also, the leaves of the latter species are oblanceolate and possess a smaller length/ breadth ratio. Annularia minima is another similar smallleaved species. However, its leaves are not as thread-like as those of Annularia asteris. Leggewie and Schonefeld (1961) observed that the leaves of Annularia minima are widest around the middle. Annularia ramosa possesses larger, linear-lanceolate leaves that have a length/breadth ratio between 23 and 26, and a more fleshy appearance.

STRATIGRAPHIC AND GEOGRAPHIC DISTRIBUTION: Annularia asteris has been rarely recorded. In Europe, the type material of the synonymous Annulariasubradiata isfrom upper Namurian (Yeadonian) strata of the Assise d'Andenne, Belgium. The specimen (assigned to Annularia ramosa) by Josten (1991) came from the Langsettian of the Ruhr District, western Germany. Kidston et al. (1917) recorded this species (misidentified as Annularia spicata) from the lower Bolsovian of the Forest of Wyre in England. Crookall's (1969) specimen came from the Bolsovian of South Staffordshire, alsoinEngland.The material of Purkyňová (2000) originated from Kinderscoutian to Langsettian strata of the Upper Silesian Coal Basin, in the Moravian part of the Czech Republic.

OCCURRENCE IN THE MARITIME PROVINCES: Cumberland Basin (Nova Scotia): Bell (1944): locality 1087 (one piece without catalogue number); locality 1088 (GSC 10094 - together with Asterophyllites charaeformis + GSC 10099 + GSC 10100 - cf.; poorly preserved + GSC 10102 - cf.; together with Calamites sp. + GSC 10103 - cf. + GSC 10104 - cf. + GSC 10105 - cf.; together with Calamites sp. + GSC 10109). Tynemouth Creek (New Brunswick): Bell (1944): locality 642 (GSC 9805 - holotype; here Figs. 1a-c; together with Laveineopteris polymorpha on the same specimen). Fern Ledges (New BRUNSWICK): New Brunswick Museum collection: NBMG 3435 + NBMG 3436 (see Figs. 1d-e; together with Asterophyllites charaeformis and Alethopteris sp. indet.).

OCCURRENCE IN THE UNITED STATES: MiCHIGAN: Arnold (1934, 1949). UTAH: Tidwell et al. (1988). West Virginia: Wood (1869); Lesquereux (1884a); Abbott (1958).

\section{Annularia fertilis Sternberg 1825}

(Figs. 2a-e)

* 1825 Annularia fertilis Sternberg, p. 43, Taf. LI, fig. 2.

p 1862 Asterophyllites latifolia Dawson, pl. XIII, fig. 17c; non p. 311, pl. XIII, figs. 17a-b (= Annularia latifolia).

p 1868 Asterophyllites latifolia Dawson, Fig. 187D (same as Dawson 1862, pl. XIII, fig. 17c); non p. 538, Fig. 187A (Annularia latifolia - same as Dawson 1862, pl. XIII, figs. 17a-b); non Fig. 187B (?).

p 1886-88 Annularia radiata, Zeiller, pl. LXI, figs. 2, 2A; 

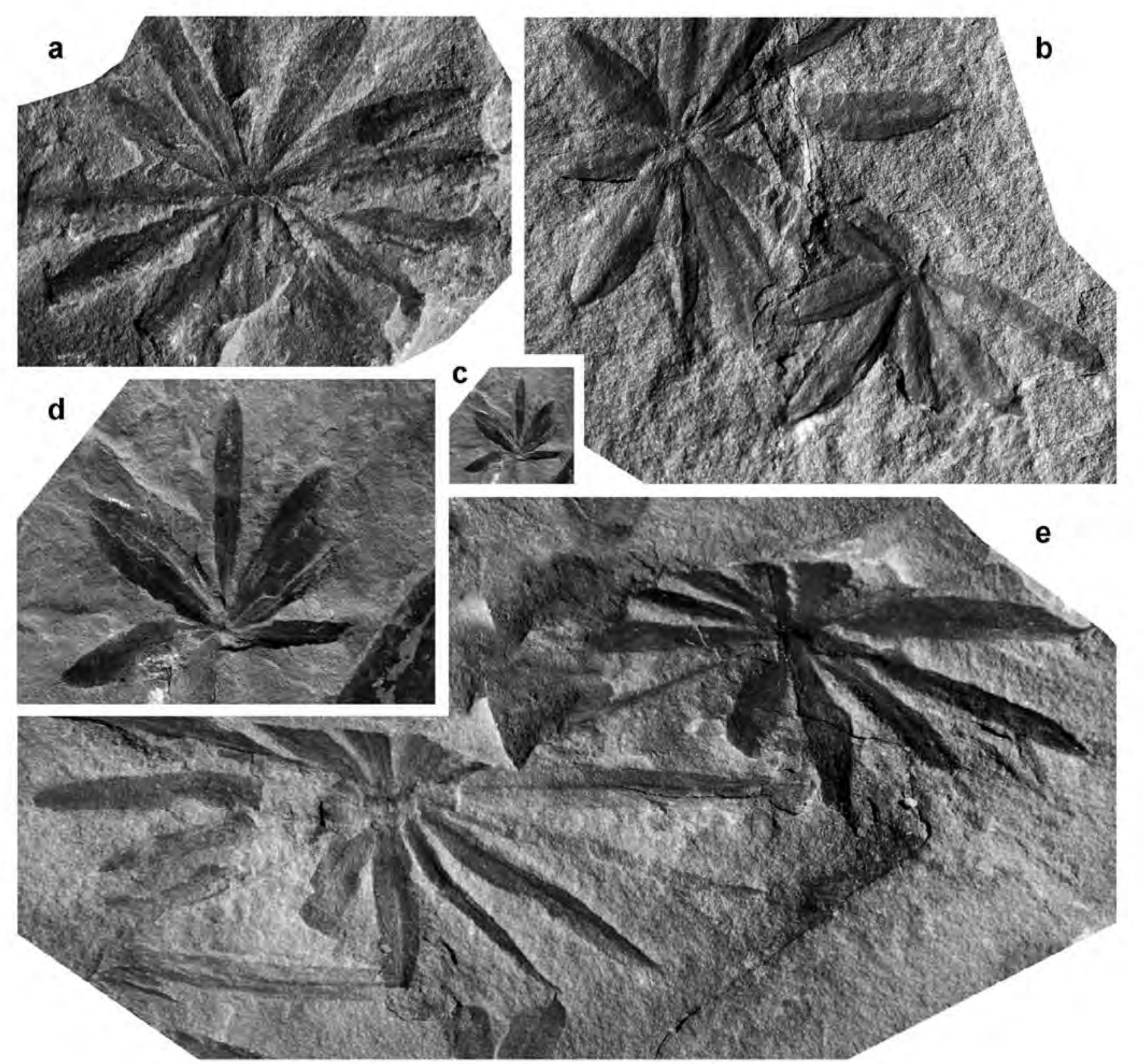

Figure 2. (a) Annularia fertilis (x 3). Verticil showing leaves with a strongly marked vein. Origin: east of Tynemouth Creek and east of anticline, Saint John, New Brunswick (locality $2577=1594)$. (b) Annularia fertilis (x 3). Specimen showing fleshy leaves (no locality stated; no locality number). (c) Annularia fertilis (x 1). Incomplete leaf verticil. Origin: same as for Fig. 2a (locality 1594). (d) Annularia fertilis. Enlargement (x 3) of specimen in Fig. 2c. (e) Annularia fertilis (x 3 ). Verticils slightly deformed tectonically. Origin: same as for Fig. 2a (locality 2577). Repository of all specimens: Geological Survey of Canada, Ottawa.

non pp. 394-398, pl. LIX, fig. 8 (= Annularia radiata and Calamostachys); non pl. LXI, figs. 1, 1A (= Annularia radiata).

p 1906a Annularia latifolia, Matthew, pp. 125-126, pl. VII, fig. 2; non pl. VII, fig. 3 (= Annularia galioides). p 1914 Annularia latifolia [= A. stellata?], Stopes, pl. VI, fig. 11; non pp. 23-24, pl. VI, fig. 10 (= Annularia latifolia - photograph of Dawson 1871, 
pl. V, fig. 51); non pl. VI, fig. 12 (= Annularia latifolia); non pl. VII,fig. 13 (= Annularia latifolia).

1949 Annularia radiata, Arnold, pp. 183-184, pl.XVII, fig. 3.

1959 Annularia jongmansii, Gothan et al., pp. 44-45, Taf. 12, figs. 2-4.

p 1961 Annularia fertilis, Leggewie and Schonefeld, pp. 25-26, Taf. 15, figs. 5-6; Taf. 16, figs. 1-4; non Taf. 16, figs. 5-6 (diaphragm of Calamites).

1962 Annularia radiata var. karvinensis, Purkyňová, p. 45, Tab. X, fig. 3.

cf.1963 Annularia radiata, Wood, pp. 40-41, pl. 3, fig. 8 (leaf shape and size are similar to those of Annulariafertilis, but Wood's specimen possesses more leaves per verticil).

cf.1963 Annularia stellata, Wood, pp. 41-43, pl. 4, fig. 1 (more leaves per verticil).

p 1980 Annularia radiata, Zodrow and McCandlish, pl. 91, fig. 1; non pl. 91, fig. 2 (an Annularia with small, linear-lanceolate leaves); non pl. 91, fig. 3 (= Asterophyllites sp. indet.).

p 1980 Annularia stellata, Zodrow and McCandlish, pl. 94, figs. 1, 2 (longer leaves); non pl. 95, fig. 1 (= Annularia stopesiae sp. nov.); non pl. 95, fig. 2 (= Annularia inflata).

p 1987 Annularia fertilis, Tenchov, p. 39, pl. XII, figs. 9-12; pl. XIII, figs. 1, 2; non pl. XIII, fig. 6 (= Annularia latifolia).

p 1991 Annularia jongmansi, Josten, pp. 77-78, Taf. 21, figs. 1-1a; Abb. 35; non Taf. 20, figs. 3-3a (= Annularia latifolia); non Abb. 34 (= Annularia latifolia).

T 1997 Annulariafertilis, Kvaček and Straková,p. 75, pl. 23, fig. 1 (photograph of Sternberg's holotype).

? 2006 Annularia, Falcon-Lang, pp. 42, 43, Fig. 9G (too fragmentary for a proper identification).

DESCRIPTION: Ultimate axes apparently smooth, about $1 \mathrm{~mm}$ wide, with internodes $25 \mathrm{~mm}$ apart, bearing overlapping verticils with 14-16 isophyllous leaves, united at the base so as to form an annulus. Leaves oblong, tapering gradually in the upper quarter length into an acute, mucronate apex. Dimensions: $9-17 \mathrm{~mm}$ long and up to 2 $\mathrm{mm}$ broad; length/breadth ratio $=4.5-8.5$. Vein straight and relatively broad, occupying about one fifth of the leaf width.

REMARKS: The holotype of Sternberg's Annularia fertilis, a species often included in the synonymy of Annularia stellata (e.g., by Zeiller 1888; Crookall 1969), is from Westphalian strata at Königsgruben, Upper Silesia, Poland. This specimen, reproduced photographically by Kvaček and Straková (1997, pl. 23, fig. 1), shows verticils composed of 14-16 isophyllous leaves, 7 to $14 \mathrm{~mm}$ long, with acute, mucronate apices. Canadian specimens assigned to Annularia fertilis fit this species perfectly, in particular those figured here in Figs. $2 \mathrm{a}$ and $2 \mathrm{e}$ (the latter slightly deformed tectonically).

COMPARISONS: Annularia latifolia possesses shorter, oblanceolate leaves, with maximum width in the upper third; it has a smaller length/breadth ratio than Annularia fertilis. In addition, Annularia latifolia shows a tendency towards anisophylly; this is not apparent in the leaf verticils of the holotype of Annularia fertilis. The late Stephanian Annularia spinulosa has longer, anisophyllous, lanceolate leaves (at 27-45 $\mathrm{mm}$ length, more than double the length of those of Annularia fertilis), with the greatest width just above the middle, and a sharply pointed apex. Annularia spinulosa has also more leaves (16 to 32) per verticil. Annularia sphenophylloides has smaller leaves than Annularia fertilis, and these are in anisophyllous verticils. Also, the leaves of Annularia sphenophylloides are spatulate and possess a markedly swollen, rounded, mucronate apex that is quite distinctive. The leaves of Annularia asteropilosa are also lanceolate, but are narrower, with a greater length/breadth ratio, and thus have a less pointed apex, apparently without a mucron.

STRATIGRAPHIC AND GEOGRAPHIC DISTRIBUTION: The holotype is from Westphalian strata of the Upper Silesian Basin, Poland. Gothan et al. (1959) recorded this species (misidentified as Annularia jongmansii) from Namurian C to Westphalian B of the Ruhr District, western Germany. Josten's (1991) specimen originated from Westphalian A (Langsettian) strata of the Ruhr District. Purkyňová (1962) figured specimens from upper Namurian B (Marsdenian) to Westphalian A (Langsettian) in the Ostrava-Karviná coalfield (Czech part of the Upper Silesian Basin). Tenchov (1987) figured this species from the Mogilište Formation, of Westphalian B (Duckmantian) age, in Bulgaria. Annularia fertilis is rarely recorded, but occurs widely.

OCCURRENCE IN THE MARITIME PROVINCES: SAINT John (New Brunswick): Bell (1944): locality 788 (three pieces without catalogue number - fragmentary); locality $1594=2577$ (GSC $5766-$ one specimen in the same rock sample as that figured in Bell 1944, pl. LXXVII, fig. 1 as Sporangites acuminata + nineteen specimens without GSC catalogue number - eighteen numbered as locality 2577 and one as 1594; see Figs. 2a, c-e). Fern Ledges (New Brunswick): New Brunswick Museum collection: NBMG 1757/1. McGill University Collection: $\mathrm{n}^{\circ}$ $3348+$ one piece without catalogue number. Sydney Basin (Nova Scotia): Zodrow and McCandlish (1980).

OCCURRENCE IN THE UNITED STATES: Indiana: Wood (1963). Michigan: Arnold (1949). 


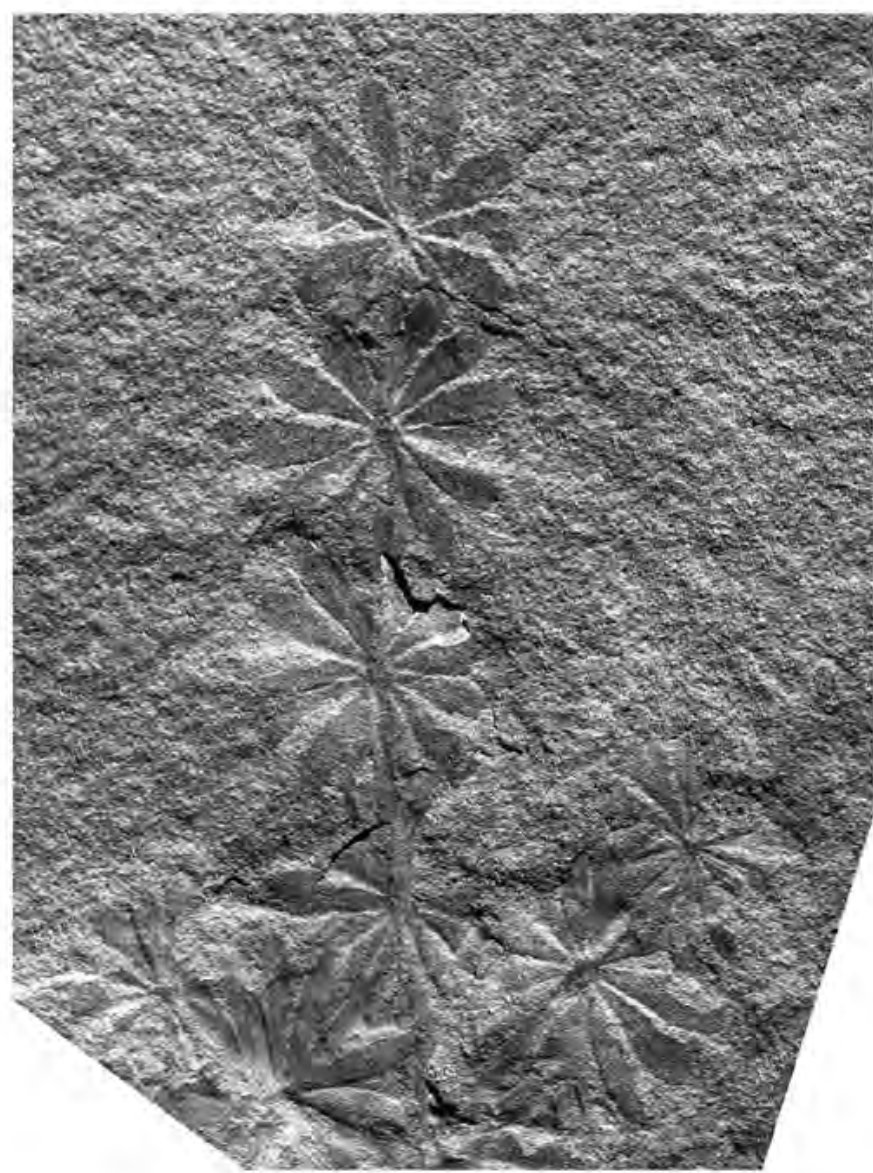

Figure 3. Annularia galioides (x 3). GSC 14916. Specimen figured previously by Bell (1966, pl. VII, fig. 3). Origin: Duck Cove, near Fern Ledges, Saint John, New Brunswick (locality 804). Repository: Geological Survey of Canada, Ottawa.

\section{Annularia galioides (Lindley and Hutton 1832) Kidston 1891}

(Fig. 3)

* 1832 Asterophyllites galioides Lindley and Hutton, pp. 79-80, pl. 25, fig. 2.

1868 Annularia sphenophylloides, Dawson, p. 444, Figs. $165 \mathrm{~B}, \mathrm{~B} 1$.

* 1881-84a Annularia Emersoni Lesquereux, pp. 50-51 (1881 - description); p. 725, pl. XCII, figs. 6-6a (1884a - illustration) (acc. to Abbott 1958).

* 1884a Annularia cuspidata Lesquereux, p. 725, pl. XCII, figs. 7-7a (acc. to Kidston 1893).

1886-88 Annularia microphylla, Zeiller, p. 392, pl. LX, figs. 3-4A.

$\$ 1891$ Annularia galioides (Lindley and Hutton) Kidston, p. 356.

1893 Annularia galioides, Kidston, pp. 317-318, pl. II, figs. 4-4a. p? 1906a Annularia latifolia, Matthew, pl. VII, fig. 3 (difficult to judge from the illustration); non pp. 125-126, pl. VII, fig. 2 (= Annularia fertilis).

1906a Annularia latifolia var. minor Matthew, p. 126, pl. VII, figs. 4-5.

1907a Annularia microphylla, Zalessky, p. 429, Tab. XVIII, fig. 3.

k 1936 Annulariagalioides, Walton, pp. 229-230, pl.31, fig. 11.

1949 Annularia sphenophylloides, Arnold, pl. XVI, fig. 4.

p 1958 Annularia asteris, Abbott, pl.35, fig. 7 (drawing); pl. 39, fig. 48; pl. 40, fig. 54; chart 2; non pp. 310-311, pl. 49, figs. 88-89 (= Annularia asteris).

1958 Annularia galioides, Abbott, pp. 311-312, pl. 40, fig. 52; chart 2.

1961 Annularia asteris, Leggewie and Schonefeld, pp. 29-30; Taf. 24, figs. 3-4; Taf. 26, figs. 7-8.

v 1966 Annularia latifolia, Bell, p. 16, pl. VII, fig. 3 (here as Fig. 3).

1966 Annularia, Gillespie et al.,pp. 64, 65, pl. 12, fig. 1.

1968 Annularia galioides, Basson, p. 57, pl. 5, fig. 1.

T 1969 Annularia galioides, Crookall, pp. 740-742, pl. CXXVII, fig. 6; text-fig. 216A (copy of Lindley and Hutton's figure of holotype); text-fig. 216B (same as Walton 1936, pl. 31, fig. 11).

1978 Annularia asteris, Gillespie et al., pp. 71, 74, 79, pl. 26, fig. 5.

? 1991 Annularia asteris, Josten, p. 86-87, Taf. 23, figs. 7-8a (fragmentary and poorly preserved); Abb. 41.

cf. 1996 Annularia asteris, Cross et al., pp. 406, 442, fig. 23-12.2.

cf. 1996 Annularia cf. A. galioides, Cross et al., pp. 406, 442, fig. 23-12.6.

cf. 2002 Annularia spicata, Blake et al., p. 292, pl. XVIII, fig. 6 .

Excludenda:

1936 Annulariagalioides (= Annulariaspicata), Moore et al., p. 11, fig. 6.7 (= Annularia spicata).

1957 Annularia galioides, Janssen, p. 87, Fig. 70 (here included, with doubt, in the synonymy of Annularia latifolia).

1963 Annularia galioides, Cridland et al., p. 70, pl. 18, fig. 17 (fragmentary; resembles Annularia spicata).

2016 Annularia galioides, Cleal et al., p. 3, Fig. 3g (= Annularia spicata).

DESCRIPTION: Axes longitudinally striate, $0.5-0.75 \mathrm{~mm}$ wide, with internodes $10-15 \mathrm{~mm}$ apart. Verticils on ultimate branches spaced at a little more than leaf length or slightly touching. Verticils with 10-12 leaves of approximately equal length, free, straight, oblanceolate, with maximum width above the middle and tapering basally and apically; blunt, obtuse apex. Dimensions: $4-6 \mathrm{~mm}$ long at $0.8-1.5 \mathrm{~mm}$ broad; length/breadth ratio $=4-5$. Central vein not visible. 
REMARKS: Annularia galioides was ascribed to Asterophyllites by Lindley and Hutton (1832), and recorded from lower Duckmantian strata at Barnsley, Yorkshire, England. Kidston (1891) transferred this speciesto Annularia. Lesquereux's Annularia cuspidata was placed in synonymy with Annularia galioides by Kidston (1893). Abbott (1958) did the same with Lesquereux's Annularia emersonii.

Here, we synonymize Matthew's Annularia latifolia var. minor with Annularia galioides. Matthew's variety was considered by Bell (1944) to fit the range of leaf length of Annularia latifolia; however, the verticils of the latter are anisophyllous and its leaves are widest in their upper third.

COMPARISONS: Annularia sphenophylloides has anisophyllous verticils with a larger number of leaves (12 to 18) that are spatulate, with a distinct mucron on the rounded apex. Although its leaves are also oblanceolate, Annularia latifolia has anisophyllous verticils with a larger number of leaves (12 to 16) that are longer and show a greater length/breadth ratio. Annularia microphylla has a similar number of leaves per verticil, but these are sickleshaped and narrow gradually from a maximum width at mid-length to a pointed apex. Its leaves are of similar size to those of Annularia galioides, but have greater length/ breadth ratio and are characterized by a rigid, slightly vaulted lamina. The upper Stephanian species Annularia spicata has smaller leaves (on average $2.5-3 \mathrm{~mm}$ long) that are stiffer, narrower, and have pointed apices.

STRATIGRAPHIC AND GEOGRAPHIC DISTRIBUTION: The holotype of Annularia galioides is from lower Duckmantian strata at Barnsley, Yorkshire, England. Crookall (1969) recorded this species from Westphalian B to Westphalian D (Duckmantian to Asturian) in Britain. Leggewie and Schonefeld (1961) recorded it from Westphalian A and lower Westphalian B (Langsettian and lower Duckmantian) of the Ruhr District, western Germany. According to Josten (1991), the species ranges from Langsettian to Bolsovian.

OCCURRENCE IN THE MARITIME PROVINCES: Cumberland Basin (Nova Scotia): Bell (1944): locality 1073 (GSC 9594 + GSC 9595 + GSC 9596 + GSC 9597 + GSC 9598 + GSC 9600 + GSC 9601 + one specimen with rubbedout catalogue number - all specimens poorly preserved); locality 1088 (GSC 10995 + GSC 10996 - part and counterpart). Wilson Collection (GSC, Ottawa): locality 810 (two pieces without catalogue number). FERN LEDGES (New Brunswick): Dawson (1868); Matthew (1906a); Bell (1944): locality 351 (one piece without catalogue number); Bell (1966): locality 804 (GSC 14916 - here Fig. 3).

OCCURRENCE IN THE UNITED STATES: MichigAN:
Arnold (1949). Missouri: Basson (1968). OHIO: Lesquereux (1881-1884a); Abbott (1958); Cross et al. (1996). WeST VIRGINIA: Gillespie et al. (1966); Gillespie et al. (1978); Blake et al. (2002).

\section{Annularia inflata Lesquereux 1870}

(Fig. 4; Figs. 5a-b)

* 1870 Annularia inflata Lesquereux, p. 423, pl. XX, figs. $1-2$, figs. 3-3b (drawings of leaf outline and cross section).

1870 Annularia longifolia, Lesquereux, pl. XX, figs. 4-4b (drawings of leaf and cross section).

p 1879-80 Annularia inflata Lesquereux, pp. 47-48, pl. II, fig. 2; pl. II, figs. 2bb (same as Lesquereux 1870, pl. XX, figs. 3-3b); non pl. II, fig. 1 (resembles Annularia radiata).

p 1880 Annularia longifolia, White, pp. 521-522, pl. XI, fig. 1; non pl. XI, fig. 2 (?).

p 1884b Annularia longifolia, Lesquereux, p. 44, pl. 7, fig. 1 (same as Lesquereux 1879, pl. II, fig. 2); non pl. 7, fig. 2 (Annularia radiata - same as Lesquereux 1879, pl. II, fig. 1).

v 1906a Annularia longifolia mutation Leavitti Matthew, pp. 124-125, pl. VII, fig. 1 (drawing) (assigned to Annularia stellata by Stopes 1914; here as Fig. 4).

v 1906b Annularia longifolia mutation Leavitti Matthew, pp. 396-397, pl. IX (upside down - photograph in Matthew 1906a, pl. VII, fig. 1; here as Fig. 4) (assigned to Annularia stellata by Stopes 1914).

1925 Annularia stellata, Noé, p. 13, pl. III, figs. 1-5.

p 1938 Annularia stellata forma mucronata, Bell, p. 85, pl. LXXXIX; pl. XCI, fig. 1; non pl. XC, fig. 1 (= Annularia stopesiae sp. nov.), non pl. XC, fig. 2 (difficult to judge from the illustration Annularia sp. indet.).

T 1940 Annularia stellata, Janssen, pp. 9-12, pl. I, fig. 1 (photograph of the holotype of Annularia inflata).

1957 Annularia stellata, Janssen, p. 84, fig. 67.

1957 Annularia radiata, Janssen, pp. 85-86, fig. 68.

kp1958 Annularia stellata, Abbott, pp. 321-326, pl. 35, fig. 1 (drawing); pl. 36, figs. 8-9 (drawings); pl. 41, fig. 58; pl. 43, figs. 62, 64 (cuticle); non pl. 49, fig. 87 (syntype of Carpannularia americana); chart 2.

? 1959 Annularia longifolia, Canright, pp. 21, 29, pl. 3, fig. 2 (figured at less than natural size and difficult to assess).

? 1959 Annularia stellata, Canright, pp. 21, 29, pl. 3, fig. 4 (at less than natural size).

1960 Annularia, Gillespie and Latimer, p. 42, pl. 6, fig. 4 (upside down).

1962 Annularia stellata, Gillespie and Clendening, p. 
130, pl. 4, fig. 6.

1966 Annularia stellata, Bell, p. 58, pl. XXVIII, fig. 6.

1966 Annularia, Gillespie et al., pl. 12, fig. 4 (same as Gillespie and Latimer 1960, pl. 6, fig. 4).

1968 Annularia stellata, Basson, pp. 58-59, pl. 5, fig. 2; pl. 6, fig. 1.

1969 Annularia stellata, Darrah, p. 172, pl. 37, fig. 1.

1978 Annularia stellata, Gillespie et al., pp. 70, 74, pl. 26, fig. 1.

p 1980 Annularia stellata, Zodrow and McCandlish, pl. 95, fig. 2; non pl. 94, fig. 1 (?), fig. 2 (resembles Annularia fertilis); non pl. 95, fig. 1 (= Annularia stopesiae sp. nov.).

1987 Annularia longifolia leavitti, Miller, p. 19, fig. 18 (upside down - same as Matthew 1906b, pl. IX).

p 2006 Annularia stellata, Wittry, fig. 1; non p. 92, fig. 2 (= Annularia latifolia).

DESCRIPTION: Ultimate axes up to $2.5 \mathrm{~mm}$ wide, with internodes $20-25 \mathrm{~mm}$ long, bearing slightly overlapping verticils. Verticils with 22-24 leaves, of unequal length, lying in the same plane as the axis and united at the base so as to form an annulus. Leaves oblanceolate, with convex margins and the greatest width in the upper third of leaf length; apex obtuse, with a mucron that is not always visible (frequently embedded in the matrix). Leaves are long and vary in size according to their position, the laterals (those placed perpendicular or subperpendicular to the axis) being longer than the lower and upper ones (more or less parallel to the axis); consequently, the verticils show an elliptical shape. Dimensions: varying between $20-25 \mathrm{~mm}$ and $30-45$ $\mathrm{mm}$ length at $2.50-4.25 \mathrm{~mm}$ width; length/breadth ratio $=8-10$. Vein clearly marked, straight, c. $0.3 \mathrm{~mm}$ wide.

REMARKS: Bell (1938) figured four specimens of this species from the Sydney Basin, Nova Scotia, as Annularia stellata forma mucronata. Two of these (Bell 1938, pl. XC, figs. 1-2) were included by Abbott (1958) in the synonymy of Annularia stellata; she attributed the other specimens (Bell 1938, pl. LXXXIX; pl. XCI, fig. 1) to Annularia mucronata. The holotype of the often-cited Annularia stellata (Schlotheim 1820, Taf. I, fig. 4 - possibly lost according to Kvaček and Straková 1997, p. 142) came from upper Stephanian strata of Kammerberg at Manebach, Thuringia, Germany. Barthel (2000) considered Annularia spinulosa (Sternberg 1821, Taf. 19, fig. 4 - photographically figured by Kvaček and Straková 1997, pl. 51, fig. 4, and Barthel 2000, Abb. 1a) as the correct name, with Annularia stellata as a synonym. Most authors now accept Barthel's point of view.

Annularia mucronata is a species introduced by Schenk (1883) from Permian strata in China. It is characterized by verticils with relatively long, spatulate, mucronate leaves. Most of the upper Westphalian and Stephanian specimens identified as Annularia mucronata from North America (e.g., Abbott 1958; Wood 1963) may be assigned to Annularia sphenophylloides.

Most comparable to Annularia mucronata are the specimens described by Elias (1931) as Carpannularia, a genus based on the presence of some reproductive structures (which Elias assumed to be seeds) that are attached to Annularia-type verticils. Abbott (1958) accepted the connection between these "seeds" and the leaf verticils and synonymized Elias's Carpannularia americana with Annularia stellata. However, Cridland (1968), who reexamined Elias's specimens, noticed that the "seeds" are detached, and not connected to the Annularia verticils. He proposed the synonymy of Carpannularia americana with Annularia mucronata, noting a similar leaf size, spatulate shape and mucronate apices. He also regarded the leaves figured by Elias as completely covered with "hairs".

We agree with Abbott that more than one species is represented in Bell's (1938) material, assigning two of Bell's specimens (pl. LXXXIX; pl. XCI, fig. 1) to Annularia inflata. The specimen shown in Bell's pl. XC, fig. 1 is here included in Annularia stopesiae sp. nov.; the fourth specimen can only be assigned as Annularia sp. indet.

Annularia inflata, a rarely recorded species, has been introduced by Lesquereux (1870) on the basis of two specimens from Mazon Creek, Illinois. Rather than providing a proper description, he noted the differences between his material and Annularia longifolia Brongniart. Lesquereux (1870) mentioned that Annularia inflata has oblanceolate, obtuse leaves with a subcylindrical or inflated shape and without a clearly marked vein. Annularia longifolia has flatter leaves with convex margins and a well marked vein. Lesquereux admitted the possibility that these two kinds of leaf might belong to a single species, and considered that the dimorphism might be due to some leaves being subaerial (corresponding to Annularia longifolia) and others aquatic (Annularia inflata). However, this is speculation. Janssen (1940, pl. I, fig. 1) published a photograph of Lesquereux's holotype under the name Annularia stellata.

Annularia longifolia is an invalid name, introduced by Brongniart (1828a) without description or illustration. Brongniart (1828a, p. 153) noted only the differences in leaf length in a verticil, and (on p. 156) placed Casuarinites stellatus Schlotheim and Bornia stellata Sternberg in synonymy with Annularia longifolia.

COMPARISONS: Annularia spinulosa (= Annularia stellata) has 16 to 32 leaves per verticil with 25-45 $\mathrm{mm}$ length. As in Annularia inflata, the lateral leaves are longer than the lower and upper ones. Annularia spinulosa leaves are widest just above their middle, and the apices are bluntly pointed. Annularia stopesiae sp. nov. also displays anisophyllous verticils with similar number of leaves, but these are linear-lanceolate, much longer (up to $85 \mathrm{~mm}$ ) and show a distinct cell pattern. 


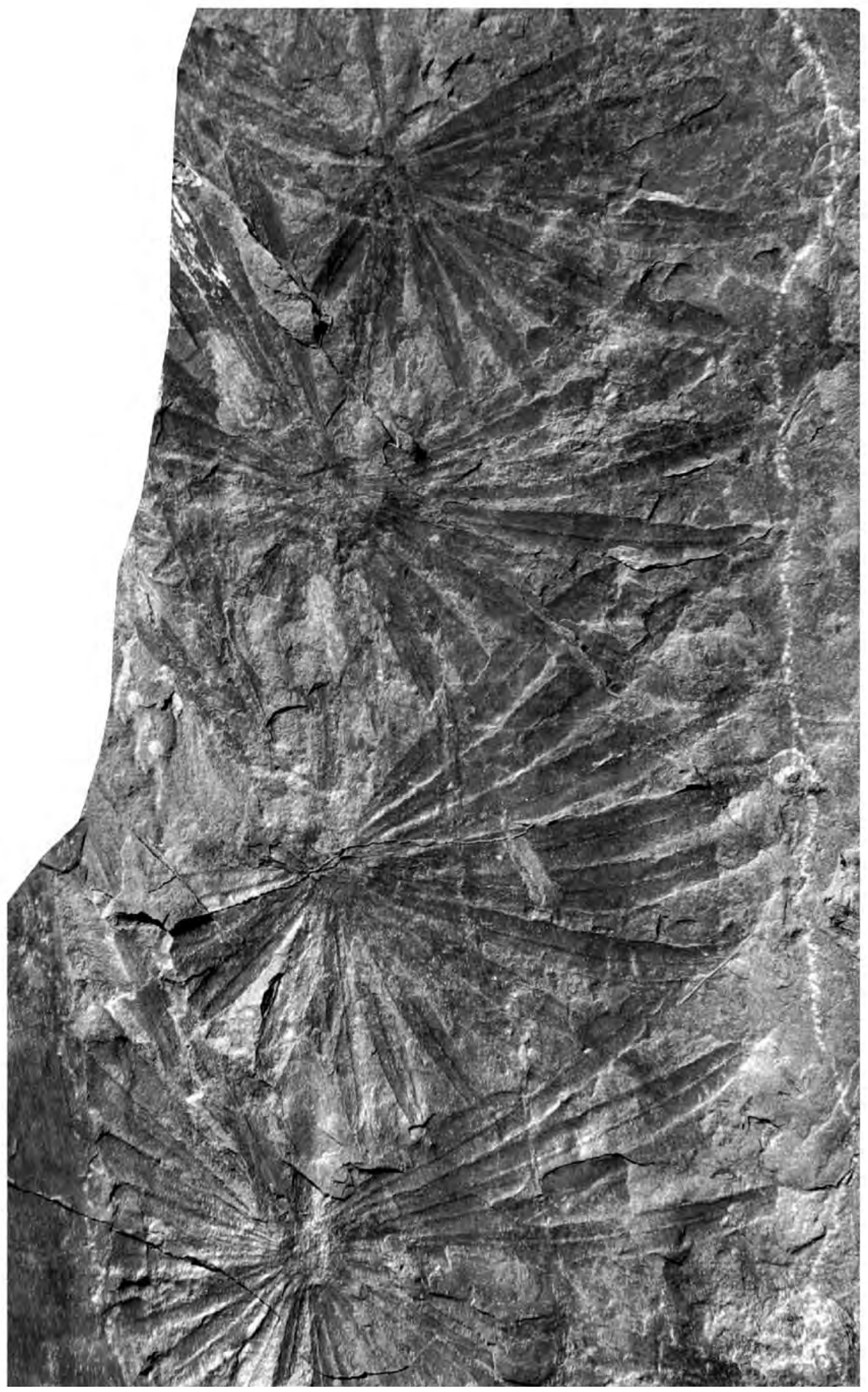




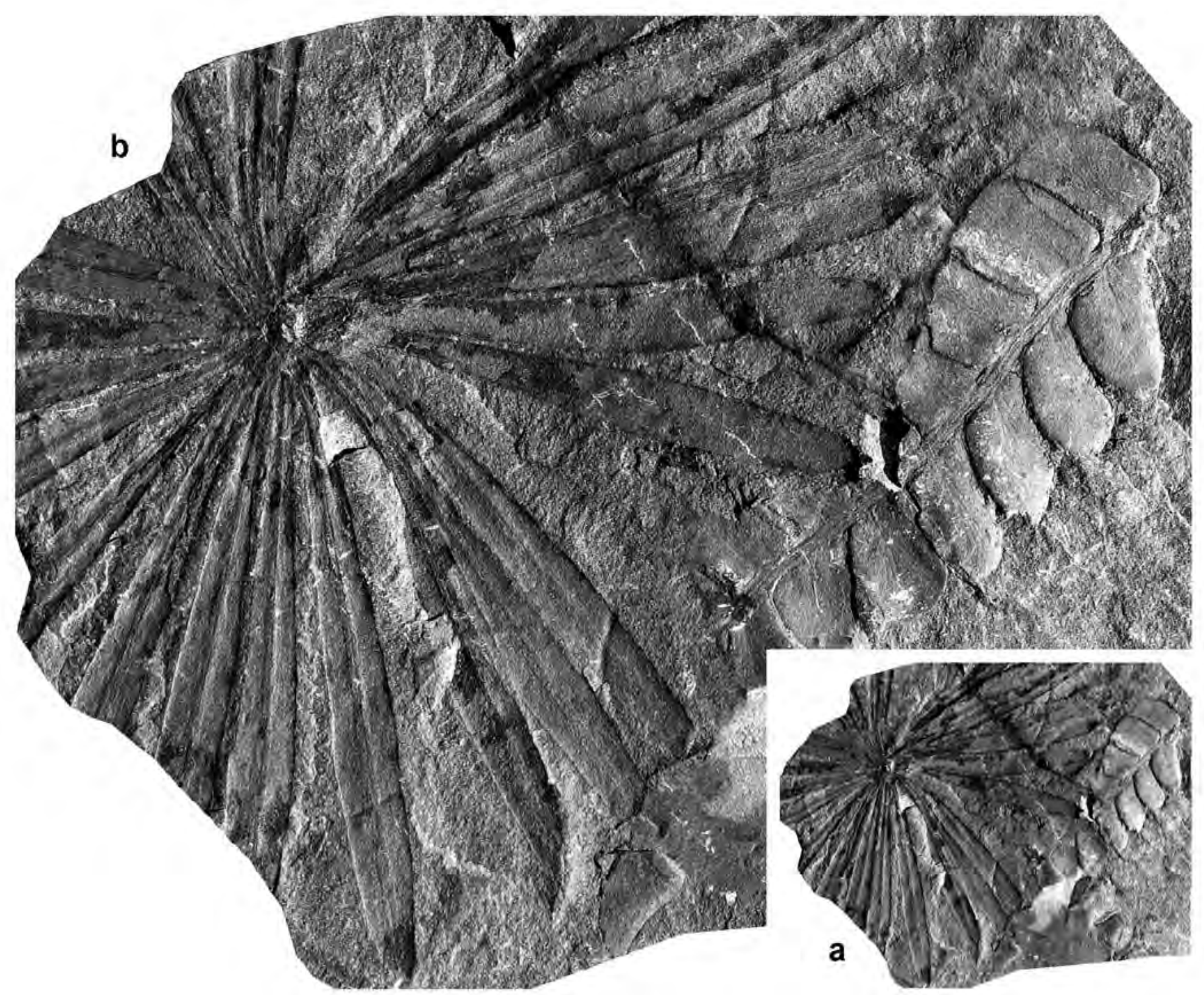

Figure 5. (a) Annularia inflata together with Laveineopteris polymorpha (x 1), NBMG 7649. Incomplete verticil showing the long, oblanceolate leaves characteristic of this species. Note the broad vein and small mucronate apex. Labelled as Annularia longifolia. Origin: Sunbury County, New Brunswick. Repository: New Brunswick Museum, Saint John. (b) Annularia inflata; enlargement (x 3) of specimen in Fig. 5 a.

STRATIGRAPHIC AND GEOGRAPHIC DISTRIBUTION: Lesquereux's (1870) type material as well as that figured by Noé (1925) and Darrah (1969) are from uppermost Asturian and/or lowermost Cantabrian strata at Mazon Creek, Illinois, U.S.A. White (1880) figured material from Asturian strata of the Shelburn Formation, Indiana. Canright's (1959) specimens are also from Indiana; these are from the Lower Block Coal, lower Brazil Formation of late Bolsovian age according to Bashforth and Nelson (2015).

Figure 4. (previous page) Annularia inflata (x 2). NBMG 3423. Specimen figured by Matthew (1906a, pl. VII, fig. 1 - as a drawing, and 1906b, pl. IX - photographically) as Annularia longifolia mutation leavittii. Note the variation in leaf size according to their position. Origin: Duck Cove, near Fern Ledges, Saint John, Lancaster, New Brunswick. Repository: New Brunswick Museum, Saint John. 
OCCURRENCE IN THE MARITIME PROVINCES: NEW Brunswick Museum COllection: NBMG 3423 (Saint John - specimen described and figured as Annularia longifolia mutation Leavittii in Matthew 1906a and 1906b - see Fig. 4) + NBMG 7649 (Sunbury County - together with Laveineopteris polymorpha and labelled as Annularia longifolia and Neuropteris sp.; here as Figs. 5a-b). Sydney BASIN (Nova scotia): Bell (1938): locality 513 (GSC 2269); locality 556 (GSC 3107). Bell (1966): locality 1331 (GSC 14906). Zodrow and McCandlish (1980).

OCCURRENCE IN THE UNITED STATES: ILLINOIS: Lesquereux (1870), Noé (1925), Janssen (1940), Janssen (1957), Darrah (1969), Wittry (2006). Indiana: White (1880), Canright (1959). Missouri: Basson (1968). Онiо: Abbott (1958). West Virginia: Gillespie et al. (1978).

Annularia latifolia (Dawson 1862) Kidston 1886 (Figs. 6a-b; Figs. 7a-k)

${ }^{*} \mathrm{p} 1862$ Asterophyllites latifolia Dawson, p. 311, pl. XIII, figs. 17a-b; non pl. XIII, fig. 17c (= Annularia fertilis).

p 1868 Asterophyllites latifolia Dawson, p. 538, Fig. 187A (same as Dawson 1862, pl. XIII, figs. 17a-b); non Fig. 187B (?); non Fig. 187D (= Annularia fertilis - same as Dawson 1862, pl. XIII, fig. 17c).

1869 Annularia Dawsonii Schimper, p. 350 (new name for Asterophyllites latifolia based on the reassignment to Annularia - see comments in Schimper 1874, p. 458).

p 1871 Asterophyllites latifolia, Dawson, p. 28, pl. V, figs. 50-51a; non fig. 52 (?); non fig. 53 (strobilus).

1884a Calamites ramifer?, Lesquereux, pp. 703-706, pl. XCI, figs. 4, 4a (acc. to White 1900, p. 898).

§ 1886 Annularia latifolia (Dawson) Kidston, p. 226.

p 1913 Annularia radiata, Jongmans and Kukuk, Taf. 16, fig. 5; non Taf. 16, figs. 1-4, 6 (= Annularia radiata). p 1913 Annularia stellata, Jongmans and Kukuk, Taf. 22, fig. 4; non Taf. 21, figs. 1-2 (= Annularia radiata).

1914 Annularia stellata, Kidston, p. 121, pl. IX, figs. 1-1a.

1914 Annularia sphenophylloides, Stopes, pp. 21-22, pl. V, fig. 7 (acc. to Bell 1944).

p 1914 Annularia latifolia [= A. stellata?], Stopes, pp. 23 -24, pl. VI, fig. 10 (photograph of Dawson 1871, pl. V, fig. 51), pl. VI, fig. 12 (fragmentary); pl. VII, fig. 13; non pl. VI, fig. 11 (= Annularia fertilis).

1934 Annularia radiata, Arnold, p. 187, pl. I, fig. 1.

${ }^{*}$ k1936 Annularia Jongmansi Walton, pp. 230-232, pl.31, fig. 12 (holotype - here as Fig. 6a), fig. 13 (here Fig. 6b), figs. 14-15 (enlargements of holotype); text-fig. 6.

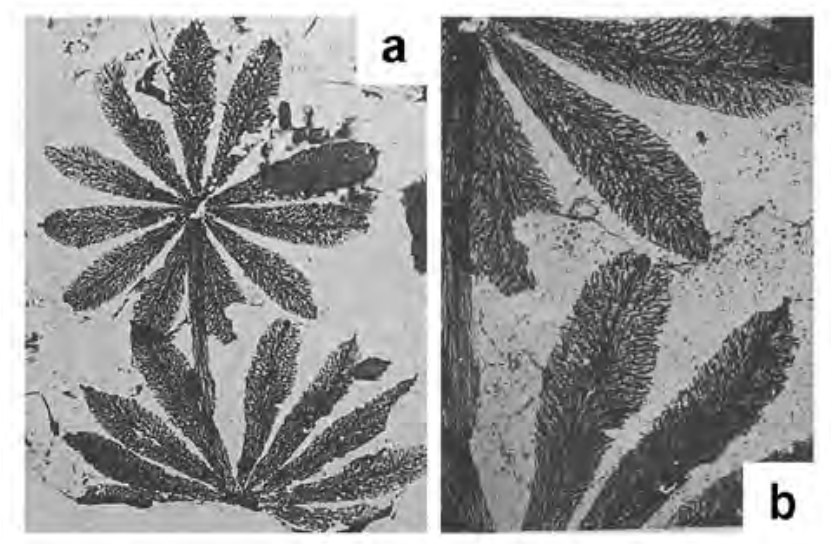

Figure 6. (a) Annularia latifolia (x 3). Reproduction of the type of Annularia jongmansii as figured by Walton (1936, pl. 31, fig. 12) (so as to show the identity with Dawson's species). Origin: Devon Tower Colliery, southwest of Tillicoultry, Clackmannanshire, Scotland. (b) Annularia latifolia. Detail of specimen in Fig. 6 a as figured by Walton (1936, pl. 31, fig. 13) showing the reticulate cell pattern of the lamina.

Figure 7. (next page) (a) Annularia latifolia (x 3). Origin: Saint John, New Brunswick (locality 810). Repository: Geological Survey of Canada, Ottawa. (b) Annularia latifolia (x 1). Origin: same as for Fig. 7a (locality 810). (c) Annularia latifolia. Enlargement (x 3) of specimen in Fig. 7b. (d) Annularia latifolia (x 1). NBMG 3413. Origin: Bed 1, Fern Ledges, Saint John, New Brunswick. Repository: New Brunswick Museum, Saint John. (e) Annularia latifolia. Enlargement (x 3) of the same specimen. Note the great similarity with Walton's specimen as reproduced in Figs. 6a-b herein. (f) Annularia latifolia (x 1). Specimen on the counterpart of that figured as Fig. 6g. Origin: Fern Ledges, Saint John, New Brunswick (locality 139). Repository: Geological Survey of Canada, Ottawa. (g) Annularia latifolia (x 1). Here the mucron is embedded in the rock, thus emphasizing the rounded aspect of the leaf apex. Origin: Fern Ledges, Saint John, New Brunswick (locality 139). Repository: Geological Survey of Canada, Ottawa. (h) Annularia latifolia. Enlargement (x 3) of the same specimen showing the faintly marked vein. (i) Annularia latifolia (x 1). Thin axis bearing anisophyllous leaf verticils. Origin: McCoy Head, East of Dickson Point, Saint John, New Brunswick (locality 828). Repository: Geological Survey of Canada, Ottawa. (j) Annularia latifolia. Enlargement (x 3) of specimen in Fig. 7i. (k) Annularia latifolia. Detail (x 6) of leaves in Fig. 7i showing the tiny mucron as well as the reticulate cell pattern of the lamina. 


1937 Annularia radiata forma karwinensis, Jongmans, p. 409, pl. 33, figs. 105-106.

1944 Annularia latifolia, Bell, p. 100.

? 1957 Annularia galioides, Janssen, p. 87, Fig. 70.

1958 Annularia latifolia, Abbott, pp. 313-314, pl. 35, fig. 3 (drawing); pl. 37, fig. 21 (drawing); chart 2.

1961 Annularia jongmansii, Leggewie and Schonefeld, pp. 28-29, Taf. 20, figs. 7-8; Taf. 26, figs. 4-6.

1968 Annularia radiata, Kotasowa, pp. 21-22 (excluding synonymy), Tab. III, fig. 5.

1987 Annularia jongmansii, Tenchov, p. 40, pl. XIII, figs. 3-4, fig. 5 (with doubt), figs. 7-9.

p 1987 Annularia fertilis, Tenchov, pl. XIII, fig. 6; non p. 39, non pl. XII, figs. 9-12 (= Annularia fertilis); non pl. XIII, figs. 1-2 (= Annularia fertilis).

p 1991 Annularia jongmansi, Josten, pp. 77-78, Taf. 20, figs. 3-3a, Abb. 34; non Taf. 21, figs. 1-1a (= Annularia fertilis); Abb. 35 (=Annulariafertilis).

v 1999 Annularia jongmansii, Álvarez-Vázquez, Figs. 2, 4 (name only).

p 2006 Annularia stellata, Wittry, p. 92, fig. 2; non fig. 1 (= Annularia inflata).

2007 Annularia stellata, Falcon-Lang and Miller, p. 240, Fig. 12 (same as Dawson 1871, pl. V, fig. 51, and Stopes 1914, pl. VI, fig. 10).

v 2010 Annularia jongmansii, Wagner and ÁlvarezVázquez, pp. 257, 266, 270.

Excludenda:

v 1966 Annularia latifolia, Bell, p. 16, pl. VII, fig. 3 (= Annularia galioides).

DESCRIPTION: Ultimate axes longitudinally striate, $0.8-1 \mathrm{~mm}$ wide, with internodes $10-12 \mathrm{~mm}$ apart, bearing verticils that touch or slightly overlap when spread out on the bedding plane. Verticils anisophyllous to a varying extent, with lateral leaves longer than those parallel to the axis. There are 12 to 16 leaves in a verticil, united at the base to constitute an annulus, oblanceolate, with maximum width in the upper third and gradually tapering to an obtuse, mucronate apex. Dimensions: 8-12 $\mathrm{mm}$ long at 1.25-1.9 $\mathrm{mm}$ (maximum) width; length/breadth ratio $\approx 6$. Vein straight, relatively broad, c. $0.6 \mathrm{~mm}$. In well-preserved adpressions an elongate, relatively coarse epidermal cell pattern, slightly oblique to the vein, is apparent.

REMARKS: Asterophyllites latifolia was introduced by Dawson in 1862 and transferred to Annularia by Schimper (1869), who renamed it (illegitimately) Annularia dawsonii. Kidston (1886) proposed the combination Annularia latifolia. Stopes (1914), who (incorrectly in our view) synonymized Annularia latifolia with the Stephanian species Annularia stellata, figured photographically the reasonably well-preserved specimens illustrated by Dawson in 1871. Abbott (1958) provided outline diagrams as well as a description and a brief history of what she regarded as Annularia stellata (but referring to specimens that in our view belong to Annularia latifolia).

Bell (1944) retained both Annularia latifolia and Annularia stellata as separate species. The Canadian species, Annularia latifolia, is identical to Annularia jongmansii, a species introduced and described more fully by Walton (1936) from lower Westphalian strata of the Midland Valley of Scotland. He seems to have been unaware of Annularia latifolia. Annularia jongmansii is characterized by anisophyllous verticils with lanceolate leaves showing a subrounded apex that includes a tiny mucron. Walton (1936) emphasized the presence of a relatively coarse, elongate epidermal cell pattern, which is also apparent in Annularia latifolia (Fig. 7k). These two species are identical in all respects and thus synonymous.

Bell (1944, p. 100) discussed Annularia latifolia, but did not provide an illustration. Practically all the localities cited by Bell (1944) are in New Brunswick, the only exception being locality 1362 at Joggins, Nova Scotia. However, the corresponding specimens (without catalogue number) are assigned here to Annularia microphylla. We note also that the specimen from New Brunswick figured by Bell (1966, pl. VII, fig. 3) as Annularia latifolia belongs to Annularia galioides (see Fig. 3).

COMPARISONS: Annularia sphenophylloides also has leaves with a prominent mucron, but these leaves are smaller, up to $12 \mathrm{~mm}$ long ( 6 to $8 \mathrm{~mm}$ on the average), spatulate and widest at the apex. Annularia galioides also has oblanceolate leaves, but these are smaller, up to $6 \mathrm{~mm}$ long, and have a smaller length/breadth ratio. In addition, leaves of Annularia galioides are of near-equal length in almost isophyllous verticils. Annularia microphylla has verticils with lanceolate and sickle-shaped leaves of equal length and stiffer aspect.

The leaves in Annularia microphylla are shorter than those of Annularia latifolia and have a smaller length/ breadth ratio. Verticils of Annularia fertilis have isophyllous leaf whorls, with oblong, longer leaves, with a greater length/breadth ratio. Leaves of Annularia asteropilosa are less pointed and have a greater length/breadth ratio.

STRATIGRAPHIC AND GEOGRAPHIC DISTRIBUTION: The synonymous Annularia jongmansii has been reported in Europe from upper Langsettian to lower Asturian strata. Walton's type is from lower Westphalian strata in Clackmannanshire, Scotland. Kidston's (1914) specimen (which he determined as Annularia stellata) is from upper Duckmantian strata of Staffordshire, England. Jongmans and Kukuk (1913) recorded material from Asturian sediments at Piesberg, western Germany. Kotasowa (1968) documented the species (as Annularia radiata) from Westphalian A (Langsettian) in the northeastern part of the Upper Silesian Coal Basin, Poland. Tenchov's (1987) material came from several horizons in Westphalian A, B and C (Langsettian, Duckmantian and Bolsovian) strata 
from the Dobrudža Basin, Bulgaria. Wagner and ÁlvarezVázquez (2010) recorded Annularia jongmansii from the upper Langsettian and the lower Bolsovian in the Peñarroya Basin, southwestern Spain, and from lower Asturian strata of the Sierra de la Demanda, Burgos province, northern Spain.

OCCURRENCE IN THE MARITIME PROVINCES: SAINT John (New Brunswick): Dawson (1862), Dawson (1868), Dawson (1871), Stopes (1914), Bell (1944), Abbott (1958), Falcon-Lang and Miller (2007). Wilson COLLECTION (Geological Survey Canada, Ottawa): locality 136 (136B); locality 139 (139 - together with Calamites sp. + 139a here Figs. $7 f$ and Figs. $7 g-h+139 b+139 c+139 d)$; locality 810 (three pieces without catalogue number - here Figs. $7 \mathrm{a}-$ c; together with Annularia galioides); locality 828 (198b here Figs. 7i-k); locality 2254 (one piece without catalogue number). New Brunswick Museum Collection: NBMG $3411+3412 / 1$ + NBMG 3413 (here Figs. 7d-e) + NBMG 3416 .

OCCURRENCE IN THE UNITED STATES: ILLINOIS: Janssen (1957). Michigan: Arnold (1934). OHio: Abbott (1958). Pennsylvania: Lesquereux (1884a), Wittry (2006). WEST ViRgINIA: Jongmans (1937).

\section{Annularia microphylla Sauveur 1848}

(Fig. 8)

* 1848 Annularia microphylla Sauveur, pl. LXIX, fig. 6.

T 1913 Annularia microphylla, Jongmans and Kukuk, Taf. 21, fig. 10 (copy of Sauveur 1848).

1914 Annularia microphylla, Kidston, pp. 172-173, pl. X, figs. 1-3a.

* 1949 Asterophyllites vernensis Arnold, pp. 182-183,pl. XVI, figs. 6-9.

1957 Annularia microphylla, Gothan and Remy, p. 53, Abb. 43.

1958 Annularia vernensis, Abbott, pp. 326-327, pl. 37, fig. 24 (drawing - copy in Boureau 1964, textfig. 166); chart 2.

1959 Annularia microphylla, Gothan et al., p. 51, Taf. 16, fig. 1 (same as Gothan and Remy 1957, Abb. 43).

1961 Annularia microphylla, Leggewie and Schonefeld, p. 30, Taf. 24, figs. $6,7$.

T 1969 Annularia microphylla, Crookall,pp. 742-744,pl. CXVII, fig. 2; pl. CXXVIII, figs. 4-5a; text-fig. 217 copy of Sauveur 1848).

1969 Annularia microphylla, García-Loygorri and Ortuño Aznar, pp. 845, 859, Fotos 19-19a.

$\mathrm{v}$ ?1971 Annularia microphylla, Wagner in Moore et al., p. 321, pl. 8, fig. 27 (fragmentary; Wagner and Álvarez-Vázquez 2010 compared with a sterile bract whorl of Calamostachys).

p 1978 Annularia radiata, Gillespie et al., pl.27, figs. 2, 6;

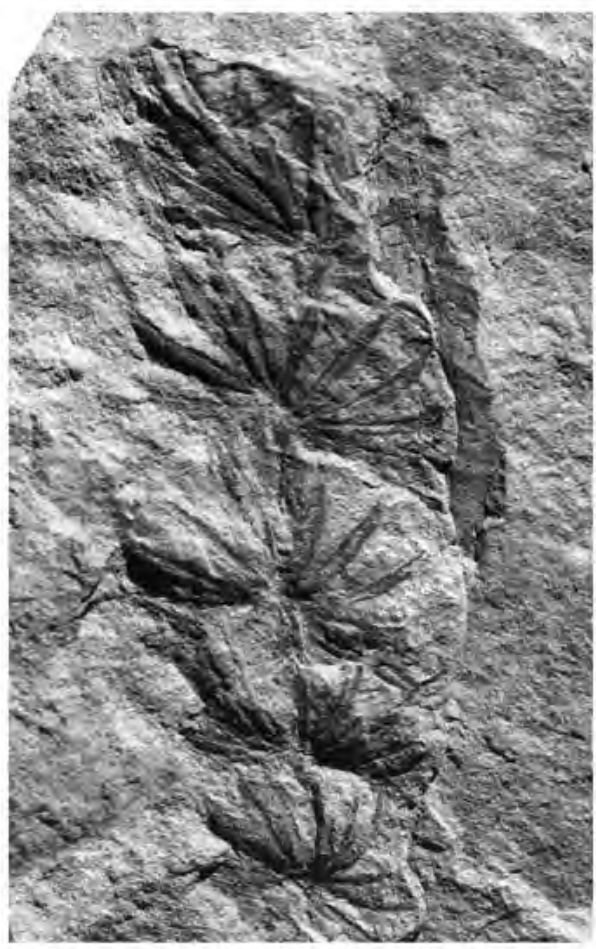

Figure 8. Annularia microphylla (x 3). Very similar specimen to that figured by Crookall (1969, pl. CXXVIII, figs. 4-5a) from the lower Westphalian of England. Origin: East Apple River, Joggins (locality 1362; without catalogue number). Repository: Geological Survey of Canada, Ottawa.

non pp. 70, 74, 80, pl. 26, fig. 8 (= Annularia ramosa?); non pl. 27, fig. 1 (= Annularia radiata).

1991 Annularia microphylla, Josten, pp. 80-81, Taf. 22, figs. 3-5a; Abb. 37.

2010 Annularia microphylla, Wagner and ÁlvarezVázquez, p. 257.

DESCRIPTION: Ultimate axis c. $0.75 \mathrm{~mm}$ wide, with internodes $4.5-5 \mathrm{~mm}$ long bearing verticils that touch or slightly overlap. Verticils with 12 leaves of equal length, lanceolate and sickle-shaped, gradually narrowing from maximum width at the middle to a pointed apex. Lamina relatively thick, slightly vaulted. Dimensions: $5-6 \mathrm{~mm}$ long at $0.5-0.6 \mathrm{~mm}$ width; length/breadth ratio $=10$. Vein straight, immersed in the lamina, and occupying one third of leaf width.

REMARKS: The description given here is based on a single specimen from Joggins, Nova Scotia. It was not described by Bell, although part of his 1911 collection. Even though fragmentary (only $30 \mathrm{~mm}$ ), it shows the sickle-shaped leaves, with a thick, vaulted lamina that is characteristic of Annularia microphylla. This species 
has often been regarded as conspecific with either Annularia galioides (e.g., Kidston 1891; Jongmans 1911) or Annularia spicata (Potonié 1893), but these three species can be differentiated without too much difficulty (see under Comparison) and have quite different ranges.

We regard Asterophyllites vernensis, described by Arnold (1949) from Grand Ledge, Michigan, as a synonym of Annularia microphylla. Arnold pointed out that the leaves of Asterophyllites vernensis are curved and laterally imprinted, as in Asterophyllites. Indeed, he compared Asterophyllites vernensis with Asterophyllites grandis, noting broader leaves in Asterophyllites vernensis. Arnold's species was transferred to Annularia by Abbott (1958). Although Abbott maintained Annularia vernensis as a separate species, she noted its close resemblance to Annularia galioides.

COMPARISONS: Annularia microphylla is distinctive, easily identified by its leaf shape and a thick lamina. It shows a superficial resemblance to Annularia galioides, but the oblanceolate leaves of the latter are flat and straight.

Annularia spicata has smaller, oblong leaves, with pointed apices; there are also fewer leaves per verticil in Annularia spicata.

STRATIGRAPHIC AND GEOGRAPHIC DISTRIBUTION: Annularia microphylla is rarely cited. The holotype is from the lower Westphalian of Belgium. Kidston (1914) and Crookall (1969) recorded this species from the Westphalian A and lower Westphalian B (Langsettian and lower Duckmantian) in Britain. Gothan and Remy (1957), Gothan et al. (1959), Leggewie and Schonefeld (1961), and Josten (1991) record the same range for this species from the Ruhr District, western Germany. GarcíaLoygorri and Ortuño Aznar (1969) figured Annularia microphylla from Langsettian strata of the Villanueva del Río y Minas coalfield, Sevilla province, southwestern Spain.

OCCURRENCE IN THE MARITIME PROVINCES: Cumberland Basin (Nova Scotia): Bell's collection 1911: locality 1362 (one piece without catalogue number).

OCCURRENCE IN THE UNITED STATES: MiCHIGAN: Arnold (1949); Abbott (1958). West Virginia: Gillespie et al. (1978).

\section{Annularia pseudostellata Potonié 1899}

(Figs. 9a, 9d-e)

* 1899 Annularia pseudostellata Potonié, pp. 200-201, Abb. 196 (copy in Jongmans 1911, p. 251, Fig. 204).

p 1906a Annularia acicularis, Matthew, p. 127, pl. V, fig. 1 (figured upside down - here as Fig. 9e); non pl. V, figs. 2-3 (= Asterophyllites lindleyanus).

1913 Annularia pseudostellata, Jongmans and Kukuk, Taf. 21, fig. 3, fig. 4 (upside down).

1934 Sphenophyllum myriophyllum, Arnold, p. 184, pl. VI, fig. 5; pl. VII, fig. 11 (cf.).

1957 Annularia pseudostellata, Guthörl, pp. 5, 7, Taf. 7, fig. 4; Taf. 8, fig. 9.

1959 Annularia pseudo-stellata, Remy and Remy, p.79, Abb. 59.

v 1966 Annularia acicularis, Bell, p. 12, pl. V, fig. 14 (here Fig. 9d).

1966 Annularia pseudostellata, Bell, p. 40, pl. XIX, fig. 6.

1977 Annulariapseudo-stellata, Remy and Remy, p. 371, Bild 226a-b (same as Remy and Remy 1959).

1989 Annularia pseudostellata, Laveine, pp. 49-50, pl. 16 , figs 4 , 4a; text-figs $40 \mathrm{~A}-\mathrm{B}$.

Excludenda:

1962 Annularia pseudostellata, Bell, pp. 50-51, pl. XLV, fig. 2 (= Annularia ramosa); pl. XLV, fig. 5 (= Annularia radiata); pl. XLVII, fig. 2 (= Asterophyllites sp.); pl. XLVII, fig. 3 (= Asterophyllites sp. indet.).

1978 Annularia pseudostellata, Gillespie et al., p. 74, pl. 26, fig. 2 (here included, with doubt, in the synonymy of Annularia stopesiae sp. nov.).

DESCRIPTION: Ultimate axes longitudinally striate, 1-2 $\mathrm{mm}$ wide, with internodes 9-14 $\mathrm{mm}$ apart bearing verticils flattened in the same plane as the axis, each with 10-14 leaves that overlap slightly. Leaves linear, narrow, of uniform size, with $20-25 \mathrm{~mm}$ long (incomplete) at $0.4-0.5 \mathrm{~mm}$ width; length/breadth ratio $\approx 50$. Lamina thick, vaulted. No vein. visible.

Figure 9. (next page) (a) Annulariapseudostellata (x3). GSC 283a. Origin: cutting east of Riversdale, Colchester County, Nova Scotia (locality 208). Repository: Geological Survey of Canada, Ottawa. (b) Annularia ramosa (x 6). GSC 9322. Specimen figured as Annularia aculeata by Bell (1944, pl. LX, figs. 3-4). Origin: Inverness County, Cape Breton Island, Chimney Corner area, shore about $1 \mathrm{~km}$ north of old coal mine (locality 1420). Repository: Geological Survey of Canada, Ottawa. (c) Annularia radiata (x 1). Copy of the synonymous Asterophyllites lentus as figured by Matthew (1906a, pl. V, fig. 7). Origin: Bed 2, Fern Ledges, Saint John, Lancaster, New Brunswick. (d) Annularia pseudostellata (x 3). GSC 14912. Figured as Annularia acicularis by Bell (1966, pl. V, fig. 14). Origin: unspecified location in a borehole in the Springhill area, Nova Scotia (locality 666). Repository: Geological Survey of Canada, Ottawa. (e) Annularia pseudostellata (x3). NBMG 7008/1. Figured (upside down) as Annularia acicularis by Matthew (1906a, pl. V, fig. 1). Origin: Bed 1, Fern Ledges, Saint John, Lancaster, New Brunswick. Repository: New Brunswick Museum, Saint John. 


COMPARISONS: Annularia radiata has shorter, linearlanceolate leaves with a smaller length/breadth ratio than those of Annularia pseudostellata. Annularia stopesiae sp. nov. is anisophyllous, with longer lateral leaves. This species also has more leaves in a verticil (20-24); these are longer and wider than those of Annularia pseudostellata.

STRATIGRAPHIC AND GEOGRAPHIC DISTRIBUTION: Annularia pseudostellata has been rarely recorded, but is apparently widespread. It occurs in lower Bolsovian to Asturian strata.

OCCURRENCE IN THE MARITIME PROVINCES: Cumberland Basin (Nova Scotia): locality 208 (GSC 283a - unpublished specimen from Ami collection, 1897; here as Fig. 9a). Bell (1966): locality 666 (GSC $14912-$ here Fig. 9d); locality 1039 (GSC 9061 + GSC 9063). New BRUNSWICK: locality 650 (six unpublished specimens without catalogue numbers). Sydney BAsin (Nova Scotia): Bell (1966): locality 1172 (GSC 14908). New BRUNSwiCK Museum Collection: NBMG 7008/1 (here Fig. 9e).

OCCURRENCE IN THE UNITED STATES: Michigan: Arnold (1934).

Annularia radiata (Brongniart 1822) Sternberg 1825 (Figs. 9c; Fig. 10)

* 1822 Asterophyllites radiatus Brongniart, pp. 210, 235, 239, pl. II, figs. 7a-b.

$\$ 1825$ Annularia radiata (Brongniart) Sternberg, p. 31.

* 1833 Asterophyllites foliosa Lindley and Hutton, pp. 77-78, pl. 25, fig. 1 (acc. to Kidston 1886, p. 44).

* 1848 Annularia asterophylloïdes Sauveur, pl. LXVII, fig. 1 (acc. to Zeiller 1888).

1848 Annularia radiata, Sauveur, pl. LXVII, fig. 2.

* 1862 Asterophyllites acicularis Dawson, p. 310, pl. XIII, figs. 16a-b (Dawson compared with Lindley and Hutton's Asterophyllites foliosa) (acc. to Lesquereux 1880).

1868 Asterophyllites acicularis Dawson, pp. 537-538, 555, Fig. 194H.

* 1871 Asterophyllites lenta Dawson, p. 29, pl. V, figs. 60-60a (acc. to Stopes 1914).

p 1886-88 Annularia radiata, Zeiller, pp. 394-398, pl. LIX, fig. 8 (together with Calamostachys); pl. LXI, figs. 1-1A; non pl.LXI, figs. 2-2A (=Annularia fertilis).

1906a Asterophyllites lentus, Matthew, p. 122, pl. V, fig. 5 (same as Dawson 1871, pl. V, fig. 60), fig. 6 (leaf), fig. 7 (copied here as Fig. 9c).

1907b Annularia radiata, Zalessky, p. 369, Tab. XIII, figs. $11 \mathrm{~A}-\mathrm{B}$.

p 1910 Annularia radiata, Renier, pl. 51; non pl. 52 (= Annularia galioides).
Tp 1911 Annulariaradiata, Jongmans, p.252, text-figs.206, 208 (copy of Brongniart's holotype figure); non text-fig. 207 (= Annularia ramosa and Calamostachys sp.); non text-fig. 209 (= Annularia fertilis).

p 1913 Annularia radiata, Jongmans and Kukuk, Taf. 16, figs. 1-4, 6; non Taf. 16, fig. 5 (= Annularia latifolia).

p 1913 Annularia stellata, Jongmans and Kukuk, Taf. 21,

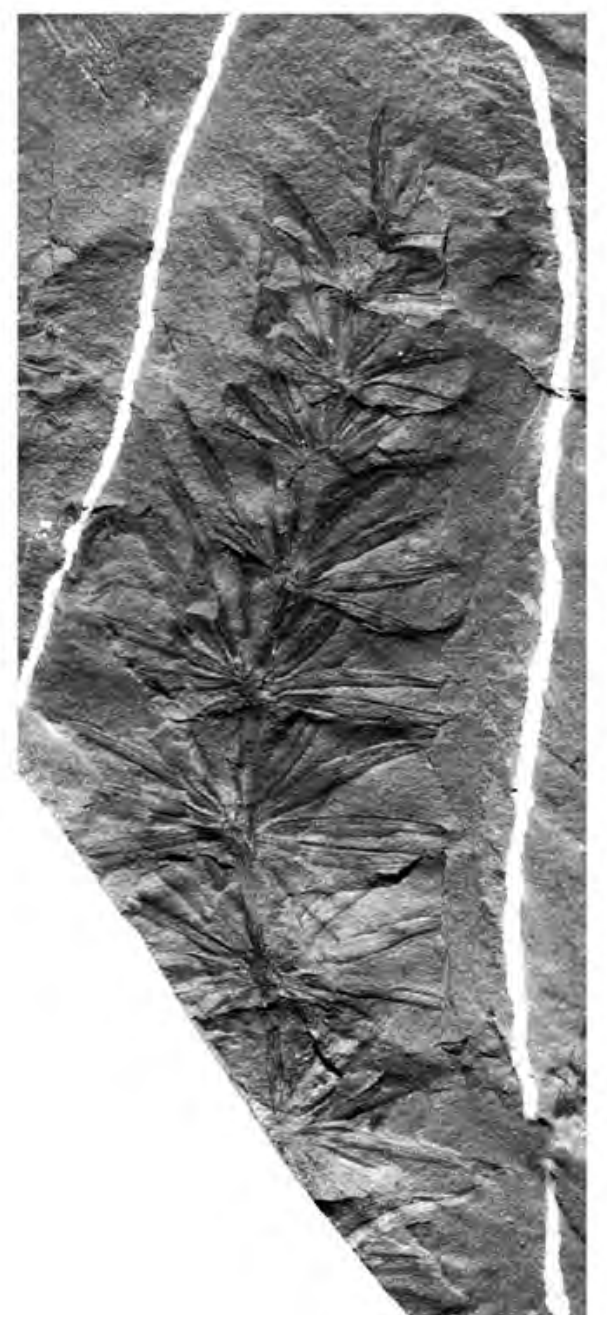

Figure 10. Annularia radiata (x 3). GSC 9303. Figured by Bell (1944, pl. LXIII, fig. 3) as Annularia acicularis. Origin: McCoy Head at Doctor Brook, near Saint John, New Brunswick (locality 628). Repository: Geological Survey of Canada, Ottawa. 
figs. 1, 2; non Taf. 22, fig. 4 (= Annularia latifolia).

1914 Asterophyllites sp. (= Annularia radiata?), Stopes, pp. 20-21, pl. IV, fig. 5 (photograph of Dawson 1871, pl. V, fig. 60).

1928 Annularia radiata, Jongmans, p. 19, pl. 10, fig. 3.

1925 Annularia radiata, Noé, p. 13, pl. IV, fig. 2; pl. V, fig. 1.

1932 Annularia radiata, Jongmans, p. 5, Fig. 9.

p 1937 Annularia radiata, Jongmans, pp. 406, 409, pl. 26, fig. 71 (fragmentary and poorly figured); pl. 33, fig. 104; non p. 405, pl. 25, fig. 68 (= Annularia ramosa).

? 1938 Annularia radiata, Bell, p. 85, pl. LXXXVIII, fig. 2 . vp 1944 Annularia acicularis, Bell, p. 101, pl. LVIII, fig. 5; pl. LX, fig. 6; pl. LXIII, fig. 3 (here as Fig. 10); pl. LXIV, fig. 5; pl. LXV, fig. 2; pl. LXIX, fig. 5; non pl. LVIII, fig. 2 (Calamites node).

1952 Annularia radiata, Novik, p. 148, Tab. XVI, figs. $3,4$.

? 1958 Annularia radiata, Abbott, pp. 317-319, pl. 41, fig. 56 ; chart 2.

? 1958 Annularia radiata, Langford, p. 40, fig. 41.

1959 Annularia radiata, Gothan et al., pp. 45-47, Taf. 13, figs. 1-3.

1960 Annularia, Gillespie and Latimer, p. 28, pl.6, fig. 2.

1961 Annularia radiata Brongniart forma, Leggewie and Schonefeld, p. 28, Taf. 24, figs. 1, 5.

1961 Annularia radiata f. hirsuta, Leggewie and Schonefeld, pp. 27-28, Taf. 23, figs. 1-4.

p 1962 Annulariapseudostellata, Bell, pl.XLV, fig. 5; non pp. 50-51, pl. XLV, fig. 2 (= Annularia ramosa); non pl. XLVII, fig. 2 (= Asterophyllites sp.); non pl. XLVII, fig. 3 (= Asterophyllites sp.).

? 1966 Annularia radiata, Bell, p. 56, pl. XXVII, fig. 6.

1966 Annularia, Gillespie et al., p. 21, pl. 12, fig. 2 (same as Gillespie and Latimer 1960, pl. 6, fig. 2).

p 1978 Annularia radiata, Gillespie et al., pp. 70, 74, 80, pl. 27, fig. 1 (same as Gillespie and Latimer 1960, pl. 6, fig. 2 and Gillespie et al. 1966, pl. 12, fig. 2); non pl. 26, fig. 8 (= Annularia ramosa?); non pl. 27, figs. 2, 6 (= Annularia microphylla).

1981 Annularia radiata, Cleal, p. 15, pl. 5, fig. 1.

1981 Annularia radiata, DiMichele and Dolph, pl. 2, fig. 18.

1982 Annularia radiata, Bassett and Edwards, p. 32 (right).

1982 Annularia radiata, DiMichele in Eggert and Phillips, pl. 2, fig. G (same as DiMichele and Dolph 1981, pl. 2, fig. 18).

p 1987 Annularia fertilis, Tenchov, pl. XII, figs. 9-12; pl. XIII, fig. 6 (?); non p. 39, pl. XIII, figs. 1-2 (= Annularia fertilis).

p 1987 Annularia radiata, Tenchov, p. 41, pl. XIV, fig. 5, 6 (?), figs. 7-8, figs. 11-14; non pl. XIV, fig.
9 (= Asterophyllites ?); non pl. XIV, fig. 10 (= Annularia ramosa).

1988 Annularia radiata, Cleal, p. 102, Fig. 1 (same as Cleal 1981).

1991 Annularia radiata, Josten, pp. 74-75, Taf. 18, figs. 2-3; Taf. 19; Abb. 32.

p 1991 Annularia jongmansi, Josten, Taf. 21, figs. 1, 1a; Abb. 35; non pp. 77-78, Taf. 20, figs. 3-3a (= Annularia latifolia); non Abb. 34 (= Annularia latifolia).

1994 Annularia radiata, Thomas and Cleal, p. 20, Fig. 2B.

2006 Annularia radiata, Wittry, p. 90, Figs. 1-4.

2009 Annularia radiata, Libertin et al., pl. VI, fig. 1.

v 2010 Annularia radiata, Wagner and Álvarez-Vázquez, pp. 257, 266, 268, 270.

? 2014 Annularia sp. cf. A. acicularis, Bashforth et al., pp. 243, 245, pl. 1, fig. 3 (fragmentary and poorly preserved).

Excludenda (including Annularia acicularis):

1871 Asterophyllites acicularis Dawson, pp. 28-29, pl. V, figs. 54 (= Asterophyllites grandis), figs. 54a54c (leaves of Annularia sp. indet.); pl. V, figs. 55-56 (strobili); pl. V, fig. 57 (stem).

p 1906a Annularia acicularis, Matthew, p. 127, pl. V, fig. 1 (= Annularia pseudostellata); pl. V, figs. 2-3 (= Asterophyllites lindleyanus).

1914 Asterophyllites acicularis (= A. equisetiformis), Stopes, pp. 19-20, pl.IV, fig. 6 (= Asterophyllites grandis - same as Dawson 1871, pl. V, fig. 54).

1934 Annularia radiata, Arnold, p. 187, pl. I, fig. 1 (= Annularia latifolia).

1957 Annularia radiata, Janssen, p. 85, Fig. 68 (= Annularia inflata).

1962 Annularia radiata, Gillespie and Clendening, p. 125, pl. 4, fig. 4 (= Annularia sp., anisophyllous verticils with leaves showing a more acute apex than in Annularia radiata).

1963 Annularia radiata, Cridland et al., p. 70, pl. 18, fig. 16 (= Annularia carinata).

1963 Annularia radiata, Wood, pp. 40-41, pl. 3, fig. 8 (= Annularia cf. fertilis).

1968 Annularia acicularis, Basson, p. 56, pl. 4, fig. 2 (to be compared with Annularia ramosa or Asterophyllites sp.).

1976 Annularia acicularis, Oleksyshyn, p. 156, Figs. 7B-7D (= Asterophyllites sp. indet. - too fragmentary for a specific identification).

1977 Annularia radiata, Gastaldo, pp. 137, 144, Fig. 29 (difficult to judge from an illustration at less than natural size, but apparently showing smaller, broader leaves with a more rounded apex).

1980 Annularia radiata, Zodrow and McCandlish, pl.91, fig. 1 (=Annulariafertilis), pl.91, figs. 2-3 
(= Asterophyllites?).

1982 Annularia radiata, Ash and Tidwell,pp. 245-246, Fig. 2 (=Asterophyllites sp.indet. - fragmentary).

1996 Annularia radiata, Cross et al., pp. 406, 442, Fig. 23-12.4 (difficult to judge from the illustration, but showing leaves with a broader lamina lamina and a subrounded apex).

DESCRIPTION: Ultimate axes longitudinally striate, c. $1-1.5 \mathrm{~mm}$ wide, with internodes $10-25 \mathrm{~mm}$ apart bearing verticils spread out on the bedding plane that touch but do not overlap. Verticils with 12 to 16 leaves, narrowly joint at the base, of almost equal length, linearlanceolate, broadest about the middle and tapering to an acute apex. Dimensions: 11-24 mm long at 1-1.5 $\mathrm{mm}$ width; length/breadth ratio $=11-16$. A longitudinal cell pattern is observed in some well-preserved leaves.

REMARKS: Annularia acicularis, here included in Annularia radiata, was introduced by Dawson (1862) as Asterophyllites acicularis; it was transferred to Annularia by White (1900). Bell (1944, p. 101) included Annularia acicularis in the synonymy of Asterophyllites lentus Dawson, a species that Stopes $(1914$, p. 20$)$ regarded as a probable synonym of Annularia radiata. Abbott (1958) distinguished Annularia acicularis from Annularia radiata by the presence of linear leaves in Annularia acicularis, as against the linear-lanceolate leaves and a greater length/ breadth ratio for Annularia radiata. She also noted that Annularia acicularis has anisophyllous leaf verticils, in contrast to the isophyllous verticils of Annularia radiata. However, these distinctions are blurred when Brongniart's and Dawson's original drawings are compared. Annularia acicularis has been ignored by European authors.

Most of the specimens that Bell (1944) assigned to Annularia acicularis have been available for reexamination. Six of these specimens (Bell 1944, pl. LVIII, fig. 5; pl. LX, fig. 6; pl. LXIII, fig. 3; pl. LXIV, fig. 5; pl. LXV, fig. 2; pl. LXIX, fig. 5) are included here in Annularia radiata. Another specimen (Bell 1944, pl. LVIII, fig. 2) represents a node of Calamites with stem leaves and thus cannot be assigned to Annularia. The specimen figured as Asterophyllites sp. (= Annularia radiata?) by Stopes (1914, pl. IV, fig. 5), after Dawson (1871), probably belongs also to Annularia radiata, but is too poorly preserved for a definitive identification. A specimen figured as Asterophyllites acicularis $(=$ Asterophyllites equisetiformis?) by Stopes (1914, pl. IV, fig. 6), after Dawson (1871), is here assigned to Asterophyllites grandis.

COMPARISONS: Annularia fertilis possesses isophyllous verticils with a similar number of leaves to that in Annularia radiata; however, these are oblong, with an acute, mucronate apex. They are also a little longer, and possess a smaller length/breadth ratio. Annularia latifolia has anisophyllous leaf verticils with smaller, oblanceolate leaves topped by an obtuse, mucronate apex. Its leaves are smaller, with a smaller length/breadth ratio. In well-preserved adpressions of this species, the presence of an elongate, relatively coarse epidermal cell pattern, slightly oblique to the vein, is distinctive. Annularia fimbriata has more leaves in a verticil (15 to 20 ) than does Annularia radiata. The leaves are shorter and have a smaller length/breadth ratio. A transfer preparation by Walton (1936) shows a shallow median groove extending from the leaf base up to near the sharply pointed apex; he also recorded slightly oblique rows of hairs. Annularia ramosa has fewer leaves in a verticil ( 8 to 12) than Annularia radiata; they are also shorter and have a smaller length/breadth ratio. Annularia isperichii, described by Tenchov (1987), has fewer leaves (9 to 12) per verticil; they are of similar size to those of Annularia radiata, but are more markedly lanceolate, with a pointed, mucronate apex.

STRATIGRAPHIC AND GEOGRAPHIC DISTRIBUTION: Annularia radiata occurs most commonly in upper Langsettian and Duckmantian strata. Although the provenance of the holotype is unknown (Brongniart 1822), that of Asterophyllites foliosa, a synonym, is from the lower Duckmantian Bensham coal seam, Jarrow Colliery, near Newcastle, northern England. Annularia asterophylloides, another synonym, came from an unknown horizon in the lower Westphalian of Belgium (Sauveur 1848). Josten (1991) recorded Annularia radiata as ranging throughout Westphalian A-C (Langsettian to Bolsovian), and disappearing in the lower Westphalian D (Asturian). Tenchov (1987) figured this species from Westphalian B (Duckmantian) strata in Bulgaria. Wagner and ÁlvarezVázquez (2010) recorded Annularia radiata from Langsettian to lower Asturian strata in the Iberian Peninsula.

OCCURRENCE IN THE MARITIME PROVINCES: Cumberland Basin (Nova Scotia): Bell (1944): locality 999 (GSC 8607 + GSC 9120 + GSC 9580 + one piece without catalogue number - all specimens poorly preserved). FerN Ledges, New Brunswick: Dawson (1862). Dawson (1868). Dawson(1871). Matthew(1906a).Stopes(1914):locality3340 of McGill University collection (holotype of Asterophyllites lentus - same as Dawson 1871 and Matthew 1906a). Bell (1944): locality 628 (GSC 9303 - here Fig. 10 + GSC 9314); locality 630 (GSC $9138+$ GSC 9356 + 9373). Bashforth et al. (2014). Minto CoAlfield (New Brunswick): Bell (1962): locality 1019 (GSC 835). Minas Basin (Nova Scotia): Bell (1944): locality 3106 (GSC 10281). Sydney BASIN (Nova Scotia): Bell (1966): locality 516 (GSC 14911).

OCCURRENCE IN THE UNITED STATES: ILLINOIS: Noé (1925); Langford (1958); Wittry (2006). OHIо: Abbott (1958). West Virginia: Jongmans (1937); Gillespie and Latimer (1960). 


\section{Annularia ramosa Weiss 1884}

(Fig. 9b)

* 1884 Annularia ramosa Weiss (= Ann. radiata Brong. neque Auct.), pp. 184-197, Taf. V, fig. 1 (together with Calamites ramosus = Calamites carinatus); Taf. VI, figs. 1, 5 (with Calamites ramosus); Taf. VIII, fig. 4 (with Calamites ramosus); Taf. X, fig. 1 (with Calamites ramosus); Taf. XX, fig. 1 (together with Calamites ramosus and Calamostachys ramosa).

p 1937 Annularia radiata, Jongmans, p. 405, pl. 25, fig. 68; non pp. 406, 409, pl. 26, fig. 71 (= Annularia radiata - poorly figured); pl. 33, fig. 104 (= Annularia radiata).

*vp1944 Annularia aculeata Bell, pp. 101-102, pl. LX, figs. 3-4 (here Fig. 9b); pl. LXV, fig. 1 (cf.); pl. LXVIII, fig. 4 (holotype); pl. LXIX, figs. 1-2; non pl.LXII, fig.2 (= Asterophyllites charaeformis); non pl. LXIII, fig. 4 (= Asterophyllites charaeformis); non pl. LXV, fig. 4 (= Asterophyllites charaeformis?); non pl. LXVI, fig. 1(= Annularia sp. - poorly preserved); non pl. LXVI, fig. 3 (= Asterophyllites grandis); non pl. LXVIII, fig. 1 (= Asterophyllites charaeformis - figured as Annularia aculeata and Asterophyllites charaeformis); non pl. LXIX, fig. 3 (poorly preserved, but resembling Asterophyllites);non pl. LXIX, fig. 6 (fragmentary - Asterophyllites sp.).

p 1962 Annularia pseudostellata, Bell, pl. XLV, fig. 2; non pp. 50-51, pl. XLV, fig. 5 (= Annularia radiata); pl. XLVII, fig. 2 (= Asterophyllites $\mathrm{sp}$.$) ;$ non pl. XLVII, fig. 3 (= Asterophyllites sp.).

1962 Annularia radiata, Purkyňová, p. 45, Tab.X, fig. 6.

1963 Annularia radiata, Němejc, p. 320, Tab. XXXV, fig. 2.

1965 Annularia ramosa, Stockmans and Willière, p. 16, pl. I, fig. 7.

? 1968 Annularia acicularis, Basson, p. 56, pl. 4, fig. 2 (poorly preserved).

? 1977 Annularia cf. vernensis, Leary and Pfefferkorn, p. 7, pl. 1, fig. 4 (might also be Asterophyllites sp.); text-figs. 4B-4C.

p 1978 Annularia radiata, Gillespie et al., pp. 70, 74, 80, pl.26, fig. 8; non pl. 27, fig. 1 (= Annularia radiata); non pl. 27, figs. 2, 6 (= Annularia microphylla).

1985 Annularia asteris, Gillespie and Rheams, pp. 194, 196, pl. I, fig. 2.

1985 Annularia asteris, Gillespie and Crawford, pp. 252, 255, pl. III, fig. 2.

1985 Annularia cf. acicularis, Lyons et al.,pp. 220, 222, 257, pl. VII, fig. c.
? 1987 Annularia asteris, Tenchov, p. 38, pl. XII, figs. 1-3.

p 1987 Annularia radiata, Tenchov, pl. XIV, fig. 10; non p. 41, pl. XIV, fig. 5 (= Annularia radiata), fig. 6 (?), figs. 7-8 (= Annularia radiata), figs. 11-14 (= Annularia radiata); non pl.XIV, fig. 9 (= Asterophyllites?).

p 1991 Annularia ramosa, Josten, pp. 75-77, Taf. 20, figs. 2-2a; Abb. 33 (drawing); non Taf. 20, fig. 1 (= Annularia asteris).

1991 Annularia aculeata, Josten, pp. 83-86, Taf. 23, figs. 4-6a; Abb. 40.

v 1995 Annularia ramosa, Álvarez-Vázquez, pp. 268-270, lám. 88, fig. 2; lám. 89, fig. 2; lám. 92, figs. 2-2a.

1996 Annularia asteris, Cross et al., pp. 406, 442, fig. 23-12.2.

1997 Annularia radiata, Purkyňová, p. 194, Tab. I, fig. 2 (same as Purkyňová 1962, Tab. X, fig. 6).

v 2010 Annularia ramosa, Wagner and Álvarez-Vázquez, pp. 257, 266.

Excludenda:

1976 Annularia aculeata, Oleksyshyn, p. 156, Fig. 7B (fragmentary - Asterophyllites sp. indet.).

DESCRIPTION. Penultimate axes straight, 2-2.25 $\mathrm{mm}$ wide. Ultimate axes oppositely inserted at right angles, c. $0.5-0.75 \mathrm{~mm}$ wide; internodes $20 \mathrm{~mm}$ apart, bearing verticils with 8 to 12 , widely spaced leaves all of similar length, linear-lanceolate, widely attached at the base and slightly pointed. Dimensions: $3.5-8 \mathrm{~mm}$ long at $0.15-0.3 \mathrm{~mm}$ wide; length $/$ breadth ratio $=23-26$. Vein not visible, obscured by a longitudinal cell pattern.

REMARKS: Bell (1944) included in Annularia aculeata specimens with verticils showing considerable variation in the number, size and shape of leaves. The holotype (Bell 1944, pl. LXVIII, fig. 4) shows second order branches with two fragmentary first order branches and one incomplete verticil that may be identified (a second is too poorly preserved), with 8 leaves, 3.5-4 mm long (three of these leaves show only the insertion). This specimen is a compression well enough preserved to show a longitudinal cell pattern. Very similar to the holotype is a well-preserved specimen from a locality (1420) in Inverness County, Cape Breton Island, Nova Scotia, showing widely spaced, small, slender, pointed leaves, fused at the base (Bell 1944, pl. LX, figs. 3-4; our Fig. 9b), all characters that accord with Annularia ramosa.

Several authors (e.g., Jongmans 1911; Abbott 1958; and Crookall 1969) regarded Annularia ramosa as a synonym of Annularia radiata. However, the holotype of Annularia radiata has a greater number of leaves per verticil (up to 16) than is the case for Annularia ramosa; they are also longer $(20-22 \mathrm{~mm})$, with a greater length/ breadth ratio. These two species are clearly different. 
COMPARISONS: Annularia galioides possesses oblanceolate leaves with an obtuse apex; maximum width occurs just above the middle, in contrast to the linearlanceolate, fleshier leaves with pointed apices of Annularia ramosa. Annularia radiata has more leaves per verticil (12-16); although these leaves, like those of Annularia ramosa, are linear-lanceolate and in isophyllous verticils, they are longer. Annularia asteris has stiff, narrow leaves with acuminate apices; verticils are smaller $(2-4.5 \mathrm{~mm}$ long and $0.20-0.25 \mathrm{~mm}$ width) than those of Annularia ramosa. Although Annularia microphylla has leaves similar in shape to those of Annularia ramosa, they are stiffer and curved, favouring adpression parallel to the axis.

STRATIGRAPHIC AND GEOGRAPHIC DISTRIBUTION: Annularia ramosa is fairly widespread and ranges from Namurian B to lower Bolsovian. The type material (Weiss 1884 ) is from lower Westphalian strata in Neurode (Nowa Ruda), Lower Silesia, Intrasudetic Basin, southwestern Poland. Josten (1991) records this species (as Annularia ramosa and Annularia aculeata) from upper Langsettian and lower Duckmantian strata in the Ruhr District in western Germany. Specimens figured by Tenchov (1978) from Bulgaria as Annularia asteris and Annularia radiata are from Namurian C (Yeadonian) and Westphalian A (Langsettian) strata. Stockmans and Willière (1965) recorded Annularia ramosa from Langsettian deposits at San Emiliano, León province, northwestern Spain. Wagner and ÁlvarezVázquez (2010) added a record from the Langsettian of La Camocha coal mine, near Gijón (Asturias province), northwestern Spain; they also recorded this species from upper Langsettian and lower Bolsovian strata of the Peñarroya Basin (Córdoba province), southwestern Spain.

OCCURRENCE IN THE MARITIME PROVINCES: Cumberland Basin (Nova Scotia): Bell (1944): locality 162 (nine pieces without catalogue number); locality 999 (GSC 9578 + GSC 9579 - both poorly preserved); locality 1080 (two pieces without catalogue number); locality 1406 (GSC 9318 - with doubt + GSC $9321+$ GSC 9324 + four pieces without catalogue number together with Karinopteris acuta and Asterophyllites sp. indet.); locality 1412 (GSC 9325 - holotype of Annularia aculeata); locality 1420 (GSC 9322 - here refigured, as part, in Fig. 9b); locality $1435=1406$ (four pieces without catalogue number - together with Alethopteris decurrens and Bergeria dilatata); locality 1728 (cf. - four pieces without catalogue numbers). Minto COALfield (New Brunswick): Bell (1962): locality 1000 (GSC 837).

OCCURRENCE IN THE UNITED STATES: AlabAMA: Gillespie and Rheams (1985); Lyons et al. (1985). Georgia: Gillespie and Crawford (1985). Missouri: Basson (1968). West Virginia: Jongmans (1937); Gillespie et al. (1966); Gillespie et al. (1978).

\section{Annularia stopesiae sp. nov.}

(Figs. 11-12)

p 1938 Annularia stellata forma mucronata, Bell, pl. XC, fig. 1; non p. 85, pl. LXXXIX (= Annularia inflata); non pl. XC, fig. 2 (= Annularia sp.); pl. XCI, fig. 1 (= Annularia inflata).

*v 1944 Annularia stellata forma longifolia, Bell, p. 102, pl. LXX, fig. 5 (holotype of the new species; see Fig. 11).

? 1949 Annularia stellata, Arnold, p. 184, pl. XVII, fig. 1 (incomplete leaves).

v 1966 Annularia stellata forma longifolia, Bell, p. 22, pl. X, fig. 4 (here Fig. 12).

? 1978 Annularia pseudostellata, Gillespie et al., p. 74, pl. 26, fig. 2 (fragmentary; showing epidermal cell pattern).

v 1995 Annularia cf. stellata, Álvarez-Vázquez, pp. 270 -271, lám. 90, figs. 1-2.

p 1980 Annularia stellata, Zodrow and McCandlish, pl. 95, fig. 1; non pl. 94, fig. 1 (?), fig. 2 (= Annularia cf. fertilis); non pl. 95, fig. 2 (= Annularia inflata).

vp 2010 Annularia stellata, Wagner and Álvarez-Vázquez, p. 266; non pp. $270,273,274,276,282,284,291$, 301 (= Annularia stellata).

HOLOTYPE: GSC 9876, a specimen described and figured by Bell 1944 (pl. LXX, fig. 5) as Annularia stellata forma longifolia (Fig. 11 of the present paper).

DERIVATION OF NAME: Named after Marie C. Stopes in recognition of her significant contribution to Canadian palaeobotany through her work at Fern Ledges, Saint John.

TYPE LOCALITY AND HORIZON: Mapleton Brook, Springhill area, 300 feet below driving dam (GSC locality 3116).

DIAGNOSIS: Anisophyllous verticils flattened in spread out condition; 20-24 linear-lanceolate leaves, up to $85 \mathrm{~mm}$ long and 1.5-2 $\mathrm{mm}$ broad. Vein straight, broad and well marked.

DESCRIPTION: Ultimate axes $2-5 \mathrm{~mm}$ wide, with internodes $16-45 \mathrm{~mm}$ apart bearing slightly overlapping verticils which are flattened in spread-out condition; anisophyllous (slightly elliptical), with the lateral leaves longer than those situated in lower and upper parts. Each verticil consists of 20-24 large, linear-lanceolate leaves, united at the base so as to form an annulus. Dimensions: 40 (incomplete) - $85 \mathrm{~mm}$ length at $1.5-2 \mathrm{~mm}$ width; length/breadth ratio $=50-56$. Vein straight, broad and well marked in the central part of a thick leaf lamina. 


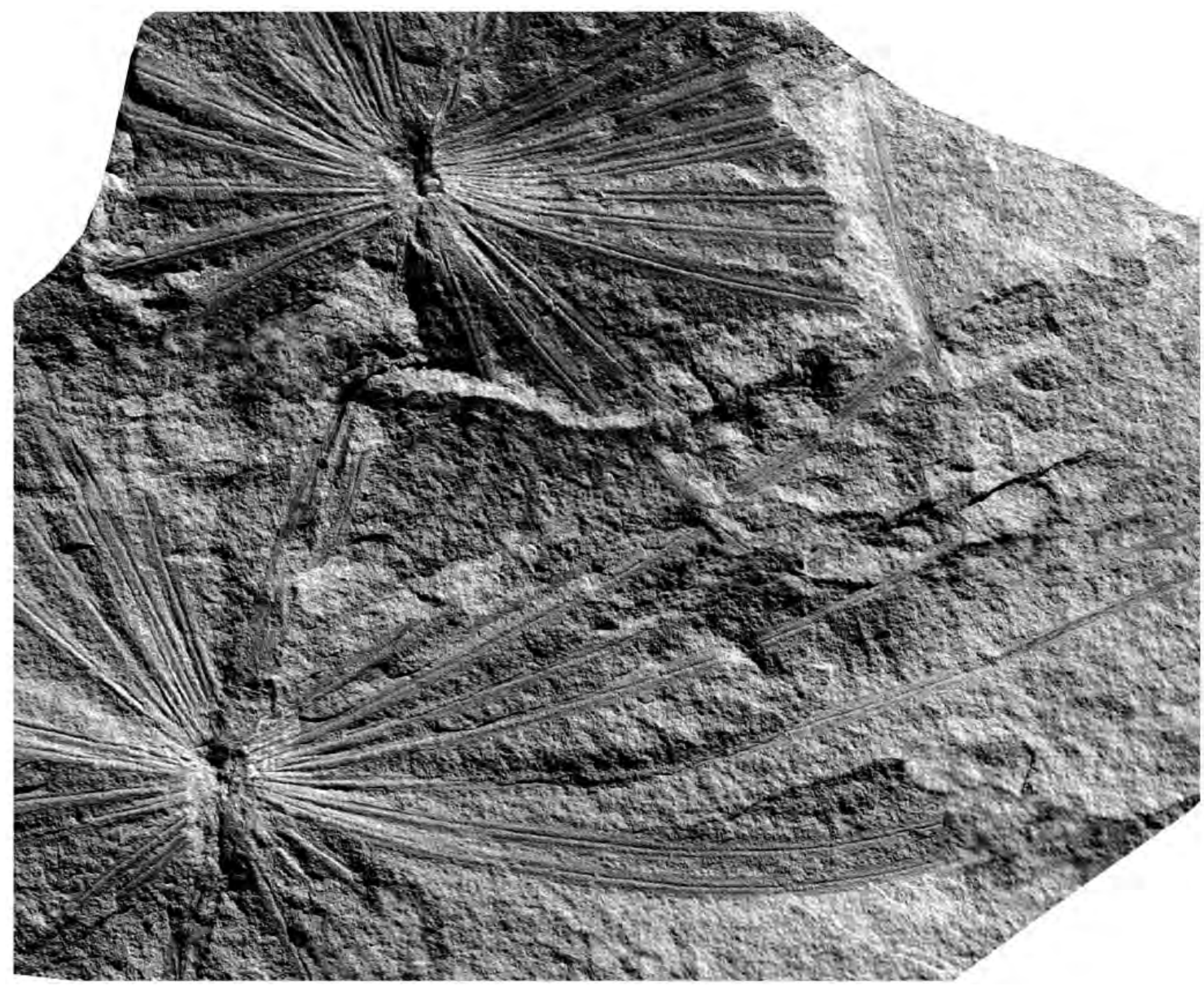

Figure 11. Annularia stopesiae (x 2). Holotype. GSC 9876. Note the long, linear-lanceolate leaves in anisophyllous whorls. Specimen figured by Bell (1944, pl. LXX, fig. 5) as Annularia stellata forma longifolia. Origin: Mapleton Brook, Springhill area, Nova Scotia, 300 feet below driving dam (locality 3116). Repository: Geological Survey of Canada, Ottawa.

REMARKS: Bell (1944, pl. LXX, fig. 5; 1966, pl. X, fig. 4) figured two specimens of Annularia with very long, thin leaves, more than 20 per verticil, from two different localities at Springhill, Cumberland Basin, Nova Scotia. Bell (1944, p. 102) also recorded another (unfigured) specimen, from the Joggins section. All these specimens are preserved in a similar lithology. Bell applied the name Annularia stellata forma longifolia. However, this is based on the invalid species name Annularia longifolia (see Remarks on Annularia inflata). Leaf size in Bell's specimens is comparable to that known for Annularia inflata, but its leaves are narrower and linear-lanceolate. Bell (1944) observed a transverse epidermal cell pattern that he described as "... short hair-like fibres that run generally transverse to the midrib..."; this is characteristic for Annularia spinulosa (= Annularia stellata).

Specimens similar to those recorded by Bell from Canada, also showing the transverse epidermal cell pattern, have been recovered from five different localities in lower Bolsovian strata at the eastern end of the Peñarroya-Belmez-Espiel coalfield, southwestern Spain (Álvarez-Vázquez 1995, pp. 270-271, lám. 90, figs. 1-2, labelled Annularia cf. stellata).

COMPARISONS: Annularia inflata has shorter and broader oblanceolate leaves with an obtuse apex. Length/ breadth ratio is much lower, between 8-10. Annularia spinulosa also possesses slightly anisophyllous verticils 


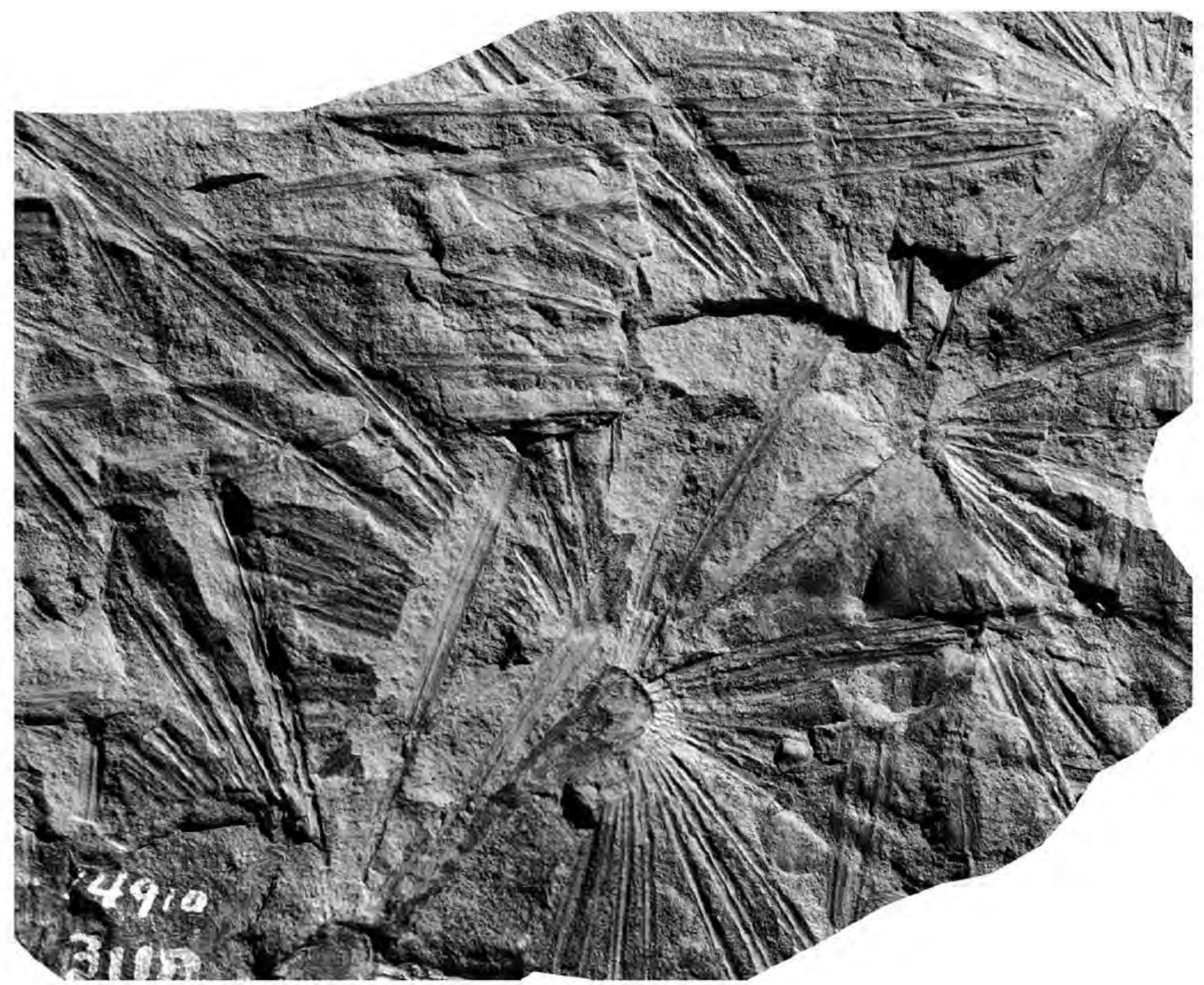

Figure 12. Annularia stopesiae (x 2). GSC 14910. Note the broad vein, strongly marked in a thick lamina. Figured as Annularia stellata forma longifolia by Bell (1966, pl. X, fig. 4). Origin: Captain Henry Mill's Brook, tributary to Maccan River, Springhill area, Nova Scotia (locality 3110). Repository: Geological Survey of Canada, Ottawa.

with a similar number of leaves, but these are shorter (around $30 \mathrm{~mm}$ ), lanceolate, with bluntly pointed apices; length/breadth ratio is lower. Asterophyllites longifolius has a similar number of long, narrow leaves, but these are shorter and joined in isophyllous verticils. In addition, Asterophyllites longifolius leaves are normally flattened sideways, close to the axis, at an angle of less than $45^{\circ}$.

STRATIGRAPHIC AND GEOGRAPHIC DISTRIBUTION: Spanish material included in the synonymy comes from lower Bolsovian strata of the Peñarroya-BelmezEspiel coalfield, Córdoba province, southwestern Spain.
OCCURRENCE IN THE MARITIME PROVINCES: Cumberland Basin (Nova Scotia): Bell (1944): locality 3116 (GSC 9876 - holotype; refigured in Fig. 11). Bell (1966): locality 3110 (GSC 14910 - Fig. 12 + one piece without catalogue number). Minto COALField (New Brunswick): Bell (1966): locality 1172 (GSC 14908 - with doubt).

OCCURRENCE IN THE UNITED STATES: Michigan: Arnold (1949). West Virginia: Gillespie et al. (1978). 


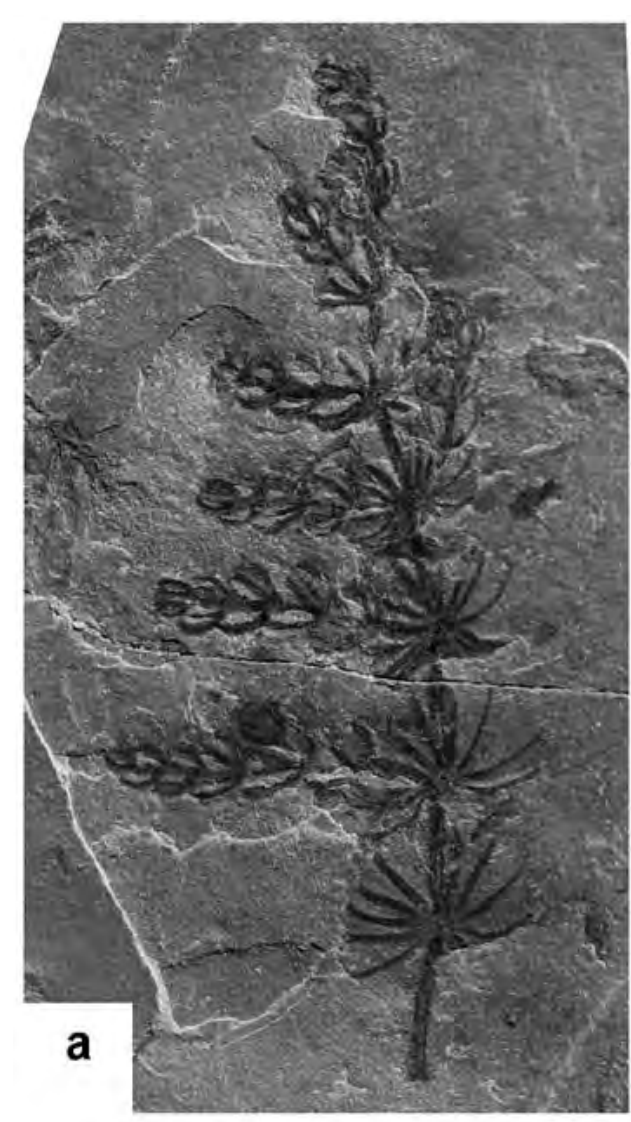

Figure 13. Asterophyllites charaeformis (x 3). NMMG 3435. Counterpart of the specimen figured by Matthew (1906a, pl. VI, fig. 3) as Asterophyllites parvulus var. Origin: Bed 2, Fern Ledges, Lancaster, New Brunswick. Repository: New Brunswick Museum, Saint John.

\section{Genus Asterophyllites Brongniart 1822}

p 1820 Casuarinites Schlotheim, p. 397 (illegitimate name; included by Brongniart 1822 in Asterophyllites).

1821 Schlotheimia Sternberg, p. 28 (illegitimate name; used previously for certain bryophytes).

1822 Asterophyllites Brongniart, p. 210 (nomen conservandum).

p 1825 Bornia Sternberg, p. 28 (nomen rejiciendum).

1825 Bruckmannia Sternberg, p. 29 (nomen rejiciendum).

1836 Hippurites Lindley and Hutton, p.105.

1869 Calamocladus Schimper, p. 323 (acc. to Zeiller 1888).

1880 Asterophyllum Schimper, p. 175 (acc. to Zeiller 1888).

TYPE: Asterophyllites radiatus Brongniart (= Annularia radiata Brongniart).

\section{Asterophyllites charaeformis (Sternberg 1825)} Göppert 1844

(Fig. 13)

* 1825 Bechera charaeformis Sternberg, p. 30, Taf. LV, figs. 3, 5.

$\$ 1844$ Asterophyllites charaeformis, Göppert, p. 198.

* 1860 Asterophyllites gracilis Lesquereux, p. 310, pl. II, figs. 4-4a (acc. to Kidston 1911).

* 1861 Asterophyllites parvula Dawson, p. 168, Fig. 6 (acc. to Bell 1944).

1862 Asterophyllites parvula Dawson, p. 311.

1868 Asterophyllites parvula Dawson, p. 539, Fig. 188Aa-c (same as Dawson 1861).

* 1875 Asterophyllites? minutus Andrews, pp. 424-425, pl. 51, figs. 4-4a (Andrews noted the resemblance with Asterophyllites parvula and Asterophyllites gracilis, both synonyms of Asterophyllites charaeformis).

p 1879-80 Asterophyllites gracilis Lesquereux, pp. 4243, pl. II, figs. 4-4c; non pl. II, figs. 5-5a (= Calamostachys charaeformis).

p 1884a Asterophyllites gracilis Lesquereux, pp. 714715, pl. XCIII, fig. 3; non pl. XCIII, fig. 4 (= Calamostachys charaeformis); non pl. XCIII, figs. 5-6 (strobilus); non pl. XCIII, fig. 7 (Calamites stem).

p 1884b Asterophyllites gracilis Lesquereux, pp. 43-44, pl. 6, figs. 4-4a (same as Lesquereux 1884a, pl. XCIII, fig. 3); non pl. 6, figs. 5-5a (= Calamostachys charaeformis - same as Lesquereux 1884a, pl. XCIII, fig. 4); non pl. 6, fig. 6 (= strobilus - same as Lesquereux 1884a, pl. XCIII, fig. 5).

* 1887 Asterophyllites Roehli Stur, pp. 209-211, Taf. XIV, figs. 10-13a, 13b-c(=Calamostachys); Taf. XVb, fig. 3 (acc. to Kidston 1911).

1900 Asterophyllites arkansanus White, p. 897 (new name for Lesquereux's Asterophyllites gracilis).

v 1906a Asterophyllites parvulus, Matthew, pp. 122123, pl. VI, figs. 1-2, fig. 3 (here Fig. 13).

1911 Asterophyllites charaeformis, Jongmans, pp. 232-234, figs. 190-191.

1914 Asterophyllites parvulus (=A.grandis?), Stopes, p. 20 (Stopes noted the similarity of Dawson's species with Asterophyllites grandis, as pointed out already by White 1900).

1937 Asterophyllites grandis, Jongmans, p.409, pl.32, fig. 102.

1940 Asterophyllites charaeformis, Bell, p. 129, pl.X, fig. 3.

v 1944 Asterophyllites charaeformis, Bell, p. 103, pl. LXIII, fig. 2; pl. LXVIII, fig. 1 (together with Annularia aculeata). 
vp 1944 Annularia aculeata Bell, pl. LXII, fig. 2; pl. LXIII, fig. 4; non pl. LXV, fig. 4 (? - poorly preserved); pl. LXVIII, fig. 1; non pp. 101-102, pl. LX, figs. 3-4 (= Annularia ramosa); non pl. LXV, fig. 1 (?); non pl. LXVIII, fig. 4 (= Annularia ramosa); non pl. LXIX, figs. 1-2 (= Annularia ramosa); non pl. LXVI, fig. 1 (= Annularia sp. indet.); non pl. LXVI, fig. 3 (= Asterophyllites grandis); non pl. LXIX, fig. 3 (= Asterophyllites sp. indet.); non pl. LXIX, fig. 6 (fragmentary - Asterophyllites sp. indet.).

1958 Asterophyllites charaeformis, Abbott, pp. 296, 298, pl. 35, fig. 2 (drawing); pl. 48, fig. 85 (holotype of Asterophyllites gracilis), fig. 86; chart 1.

1959 Asterophyllites charaeformis, Gothan etal., p. 55, Taf. 17, figs. 2-5.

1961 Asterophyllites charaeformis, Leggewie and Schonefeld, pp. 32-33; Taf. 26, figs. 1-2.

1966 Asterophyllites, Gillespie et al., pl. 12, fig. 7.

1977 Asterophyllites charaeformis, Pfefferkorn and Gillespie, pl. 2, fig. D.

1978 Asterophyllites charaeformis, Gillespie et al., p. 70, pl. 25, figs. 1,4 .

1979 Asterophyllites charaeformis, Gillespie and Pfefferkorn, pp. 90, 92, pl. 2, fig. 6.

1981 Asterophyllites charaeformis, Leary, pp. 59, 78, pl. 6, fig. 7.

1981 Asterophyllites charaeformis, Pfefferkorn and Gillespie, pl. 2, fig. 10.

1985 Asterophyllites charaeformis, Gillespie and Rheams, pp. 194, 199, pl. II, fig. 5.

1985 Asterophyllites charaeformis, Lyons et al., pp. 216, 220, 237, pl. V, figs. f-g; pl. XI, fig. c.

1985 Asterophyllites grandis, Gillespie and Crawford, pp. 252, 255, pl. III, fig. 3.

1986 Asterophyllites charaeformis, Gillespie and Pfefferkorn, p. 128, pl. 3, figs. 5-6.

1989 Asterophyllites charaeformis, Gillespie et al., p. 5 , pl. 1 , fig. 8 .

1996 Asterophyllites charaeformis, Cross et al., p. 444, fig. 23-13.2 (or Calamostachys?), fig. 23-13.3.

1997 Asterophyllites charaeformis, Blake, p. 83, pl. 4, fig. 3.

T 1997 Asterophyllites charaeformis, Kvaček and Straková, p. 48, pl. 13, fig. 1 (same as Sternberg 1825, Taf. LV, fig. 5).

2002 Asterophyllites charaeformis, Blake et al., pp. 268, 291, pl. XVI, fig. 5.

2005 Asterophyllites charaeformis, Bashforth, pp. 45-46, pl. 4, figs. 10-11.

2005 Asterophyllites charaeformis, Dilcher et al., p. 159, Figs. 3.8, 3.10.

2005 Asterophyllites charaeformis, Dilcher and Lott, pl. 126, figs. 1-2 (same as Dilcher et al. 2005, Figs. 3.8, 3.10), figs. 3-4. v 2010 Asterophyllites charaeformis, Wagner and Álvarez-Vázquez, pp. 257, 266.

Excludenda:

1941 Asterophyllites charaeformis, Arnold, pl. I, fig. 2 (difficult to judge from the illustration, but possibly a conifer branchlet).

1967 Asterophyllites charaeformis, Tidwell, p. 27, pl. 9, fig. 1 (resembles Asterophyllites grandis).

DESCRIPTION: Penultimate axes striate longitudinally (not always discernible), c. $1 \mathrm{~mm}$ wide; internodes 7-12 $\mathrm{mm}$ long, showing two oppositely inserted, small (10-20 $\mathrm{mm}$ long), smooth ultimate branches, with internodes $2-3$ $\mathrm{mm}$ long.Verticils composed of up to 10 acicular leaves, as long as or slightly longer than the internodes, attached at right angles and reflexed sharply upwards to a position parallel to the next internode, with the acute apex often incurved towards the axis. Dimensions: $2-3 \mathrm{~mm}$ long and $0.2-0.3 \mathrm{~mm}$ wide at the base; length $/$ breadth ratio $=10$.

REMARKS: Bell (1944, pl. LXIII, fig. 2; pl. LXVIII, fig. 1) figured two distinctive specimens of Asterophyllites charaeformis. We also include in this species two specimens described by Bell (1944) as Annularia aculeata (Bell 1944, pl. LXII, fig. 2; pl. LXIII, fig. 4). An incomplete strobilus was figured as Calamostachys charaeformis by Bell (1944, pl. LXX, fig. 1).

The vegetative leaves of Calamostachys charaeformis are distinctive. Two specimens that Bell (1944, pl. LXVII, fig. 5; pl. LXXIV, fig. 5) identified as "Calamostachys of Asterophyllites grandis", are included here in Calamostachys charaeformis; also the specimens figured by Bell (1944, pl. LXXIV, figs. 4, 7) as "Calamostachys of Annularia aculeata". We also include in Calamostachys charaeformis the specimen figured by Stopes (1914, pl. III, fig. 4) as Calamostachys sp.

COMPARISONS: The hooked shape of leaves of Asterophyllites charaeformis is distinctive. The slightly larger, sickle-shaped leaves of Asterophyllites grandis distinguish that species from Asterophyllites charaeformis. The same difference in bract shape separates Calamostachys charaeformis and Calamostachys grandis. Asterophyllites lycopodioides has 4-6 acicular leaves of similar size, but these are closely adpressed to the axis and only slightly curved. In addition, each verticil reaches the next one.

STRATIGRAPHIC AND GEOGRAPHIC DISTRIBUTION: Asterophyllites charaeformis is a fairly common species. In Europe, it occurs usually in lower Langsettian to upper Bolsovian strata, but Kotasowa (1968) also recorded (but did not illustrate) it from the upper Namurian (Yeadonian) of the Upper Silesian Basin. The type material is from the Bolsovian strata of the Radnice Member, Kladno Formation, Bohemia, Czech Republic. 
OCCURRENCE IN THE MARITIME PROVINCES: Cumberland Basin (Nova Scotia): Bell (1944): locality 162 (three pieces without catalogue number); locality 881 (GSC 5984 - Calamostachys charaeformis); locality 1070 (GSC 10187 + GSC 10185); locality 1086 (GSC 9994 - together with Sphenophyllum cuneifolium and Karinopteris acuta); locality 1125 (one piece without catalogue number); locality 1190 (GSC 9019); locality 1374 (GSC 10990 — with cf.); locality 1686 (GSC 8238); locality 2253 = locality 1386 (one piece without catalogue number - together with Laveineopteris polymorpha); locality 3995 (two pieces without catalogue number). AlberT County (New Brunswick): Bell (1944): locality 621 (GSC 8565 - Calamostachys charaeformis + GSC 9135); locality 647 (GSC 10869 - Calamostachys charaeformis). FERN LEdges (New Brunswick): New Brunswick Museum collection: NBMG 3435 (here Fig. 13) + NBMG 3436 (together with Annularia asteris and Alethopteris sp. indet.). Pictou coalfield (Stellarton Basin), Nova Scotia: Bell (1940): locality 1153 (GSC 10409).

OCCURRENCE IN THE UNITED STATES: Alabama: Lesquereux (1879-1880), Lesquereux (1884a, 1884b), Gillespie and Rheams (1985), Lyons et al. (1985), Dilcher and Lott (2005), Dilcher et al. (2005). ArkANsAs: Lesquereux (1860), Lesquereux (1879-1880), Lesquereux (1884b), Abbott (1958). Georgia: Lesquereux (1884a, 1884b). Оніо: Andrews (1875), Abbott (1958). West Virginia: Jongmans (1937); Gillespie et al. (1966), Pfefferkorn and Gillespie (1977); Pfefferkorn and Gillespie (1981); Gillespie et al. (1978).

Asterophyllites grandis (Sternberg 1825) Geinitz 1855 (Fig. 14)

* 1825 Bechera grandis Sternberg, p. 42, Taf. XLIX, fig. 1.

* 1825 Bechera delicatula Sternberg, p. 42, Taf. XLIX, fig. 2 (acc. to Kidston 1886).

* 1828a Asterophyllites pygmaeus Brongniart, p. 150 (nomen nudum) (acc. to Schimper 1869 who re-examined Brongniart's specimen).

§ 1855 Asterophyllites grandis, Geinitz, p. 8, Taf. XVII, fig. 4.

p 1871 Asterophyllites acicularis Dawson, pp. 28-29, pl. $\mathrm{V}$, figs. 54; non pl. V, figs. 54a-54c (indeterminate Annularia leaves); non pl. V, figs. 55-56 (strobili); non pl. V, fig. 57 (stem).

1884b Asterophyllites fasciculatus, Lesquereux, p. 43, pl. 6, fig. 7.

1886-88 Asterophyllites grandis, Zeiller, p. 376, pl. LIX, figs. 4, 7; non pl. LIX, figs. 5-6A (=Calamostachys).

vp1944 Asterophyllites grandis, Bell, p. 104, pl. LXIX, fig. 4; pl. LXXII, figs. 1, 4; pl. LXXV, fig. 1; non pl. LXVII, fig. 5 (= Calamostachys charaeformis); non pl. LXX, figs. 3-4 (= Calamostachys grandis); non pl. LXXII, figs. 2-3 (= Calamostachys grandis); non pl. LXXIV, fig. 5 (= Calamostachys charaeformis).

vp 1944 Annularia aculeata Bell, pl. LXVI, fig. 3 (here Fig. 14); non pp. 101-102, non pl. LX, figs. 3, 4 (= Annularia ramosa); non pl. LXII, fig. 2 (= Asterophyllites charaeformis); non pl. LXIII, fig. 4 (= Asterophyllites charaeformis); non pl. LXV, fig. 1 (= Asterophyllites cf. charaeformis); non pl. LXV, fig. 4 (poorly preserved - maybe Asterophyllites charaeformis); non pl. LXVIII, fig. 1 (= Asterophyllites charaeformis); non pl. LXVIII, fig. 4 (= Annularia ramosa); non pl. LXIX, figs. 1-2 (= Annularia ramosa); non pl.LXVI, fig. 1 (=Annullaria sp. indet.); non pl. LXIX, fig. 3 (= AsteroAsterophyllites sp.); non pl. LXIX, fig. 6 (= Asterophyllites sp. indet.).

1958 Asterophyllites grandis, Abbott, pp. 302-303; chart 1.

1962 Asterophyllites grandis, Bell, p. 49, pl. XLV, fig. 3; pl. XLVII, fig. 4.

1966 Asterophyllites, Gillespie et al., pl. 12, fig. 5.

?p 1967 Asterophyllites equisetiformis, Tidwell, p. 27, pl. 4 , fig. 1 (difficult to judge from the illustration); pl. 5, fig. 1 (difficult to judge from the illustration

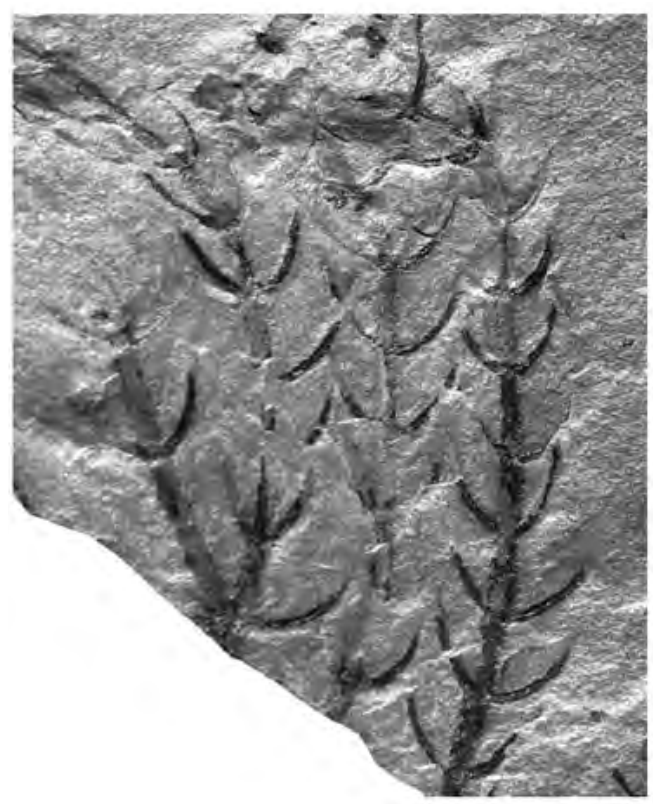

Figure 14. Asterophyllites grandis (x 3). GSC 9931. Specimen figured as Annularia aculeata by Bell (1944, pl. LXVI, fig. 3). Origin: South Brook, Leamington, Cumberland County, Nova Scotia (locality 1162). Repository: Geological Survey of Canada, Ottawa. 
- together with Sphenopteris sp. indet.); non pl. 9, fig. 2 (difficult to judge, but probably Annularia sp.).

? 1967 Asterophyllites charaeformis, Tidwell, p. 27, pl. 9, fig. 1 (fragmentary verticil associated with Calamostachys sp. indet.).

1978 Asterophyllites grandis, Gillespie et al., p. 70, pl. 25, fig. 2 (same as Gillespie et al. 1966, pl. 12, fig. 5), pl. 25, fig. 4.

T 1997 Asterophyllites grandis, Kvaček and Straková, pp. 62, 82, pl. 18, fig. 4 (holotype of Bechera delicatula); pl. 25, fig. 4 (holotype of Bechera grandis).

2014 Asterophyllites grandis, Bashforth et al., pp. 243, 245, pl. 1, fig. 2.

Excludenda:

1937 Asterophyllites grandis, Jongmans, p. 409, pl. 32, fig. 102 (= Asterophyllites charaeformis).

DESCRIPTION: Ultimate axis $0.30-0.50 \mathrm{~mm}$ wide, longitudinally striate, with internodes $2.5-4 \mathrm{~mm}$ long that become shorter and thinner towards the apex. Leaves slightly shorter than the internodes, thread-like, inserted at acute angles and curving slightly towards the axis in the upper half. Dimensions: $4-6 \mathrm{~mm}$ long and 0.3-0.4 $\mathrm{mm}$ broad; length/breadth ratio $=13-15$. Vein not visible.

REMARKS: Bell (1944) figured two specimens of Asterophyllites grandis that are easily recognized by their sickle-shaped leaves, which overlap slightly at successive whorls. Bell also attributed four specimens of Calamostachys to Asterophyllites grandis, two of which are reassigned here to Calamostachys charaeformis. The cylindrical strobili of Asterophyllites grandis possess bracts similar to the vegetative leaves, and sporangiophores situated at about middle distance between verticils.

The similar species Asterophyllites tayloriorum, described from South Wales, is indistinguishable from Asterophyllites grandis in the vegetative state, but differs with regard to its associated fertile remains, assigned to Palaeostachya wagneri (Cleal and Shute 2016).

COMPARISONS: Asterophyllites charaeformis has smaller, distinctively reflexed leaves placed at right angles. Leaves of Asterophyllites lycopodioides are less curved and pass beyond the internode to touch the base of the next verticil.

STRATIGRAPHIC AND GEOGRAPHIC DISTRIBUTION: Asterophyllites grandis occurs in Yeadonian to upper Bolsovian strata. Type material of Bechera grandis and Bechera delicatula are both from Bolsovian strata of the Radnice Member, Kladno Formation, Bohemia, Czech Republic.
OCCURRENCE IN THE MARITIME PROVINCES: Cumberland BAsin (Nova Scotia): Bell (1944): locality 1039 (GSC 9054 + GSC 9067a - together with Sphenopteris sp., Calamites suckowii and Cyperites); locality 1052 (two pieces, part and counterpart, with catalogue numbers unclear as a result of damage to the specimen - together with Renaultia sp. and Cordaites sp.); locality 1162 (GSC 9931 - together with Calamites sp.; here Fig. 14); locality 1362 (GSC 10989); locality 1406 (GSC 9134); locality 1675 (one piece without catalogue number - Calamostachys grandis). Albert County (New Brunswick): Bell (1944): locality 621 (GSC 9135 + GSC 9376 - Calamostachys grandis); locality 1401 (GSC 6554-Calamostachys grandis). Minto COALField (New Brunswick): Bell (1962): locality 5430 (GSC 937 + GSC 938).

OCCURRENCE IN THE UNITED STATES: OHIO: Abbott (1958). Utah: Tidwell (1967). West Virginia: Gillespie et al. (1966), Gillespie et al. (1978).

\section{Asterophyllites lindleyanus Göppert 1848}

(Fig. 15; Figs. 16a-c)

*p 1835 Hippurites longifolia Lindley and Hutton, p. 106, pl. 191 (copied here as Fig. 15); non pl. 190 (= Calamites stems).

$\$ 1848$ Asterophyllites lindleyanus Göppert, p. 122 (substitute name for Lindley and Hutton's Hippurites longifolia).

* ? 1848 Asterophyllites arcuata Sauveur, pl. LXVIII, fig. 2 (fragmentary).

* 1848 Asterophyllites subulata Sauveur, pl. LXIX, fig. 5 (synonym of Asterophyllites equisetiformis acc. to Jongmans 1914b).

* 1868 Asterophyllites trinervis Dawson, p. 479, Fig. 165A (synonym of Calamocladus equisetiformis acc. to Kidston 1886).

* 1875 Asterophyllites erectifolius Andrews, p. 425, pl. XLIX, fig. 3.

* 1876 Calamocladus binervis Boulay, p. 22, pl. II, fig. 1 (probable synonym of Calamocladus equisetiformis acc. to Kidston 1886).

p 1884b Asterophyllites equisetiformis, Lesquereux, p.42, pl. 6, fig. 1; non pl. 6, fig. 2 (strobilus).

p 1886-88 Asterophyllites equisetiformis, Zeiller, pp. 368374, pl. LVIII, figs. 3-7; non pl. LVIII, figs. 1-1B (strobilus), fig. 2 (nodal leaves).

1901 Calamocladus equisetiformis, Kidston, p. 202, pl. XXX, fig. 3.

p 1906a Annularia acicularis, Matthew, pl. V, figs. 2-3; non p. 127, pl. V, fig. 1 (= Annularia pseudostellata).

1913 Asterophyllites equisetiformis forma Schlotheimii, Jongmans and Kukuk, Taf. 17, figs. 2-5.

p 1934 Asterophyllites equisetiformis, Arnold, p. 186, pl. 


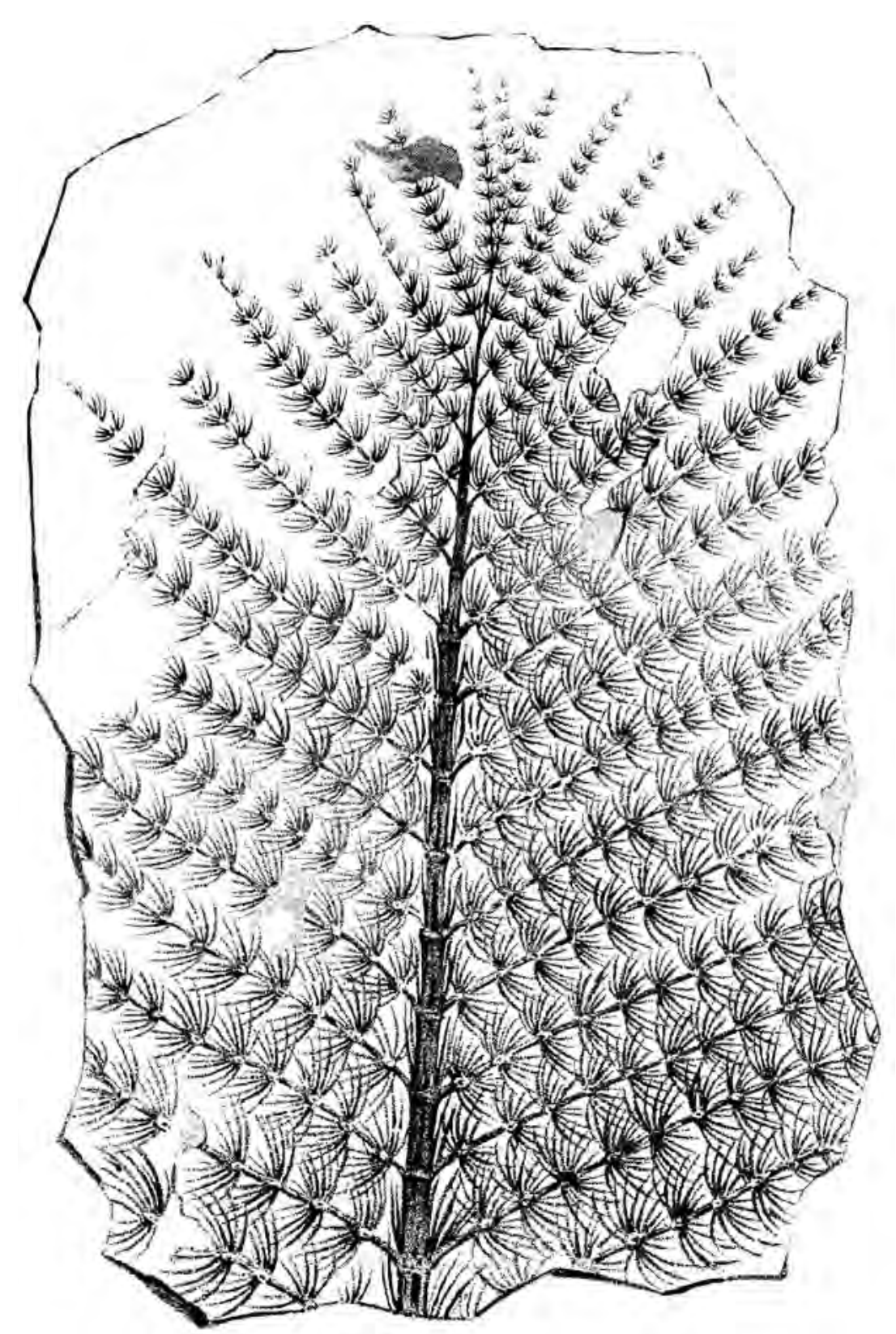

Figure 15. Asterophyllites lindleyanus (x 1). Copy of Hippurites longifolia as figured by Lindley and Hutton (1835, pl. 191); here designated as the lectotype of Asterophyllites lindleyanus.

I, fig. 3; non pl. III, fig. 3 (? - calamitean axis with stem leaves).

1937 Asterophyllites equisetiformis, Jongmans, p. 409, pl. 32, fig. 103.

1938 Asterophyllites equisetiformis, Bell, p. 86, pl. LXXXVII, figs. 3-4; pl. LXXXVIII, fig. 1.

1938 Asterophyllites equisetiformis, Renier and Stockmans in Renier et al., p. 71, pl. 45.

vp 1944 Asterophyllites equisetiformis, Bell, p. 103, pl. LXX, fig. 2 (cf. - fragmentary); pl. LXXI, fig. 3 (here Fig. 16c); non pl. LXXI, fig. 1 (=
Acrobulbillites - here as Fig. 17; name introduced by Amerom 1973 and interpreted as galls at the end of calamitean branchlets).

1949 Asterophyllites equisetiformis, Arnold, p. 183, pl. XVII, figs. 2, 4, 5.

1952-53 Asterophyllites equisetiformis, Stockmans and Willière, p. 185, pl. XLVI, fig. 3.

k 1958 Asterophyllites equisetiformis, Abbott, pp. 299302, pl. 35, fig. 4; pl. 36, figs. 12, 15, 19, 20 (cuticles); pl. 39, figs. 46-47, 49-51; pl. 43, fig. 63; pl. 47, fig. 78 (cuticle); chart 1. 

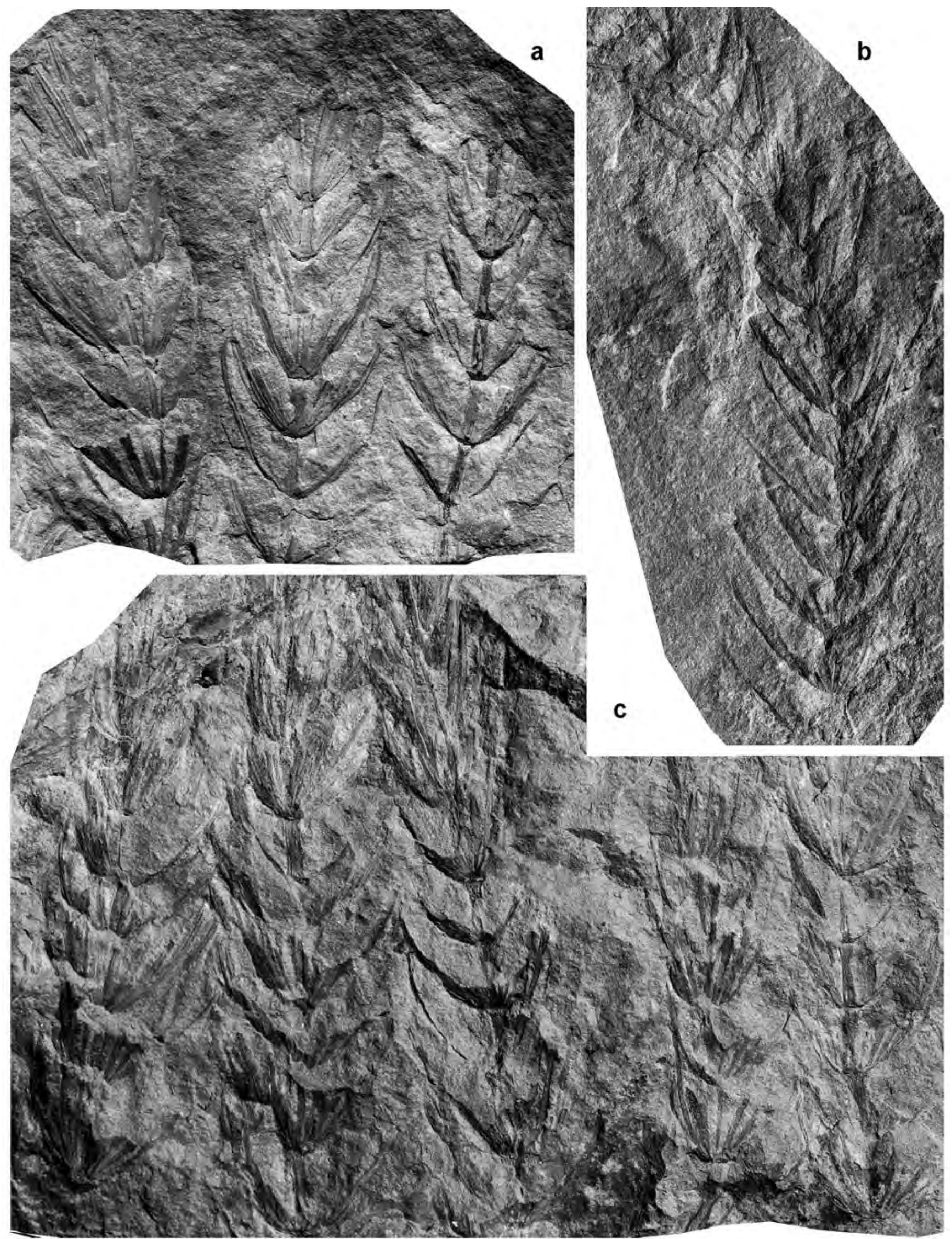
Figure 16. (previous page) (a) Asterophyllites lindleyanus (x3). GSC 10133. Origin: South Brook, tributary of Maccan River, below South Brook settlement, Nova Scotia (locality 1087). (b) Asterophyllites lindleyanus (x 2). Origin: Leamington, South Brook, Nova Scotia (locality 156). (c) Asterophyllites lindleyanus (x 2). GSC 10132. Specimen figured as Asterophyllites equisetiformis by Bell (1944, pl. LXXI, fig. 3). Origin: as for Fig. 16a (locality 1087). Repository: Geological Survey of Canada, Ottawa.

1959 Asterophyllites equisetiformis, Gothan et al., pp. 53-54, Taf. 16, figs. 2-4; Taf. 17, fig. 1.

1961 Asterophyllites equisetiformis f. typica, Leggewie and Schonefeld, pp. 34-35, Taf. 28, figs. 1, 5-6.

1963 Asterophyllites equisetiformis, Wood, pp. 42-43, pl. 4 , fig. 2.

p 1966 Asterophyllitesequisetiformis, Bell,pp. 58,60,pl. XXVIII, fig. 7; pl. XXIX, fig. 4; non p. 74, pl. XXXVI, fig. 3 (difficult to judge from the the illustration).

p 1969 Asterophyllites equisetiformis forma typica, Crookall, pp. 695-700, pl. CXLII, fig. 3 (same as Kidston 1901, pl. XXX, fig. 3); non text-fig. 203 (copy of Geinitz 1855, Taf. XVII, fig. 1, topotopotype of Schlotheim's species).

? 1989 Asterophyllites equisetiformis, Gillespie et al., p. 5 , pl. 1, fig. 6.

v 1995 Asterophyllites cf. equisetiformis, ÁlvarezVázquez, pp. 275-276, lám. 88, figs. 3-4.

2005 Asterophyllites equisetiformis, Bashforth, p. 46, pl. 6, figs. 2, 5.

v 2010 Asterophyllites cf. equisetiformis, Wagner and Álvarez-Vázquez, pp. 257, 266, 268.

Excludenda:

1967 Asterophyllites equisetiformis, Tidwell, p. 27, pl. 4, fig. 1 (cf. Asterophyllites grandis); pl. 5, fig. 1 (= Asterophyllites grandis); pl. 9, fig. 2 (difficult to judge, but possibly a species of Annularia).

LECTOTYPE (DESIGNATED HEREIN): The specimen figured by Lindley and Hutton (1835, pl. 191) as Hippurites longifolia. Lindley and Hutton's drawing is refigured here as Fig. 15.

DESCRIPTION: Ultimate axes with fine longitudinal striae, straight, 1-1.5 mm wide, with internodes 5-10 mm long, becoming shorter and narrower upwards. Verticils with up to 16 closely placed, linear-lanceolate leaves, showing nearly parallel margins and an acute apex; lower leaves attached at approximate right angles and curved at about mid-length; higher leaves are more or less straight and attached at acute angles. Dimensions; $10-14 \mathrm{~mm}$ long and $0.5-0.75 \mathrm{~mm}$ broad; length $/$ breadth ratio $=18-20$.

REMARKS: The (missing) type material of Schlotheim's Asterophyllites equisetiformis (originally Casuarinites equisetiformis) originated from upper Stephanian strata of Wettin and Manebach, eastern Germany. Most authors acknowledge that a varied group of similar taxa has been figured under this name in the literature. Jongmans and Kukuk (1913) recorded as Asterophyllites equisetiformis forma schlotheimii the form introduced by Schlotheim (1820) for uppermost Stephanian (lower Permian?) material characterized by leaves that are relatively broad, are broadest at about one third above the base, and possess a sharply pointed apex. The taxon with more thread-like, narrow and parallel-sided leaves that occurs throughout the Westphalian Stage (up to the lower Asturian) was named Asterophyllites equisetiformis forma jongmansii by Josten (1991), who applied the name Asterophyllites equisetiformis forma equisetiformis to the Stephanian (including the upper Asturian) taxon. Josten's Asterophyllites equisetiformis forma jongmansii includes both Asterophyllites equisetiformis forma typica of Jongmans (1914b) and Asterophyllites gothanii (Leggewie and Schonefeld in Gothan et al. 1959); both were poorly defined and inadequately figured. The fragmentary Canadian specimens do not warrant a detailed discussion. Lindley and Hutton's specimen (lectotype) still needs to be reproduced photographically; however, we suggest for the time being that most of the Westphalian specimens recorded in the literature as Asterophyllites equisetiformis may be attributable to Asterophyllites lindleyanus.

Bell (1944) reported Asterophyllites equisetiformis as uncommon in the Cumberland Basin. Bell's specimens (plus additional ones from the same localities) have been available for reexamination. His pl. LXX, fig. 2, representing only a fragment of leaf verticil, and pl. LXXI, fig. 3 (our Fig. 16c), which is a more complete specimen with several ultimate axes showing thin-leaved verticils, fit Josten's Asterophyllites equisetiformis forma jongmansii, from the Westphalian. Bell's pl. LXXI, fig. 1 (our Fig. 17) represents the swollen tip of a branch that may be interpreted as a response to a fungal infection, and attributed to Acrobulbillites (as described by Amerom 1973).

COMPARISONS: Asterophyllites equisetiformis, as found in the higher Stephanian, shows broader leaves with the maximum width at about one third from the base, and a sharply pointed apex. Leaves of Asterophyllites grandis are smaller, more falcate, and less broad than those of Asterophyllites lindleyanus, with a smaller length/ breadth ratio. Leaves of Asterophyllites lycopodioides are shorter and less arched; they pass beyond the node above to touch the base of the next verticil. 


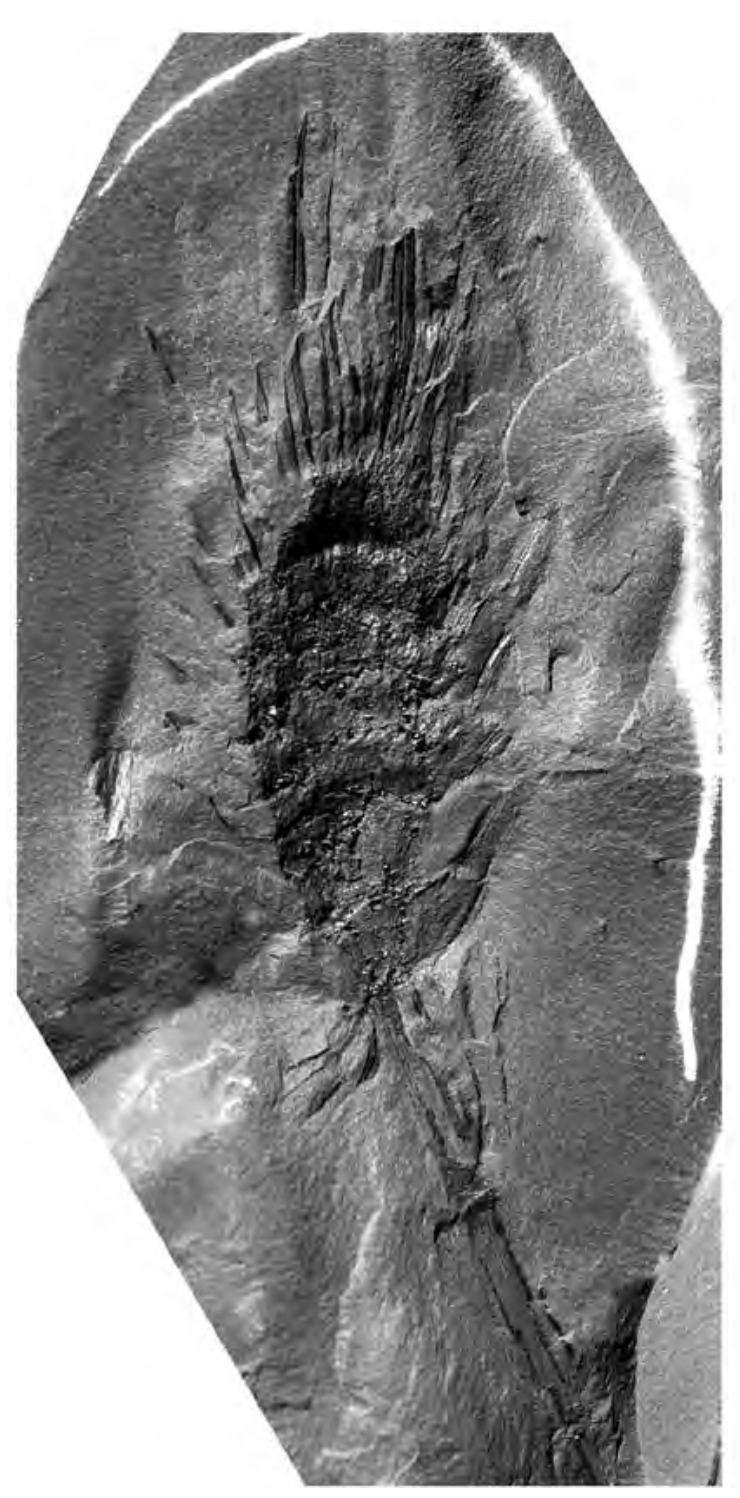

Figure 17. Acrobulbillites sp. (x 2). GSC 9017. Specimen figured by Bell (1944, pl. LXXI, fig. 1) as Asterophyllites equisetiformis. Origin: Springhill, No. 2 mine, from roof shales in waste dump (locality 1039), Nova Scotia. Repository: Geological Survey of Canada, Ottawa.

STRATIGRAPHIC AND GEOGRAPHIC DISTRIBUTION: The species occurs rarely in the Yeadonian, but is relatively common and widespread in Westphalian strata (up to and including the lower Asturian).

OCCURRENCE IN THE MARITIME PROVINCES: Cumberland Basin (Nova Scotia): Bell (1944): locality 136 (poorly preserved - one piece without catalogue number); locality 156 (one piece without catalogue number - here Fig. 16b; together with Zeilleria avoldensis and Sphenophyllum cuneifolium); locality $173 \mathrm{~b}$ (poorly preserved
- one piece without catalogue number); locality 1063 (GSC 9401); locality 1087 (GSC 10132 - Fig. 16c + GSC 10133 - Fig. 16a; together with Dorycordaites palmaeformis + GSC 10134 - with Dorycordaites palmaeformis and Samaropsis sp. + one piece without catalogue number, together with Asterophyllites charaeformis and Samaropsis sp.); locality 2984 (one piece without catalogue number); locality 3001 (GSC 5993 - recorded with cf.; together with Paripteris sp.). Fern Ledges (New Brunswick): New Brunswick Museum collection: NBMG 7030 + NBMG 7043. Sydney Basin (Nova Scotia): locality 518 (GSC 14922).

OCCURRENCE IN THE UNITED STATES: INDIANA: Wood (1963). OHIo: Andrews (1875); Abbott (1958). West VirginiA: Jongmans (1937).

\section{Asterophyllites longifolius (Sternberg 1825) Brongniart 1828}

(Figs. 18, 19)

* 1825 Bruckmannia longifolia Sternberg, p. 45, Taf. LVIII, figs. 1A-B.

* 1825 Bruckmannia rigida Sternberg, p. 29, Taf. XIX, fig. 1 (acc. to Kidston 1886).

$\$ 1828$ a Asterophyllites longifolius, Brongniart, p. 159.

* 1834 Asterophyllites comosus Lindley and Hutton, pp. 73-74, pl. 108 (acc. to Kidston 1886).

*? 1848 Asterophyllites arcuata Sauveur, pl. LXVIII, fig. 2 (fragmentary).

* 1848 Asterophyllites elegans Sauveur, pl. LXVIII, fig. 1 (acc. to Zeiller 1888).

1870 Asterophyllites rigidus, Lesquereux, p. 424, pl. XXI, figs. 4-4a.

${ }^{*} \mathrm{p} 1884$ Asterophyllites striatus Weiss, pp. 192-193 [278-279], Taf. XX, fig. 3; non Taf. XX, figs. 45 (= Palaeostachyastriata) (acc.to Jongmans 1911).

1886-88 Asterophyllites longifolius, Zeiller, p. 374, pl. LIX, fig. 3.

*? 1887 Asterophyllites germarianus Stur, p. 71, Taf.XVb, fig. 1 (acc. to Jongmans 1911).

1899 Asterophyllites longifolius, White, pp. 153-156, pl. XLIX, figs. 2-4.

1906a Asterophyllites longifolius, Matthew, p. 120, pl. I, fig. 3.

*? 1906a Asterophyllites fasciculatus Matthew (non Lesquereux 1879 - who already used the same specific name), p. 121, pl. I, fig. 2 (Fig. $19-$ although based on a fragmentary and poorly preserved holotype, Matthew's species is here tentatively identified with Asterophyllites longifolius).

${ }^{*}$ p 1906a Asterophyllites (?) fissus Matthew, pp. 121-122, pl. VI, figs. 4, 6; non pl. VI, fig. 5 (too fragmentary for a specific determination). 


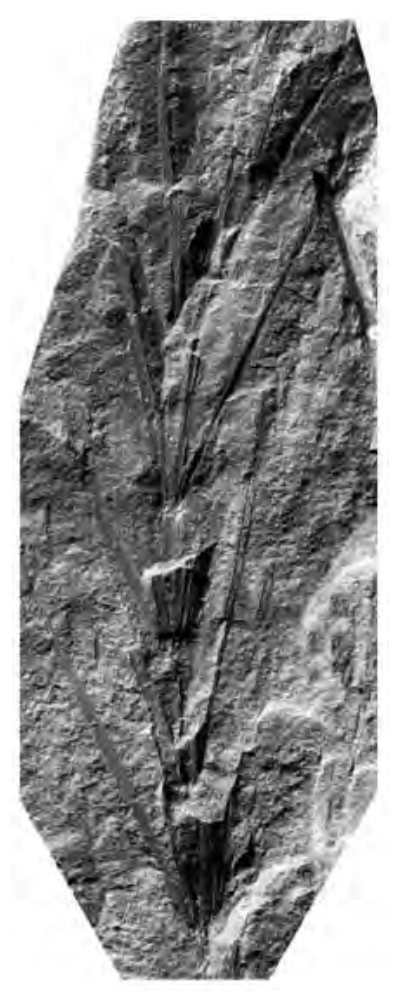

Figure 18. Asterophyllites longifolius (x 3). Origin: Squaw Point, Cape Enragé, Albert County, New Brunswick (locality 626). Repository: Geological Survey of Canada, Ottawa.

${ }^{*}$ p 1906a Ramicalamus dumosus Matthew, pl. VIII, fig. 5; non pp. 115-116, pl. VIII, figs. 2-3 (= Calamites stems); non pl. VIII, fig. 4 (= node).

1940 Asterophyllites longifolius forma striata, Bell, pp. 128-129, pl. III, fig. 5.

1957 Asterophyllites longifolius, Janssen, p. 88, Fig. 72.

1958 Asterophyllites longifolius, Abbott, pp. 303-304, pl. 40, fig. 53; pl. 42, fig. 60; chart 1 .

1958 Asterophyllites longifolius, Langford, p. 43, figs. 51-52.

* 1961 Asterophyllites discifer Leggewie and Schonefeld, pp. 8-11, Taf. 3, figs. 3-6; Taf. 4, figs. 1-3, 5 .

1962 Asterophyllites longifolius, Bell, pp.49-50,pl.XI, figs. 3-4 (together with Palmatopteris furcata); pl. XLV, fig. 1.

1963 Asterophyllites longifolius, Cridland et al., p. 71, pl. 19, fig. 32.

Figure 19. (right) Asterophyllites longifolius? (x3). Holotype of Asterophyllites fasciculatus Matthew (1906a, pl. I, fig. 2). Origin: Bed 7, Fern Ledges, Saint John, Lancaster, New Brunswick. Repository: New Brunswick Museum, Saint John.

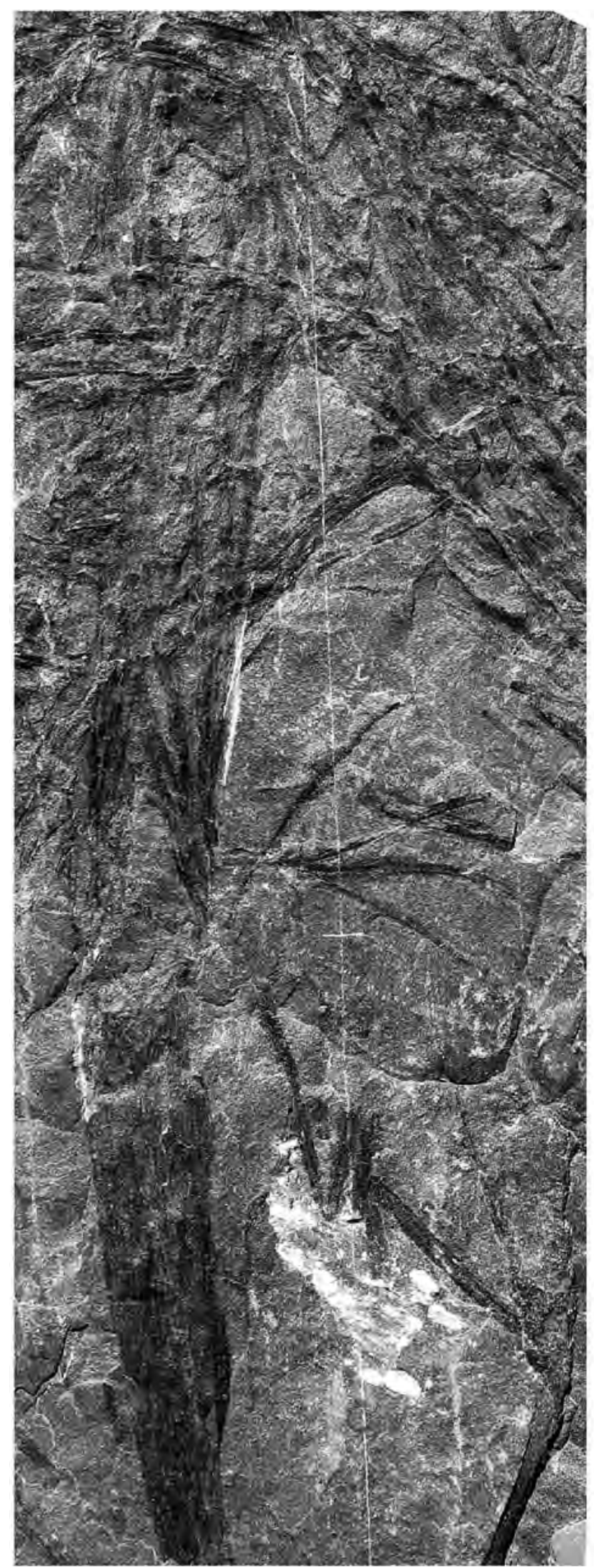


1966 Asterophyllites longifolius, Bell, p. 62, pl. XXX, fig. 2 (fragmentary).

? 1967 Asterophyllites longifolius, Tidwell, pp. 27-28, pl. 4, fig. 6.

? 1967 Archaeocalamites radiatus, Tidwell, pp. 23-24, pl. 8, fig. 9 (small stem with verticils of long, overlapping, narrow leaves).

1969 Asterophyllites longifolius forma typica, Crookall, pp. 704-707 (including synonymy), pl. CL, fig. 2; text-fig. 205 (same as Sternberg 1825, Taf. LVIII, figs. 1A-B).

? 1975 Archaeocalamites foliage, Tidwell, pl. 23, fig. 5 (same as Tidwell 1967, pl. 8, fig. 9).

1987 Asterophyllites longifolius forma striata, Tenchov, p. 46, pl. XVI, figs. 1-2, 12.

1987 Asterophyllites tenuifolius, Tenchov, p. 47, pl.XVI, figs. 3-4, 6.

1991 Asterophyllites longifolius, Josten, pp. 87-89, Taf. 24, figs. 1-1a; Taf. 25.

T 1997 Asterophyllites longifolius, Kvaček and Straková, p. 98, pl. 35, fig. 1 (holotype of Bruckmannia longifolia).

1997 Asterophyllites longifolius, Kvaček and Straková, p. 130, pl. 45, fig. 2 (holotype of Bruckmannia rigida).

2006 Asterophyllites longifolius, Wittry, p. 94, fig. 1.

2011 Asterophyllites longifolius, Pšenička and Opluštil, p. 72, pl. V, figs. 5-6, 8-9; pl. VI, fig. 4; text-fig. 4 (drawing).

Excludenda:

1934 Asterophyllites longifolius?, Read, pp. 81, 83, pl. 16, fig. 8 (incomplete verticils which cannot be assigned specifically, but clearly not belonging to this species).

1938 Asterophyllites longifolius, Bell, p. 86, pl.XCII, fig. 5 (broad leaves which can only be assigned as Annularia sp. indet.).

DESCRIPTION: Ultimate axis $3-4 \mathrm{~mm}$ wide, with ribbed internodes 8-14 mm long. Verticils with up to 20 filiform leaves with acute apices, adpressed in the axial plane, inserted at an acute angle $\left(30-45^{\circ}\right)$, and overlapping 2-4 internodes. Dimensions: 25$40 \mathrm{~mm}$ long and $\sim 1 \mathrm{~mm}$ width. Vein not visible.

REMARKS: Although Bell (1944) did not report Asterophyllites longifolius, he figured a moderately well-preserved specimen of Palaeostachya striata (Bell 1944, pl. LXXIII, fig. 6) from the Springhill area, Nova Scotia. Palaeostachya striata, a species that we consider synonymous with Palaeostachya elongata, is often regarded as the strobilus of Asterophyllites longifolius.

COMPARISONS: Asterophyllites longifolius is easily recognized by its long, filiform leaves that overlap several verticils.

STRATIGRAPHIC AND GEOGRAPHIC DISTRIBUTION: Asterophyllites longifolius is a long-ranging species, from upperNamurian to thelowerStephanian. The holotypeisfrom Westphalian strata at Eschweiler, Aachen coalfield, western Germany. The holotype of its synonym, Asterophyllites rigidus, is from Bolsovian strata of the Radnice beds, Bohemia, Czech Republic. Sauveur's Asterophyllites elegans, another synonym, came from the lower Westphalian of Belgium. Leggewie and Schonefeld's Asterophyllites discifer, also a synonym, came from the Westphalian A (Langsettian) of the Ruhr District, western Germany. Crookall (1969) mentioned that Asterophyllites longifolius is fairly rare, occurring in Langsettian to Bolsovian strata in Great Britain.

OCCURRENCE IN THE MARITIME PROVINCES: New BRUNSWICK: locality 626: unpublished specimen, without catalogue number (here as Fig. 18). Fern Ledges (New BRunswick): Wilson collection from 1884 (one specimen from locality 352 , without catalogue number, here Fig. 19) + New Brunswick Museum collection: NBMG 7721 (labelled as Ramicalamus dumosus); NBMG 3429 (holotype of Asterophyllites fasciculatus - here Fig. 19). Minto COAlfield (New BRUnSwick): Bell (1962): locality 856 (GSC 839); locality 5074 (GSC 943 - together with Palmatopteris furcata). PiCtou COALFIEld (Nova Scotia): Bell (1940): locality 2488 (GSC 10309). Sydney CoAlfield (Nova Scotia): Bell (1938): locality 537 (GSC 2942); locality 1146 (GSC 14909).

OCCURRENCE IN THE UNITED STATES: ILLINOIS: Lesquereux (1870); Janssen (1957); Langford (1958). KANSAs: Cridland et al. (1963). Missouri: White (1899), Abbott (1958). Oнiо: Abbott (1958). UtAн: Tidwell (1967, 1975).

\section{SUMMARY AND CONCLUSIONS}

We have updated the taxonomy of Annularia and Asterophyllites species from lower Westphalian strata of the Maritime Provinces after re-examination of material in the Geological Survey of Canada (GSC) collections in Ottawa, and in the New Brunswick Museum (NBMG) at Saint John.

As with the lycopsid taxa revised in an earlier paper (Álvarez-Vázquez and Wagner 2014), the published record of Canadian sphenopsids from lower Westphalian strata is only sporadic and may be regarded as incomplete. Further collecting might well increase the number of species recognized, but our current revision shows already that 
the species composition of Annularia and Asterophyllites in the Maritime Provinces is identical to that found in western Europe. Both areas obviously represent a single palaeogeographic region.

The profusion of names used by Dawson, Matthew and Bell needed to be scaled down considerably. We have reduced the number of species from 19 to 6 . The following taxa have been maintained: Annularia asteris, Annularia latifolia, Annularia radiata, Asterophyllites charaeformis, Asterophyllites grandis and Asterophyllites longifolius. We have introduced one new species, Annularia stopesiae, based on Canadian specimens but including also material from western Europe that was attributed originally to Annularia stellata. Lesquereux's Annularia inflata is reinstated herein. We make the case for using Göppert's specific name Asterophyllites lindleyanus for Westphalian material commonly referred to as Asterophyllites equisetiformis and, more particularly, as Asterophyllites equisetiformis forma jongmansii.

The parameters used for species discrimination are set out in Tables 1 and 2, for Annularia and Asterophyllites, respectively. Table 3 shows the identifications accepted in the present paper, as compared with those made by Dawson
(1862, 1868, 1871), Matthew (1906a, b) and Bell (1944, 1966).

\section{ACKNOWLEDGEMENTS}

We express our gratitude to John Utting for providing the stimulus for a general revision of lower Westphalian floras in the Maritime Provinces, and accompanying the second author on several visits for which he provided logistic support. Jean Dougherty was most helpful in providing access to material and data regarding the fossil collections of the Geological Survey of Canada in Ottawa. Randall Miller did the same in the New Brunswick Museum at Saint John, providing geological information. Robert Wagner gratefully acknowledges a G.F. Matthew Grant from the New Brunswick Museum. Access to the Dawson Collection at the Redpath Museum, McGill's University, Montreal is also acknowledged. The paper benefited from constructive comments and suggestions by Arden Bashforth and Chris Cleal. Various suggestions by the Editor, Rob Fensome have been well received.

Table 3. List of the various species figured and described in the present paper in comparison with identifications in Bell $(1944,1966)$ Matthew (1906a b) and Dawson $(1862,1868,1871)$

\begin{tabular}{|c|c|c|c|}
\hline Present paper & Bell $(1944 / 1966)$ & Matthew (1906a/1906b) & Dawson $(1862 / 1868 / 1871)$ \\
\hline Annularia asteris & Annularia asteris & & \\
\hline Annularia fertilis & & Annularia latifolia pars & Asterophyllites latifolia pars \\
\hline Annularia galioides & Annularia latifolia & $\begin{array}{l}\text { Annularia latifolia pars }+ \\
\text { Annularia latifolia var. minor }\end{array}$ & Annularia sphenophylloides \\
\hline Annularia inflata & Annularia stellata & $\begin{array}{l}\text { Annularia longifolia mutation } \\
\text { leavitti }\end{array}$ & \\
\hline Annularia latifolia & Annularia latifolia & & Annularia latifolia pars \\
\hline \multicolumn{4}{|l|}{ Annularia microphylla } \\
\hline Annularia pseudostellata & Annularia acicularis & & \\
\hline Annularia radiata & Annularia acicularis pars + Annularia radiato & $\begin{array}{l}\text { Annularia acicularis }+ \\
\text { Asterophyllites lentus }\end{array}$ & $\begin{array}{l}\text { Asterophyllites acicularis pars }+ \\
\text { Asterophyllites lenta }\end{array}$ \\
\hline Annularia ramosa & $\begin{array}{c}\text { Annularia aculeata pars }+ \text { Annularia acicularis } \\
\text { pars }\end{array}$ & & \\
\hline Annularia stopesiae & $\begin{array}{c}\text { Annlaria stellata forma longifolia }+ \text { Annularia } \\
\text { pseudostellata }\end{array}$ & & \\
\hline Asterophyllites charaeformis & $\begin{array}{c}\text { Asterophyllites charaeformis }+ \text { Annularia aculeata } \\
\text { pars }+ \text { Asterophyllites grandis pars }\end{array}$ & Asterophyllites parvulus & Asterophyllites parvula \\
\hline Asterophyllites grandis & $\begin{array}{c}\text { Asterophyllites grandis pars }+ \text { Annularia aculeata } \\
\text { pars }\end{array}$ & & Asterophyllites acicularis pars \\
\hline Asterophyllites lindleyanus & Asterophyllites equisetiformis pars & & Asterophyllites trinervis \\
\hline Asterophyllites longifolius & Asterophyllites longifolius & $\begin{array}{l}\text { Asterophyllites longifolius }+ \\
\text { Asterophyllites fasciculatus }+ \\
\text { Asterophyllites? fissus }\end{array}$ & \\
\hline
\end{tabular}




\section{REFERENCES}

Abbott, M.L. 1958. The American species of Asterophyllites, Annularia, and Sphenophyllum. Bulletins of American Paleontology, 38 (174), pp. 289-390.

Álvarez-Vázquez, C. 1995. Macroflora del Westfaliense inferior de la cuenca de Peñarroya-Belmez-Espiel (Córdoba). Unpublished Ph. D. Thesis, Departamento de Geología, Universidad de Oviedo, 393 p.

Álvarez-Vázquez, C. 1999. Nuevos datos aportados por la macroflora a la datación y conocimiento de la cuenca carbonífera de Peñarroya-Belmez-Espiel (Córdoba, SO España). Trabajos de Geología, 21 (Volumen Homenaje a J. Truyols), pp. 37-46.

Álvarez-Vázquez, C. and Wagner, R.H. 2014. Lycopsida from the lower Westphalian (Middle Pennsylvanian) of the Maritime Provinces, Canada. Atlantic Geology, 50, pp. 167-232. https://doi.org/10.4138/atlgeol.2014.011

Amerom, H.W.J. van 1973. Gibt es Cecidien im Karbon bei Calamiten und Asterophylliten? Compte Rendu, Septième Congrès International de Stratigraphie et de Géologie du Carbonifère, Krefeld 1971, II, 63-83.

Andrews, E.B. 1875. Description of Fossil Plants from Lower Carboniferous Strata. In Report of the Geological Survey of Ohio, II. Geology and Paleontology, Pt. II. Paleontology, pp. 413-426.

Arnold, C.A. 1934. A Preliminary Study of the Fossil Flora of the Michigan Coal Basin. Contributions from the Museum of Paleontology, University of Michigan, IV (11), pp. 77-203.

Arnold, C.A. 1941. Some Paleozoic Plants from Central Colorado and their Stratigraphic Significance. Contributions from the Museum of Paleontology, University of Michigan, VI (4), pp. 59-70.

Arnold, C.A. 1949. Fossil Flora of the Michigan Coal Basin. Contributions from the Museum of Paleontology, University of Michigan, VII (9), pp. 131-269.

Artis, E.T. 1825. Antediluvian Phytology, as illustrated by a Collection of the Fossil Remains of Plants peculiar to the Coal Formation of Great Britain. London, pp. 1-24, pls I-XXIV.

Ash, S. and Tidwell, W.D. 1982. Notes on the Upper Paleozoic plants of Central New Mexico. New Mexico Geological Society Guidebook, 33rd Field Conference, Albuquerque County, II, pp. 245-248.

Barthel, M. 2000. Annularia stellata oder Annularia spinulosa?. Veröffentlichungen Naturkundemuseum Erfurt, 19, pp. 37-42.

Bashforth, A.R. 2005. Late Carboniferous (Bolsovian) macroflora from the Barachois Group, Bay St. George Basin, southwestern Newfoundland, Canada. Palaeontographica Canadiana, 24, pp. 1-123.

Bashforth, A.R. and Nelson, W.J. 2015. A Middle Pennsylvanian macrofloral assemblage from below the
Rock Island (No. 1) Coal Member, Illinois: Resolving the Bolsovian-Asturian boundary in the Illinois Basin. Review of Palaeobotany and Palynology, 222, pp. 67-83. https://doi.org/10.1016/j.revpalbo.2015.07.003

Bashforth, A.R., Cleal, C.J., Gibling, M.R., Falcon-Lang, H.J., and Miller, R.F. 2014. Paleoecology of Early Pennsylvanian vegetation on a seasonally dry tropical landscape (Tynemouth Creek Formation, New Brunswick, Canada). Review of Palaeobotany and Palynology, 200, pp. 229263. https://doi.org/10.1016/j.revpalbo.2013.09.006

Bassett, M.G. and Edwards, D. 1982. Fossil Plants from Wales. Amgueddfa, Bulletin of the National Museum of Wales, Geological Series, 2, pp. 1-42. https://doi. org/10.1002/gj.3350020102

Basson, P.W. 1968. The Fossil Flora of the Drywood Formation of Southwestern Missouri. University of Missouri Studies, XLIV, pp. 1-10.

Bell, W.A. 1938. Fossil Flora of Sydney Coalfield, Nova Scotia. Geological Survey of Canada, Memoir 215, pp. 1-334. https://doi.org/10.4095/101646

Bell, W.A. 1940. The Pictou Coalfield, Nova Scotia. Canada Department of Mines and Resources, Mines and Geology Branch, Geological Survey, Memoir 225, pp. 1-161.

Bell, W.A. 1944. Carboniferous rocks and fossil floras of northern Nova Scotia. Canada Department of Mines and Resources, Mines and Geology Branch, Geological Survey, Memoir 238, pp. 1-119. https://doi.org/10.4095/119859

Bell, W.A. 1962. Flora of Pennsylvanian Pictou Group of New Brunswick. Geological Survey of Canada, Bulletin 87, pp. 1-71. https://doi.org/10.4095/100605

Bell, W.A. 1966. Illustrations of Canadian Fossils. Carboniferous plants of eastern Canada. Geological Survey of Canada, Paper 66-11, pp. 1-76. https://doi. org/10.4095/100977

Blake, B.M. 1997. Revised Lithostratigraphy and Megafloral Biostratigraphy of the New River and Kanawha Formations (Pottsville Group: Lower and Middle Pennsylvanian) in Southern West Virginia. Unpublished M.Sc. Thesis, West Virginia University, Morgantown, pp. 1-149.

Blake, B.M., Cross, A.T., Eble, C.F., Gillespie, W.H., and Pfefferkorn, H.W. 2002. Selected plant megafossils from the Carboniferous of the Appalachian region, eastern United States: geographic and stratigraphic distribution. In Carboniferous and Permian of the World, Proceedings XIV International Congress Carboniferous and Permian Stratigraphy, Calgary, Alberta 1999. Edited by L.V. Hills, C.M. Henderson and E.W. Bamber. Canadian Society of Petroleum Geologists, Memoir 19, pp. 259-335.

Boersma, M. 1972. The hetereogeneity of the form genus Mariopteris Zeiller. A comparative morphological study with special reference to the frond composition of West-European species. Text: pp. 1-172. Atlas: pls 1-43. Privately printed, Universiteit Utrecht.

Boulay, N. 1876. Le terrain houiller du Nord de la France 
et ses végétaux fossiles. Thèse de Géologie, Faculté des Sciences de Caen, Imprimerie Lefebvre-Ducrocq, Lille, $74 \mathrm{p}$.

Boureau, E. 1964. Traité de Paléobotanique. T. III: Quatrième Embranchement. Sphenophyta. Masson et Cie, Paris, pp. 11-477.

Brongniart, A. 1822. Sur la classification et la distribution des végétaux fossiles en général, et sur ceux des terrains de sédiment supérieur en particulier. Mémoires Muséum d'Histoire naturelle de Paris, 8, pp. 203-348.

Brongniart, A. 1828a. Prodrome d'une Histoire des Végétaux fossiles. Paris, F.G. Levrault, 225 p.

Brongniart, A. 1828b-1838. Histoire des végétaux fossiles, ou Recherches botaniques et géologiques sur les végétaux renfermés dans les diverses couches du globe. Texte: I (1828-1837) - 1 (1828): i-xii, 1-80; 2 (1828): 81-136; 3 (1829): 137-168; 4 (1830): 169-208; 5 (1831): 209-248; 6 (1831): 249-264; 7 (1833): 265-288; 8 (1834): 289-312; 9 (1834): 313-316; 10 (1836): 337-368; 11 (1837): 369-416; 12 (1837): 417-488. II (1837-1838) - 13 (1837): 1-24; 14 (1838): 25-56; 15 (1838): 57-72; Atlas: I - Pls 1-166; II Pls 1-30. Facsimile Edition W. Junk, Berlin (1915).

Canright, J.E. 1959. Fossil plants of Indiana. Indiana Department of Conservation, Geological Survey, Report of Progress 14, pp. 1-45.

Cleal, C.J. 1981. The Ravenhead Collection of Fossil Plants. The Amateur Geologist, IX (11), pp. 12-23.

Cleal, C.J. 1988. Fossils explained 9: Coal Measures plants. Geology Today, May-June, pp. 102-103. https://doi. org/10.1111/j.1365-2451.1988.tb00565.x

Cleal, C.J. and Shute, C.H. 2016. A new late Carboniferous calamitacean sphenophyte from South Wales, United Kingdom. Spanish Journal of Palaeontology, 31 (1), pp. 25-40.

Cleal, C.J., Laveine, J.-P., and Shute, C.H. 1996. Architecture of the upper Carboniferous pteridosperm frond Macroneuropteris macrophylla. Palaeontology, 39 (3), pp. 561-582.

Cleal, C.J., Scanu, G.G., Buosi, C., Pittau, P., and Kustatscher, E. 2016. Middle Pennsylvanian vegetation of the San Giorgio Basin, southern Sardinia (Italy). Geological Magazine, pp. 1-16. https://doi.org/10.1017/ S0016756816000765

Crépin, F. 1880. Notes Paléophytologiques. Première note. Observations sur les Sphenophyllum. Compte rendu de la Société royale de botanique de Belgique, XIX, $2^{\mathrm{e}}$ partie, pp. 1-10.

Cridland, A.A. 1968. Carpannularia re-examined. The Palaeobotanist, 17 (1), pp. 97-100.

Cridland, A.A., Morris, J.E., and Baxter, R.W. 1963. The Pennsylvanian plants of Kansas and their stratigraphic significance. Palaeontographica, Abt. B, 112 (1-3), pp. 58-92.

Crookall, R. 1969. Fossil Plants of the Carboniferous Rocks of Great Britain. (Second Section). Memoirs of the Geological Survey of Great Britain, Palaeontology, IV. Part 5, pp. 573-792, pls CVII-CL.

Cross, A.T., Gillespie, W.H., and Taggart, R.E. 1996. Upper Paleozoic vascular plants. In Fossils of Ohio. Edited by R.M. Feldmann and M. Hackathorn. Department of Natural Resources, Division of Geological Survey, Bulletin 70, pp. 396-479.

Darrah, W.C. 1969. A critical review of the Upper Pennsylvanian floras of Eastern United States with notes on the Mazon Creek Flora of Illinois. Privately printed, Catalog Card Number 74-113602, Library of Congress, Washington, $220 \mathrm{p}$.

Dawson, J.W. 1861. On the Pre-carboniferous Flora of New Brunswick, Maine, and Eastern Canada. The Canadian Naturalist and Geologist, VI (3), pp. 161-180.

Dawson, J.W. 1862. On the Flora of the Devonian Period in North-Eastern America. Quarterly Journal Geological Society of London, XVIII, pp. 296-330. https://doi. org/10.1144/GSL.JGS.1862.018.01-02.42

Dawson, J.W. 1868. Acadian Geology. The Geological Structure, Organic Remains, and Mineral Resources of Nova Scotia, New Brunswick, and Prince Edward Island. London ( $2^{\text {nd }}$ edition, 1891), MacMillan and Co., London, $694 \mathrm{p}$.

Dawson, J.W. 1871. The Fossil Plants of the Devonian and Upper Silurian Formations. Geological Survey of Canada, Report, pp. 1-92. https://doi.org/10.4095/216073

Dilcher, D.L. and Lott, T.A. 2005. Atlas of Union Chapel Mine Fossil Plants. In Pennsylvanian Footprints in the Black Warrior Basin of Alabama. Edited by R.J. Buta, A.K. Rindsberg, and D.C. Kopaska-Merkel. Alabama Paleontological Society, Monograph, 1, pp. 339-365.

Dilcher, D.L., Lott, T.A., and Axsmith, B.J. 2005. Fossil Plants from the Union Chapel Mine, Alabama. In Pennsylvanian Footprints in the Black Warrior Basin of Alabama. Edited by R.J. Buta, A.K. Rindsberg, and D.C. Kopaska-Merkel. Alabama Paleontological Society, Monograph, 1, pp. 153168.

DiMichele, W. and Dolph, G. 1981. Compression Floras of the Upper Mansfield/Lower Brazil and Upper Staunton Formation in Parke and Clay Counties, Indiana. Thirtysecond Annual AIBS Meeting, Bloomington, Indiana. Field Trip 2, Guidebook to Pennsylvanian Plant Localities, pp. 1-6.

DiMichele, W.A., Wagner, R.H., Bashforth, A.R., and Álvarez-Vázquez, C. 2013. An update on the flora of the Kinney Quarry of Central New Mexico (Upper Pennsylvanian), its preservational and environmental significance. In The Carboniferous- Permian Transition in Central New Mexico. Edited by S.G. Lucas, W.J. Nelson, W.A. DiMichele, J.A. Spielmann, K.Krainer, J.E. Barrick, S. Elrick, and S. Voigt. New Mexico Museum of Natural History and Science, Bulletin 59, pp. 289-325. 
Eggert, D.L. and Phillips, T.L. 1982. Environments of Deposition - Coal Balls, Cuticular Shale, and Gray-Shale Floras in Fountain and Parke Counties, Indiana. State of Indiana, Department of Natural Resources, Geological Survey, Special Report 30, pp. 1-43.

Elias, M.K. 1931. On a Seed-bearing Annularia and on Annularia Foliage. The University of Kansas Science Bulletin, XX (5), pp. 115-148.

Falcon-Lang, H.J. 2006. Vegetation ecology of Early Pennsylvanian alluvial fan and piedmont environments in southern New Brunswick, Canada. Palaeogeography, Palaeoclimatology, Palaeoecology, 233, pp. 34-50. https:// doi.org/10.1016/j.palaeo.2005.09.005

Falcon-Lang, H.J. and Miller, R.F. 2007. Marie Stopes and the Fern Ledges of Saint John, New Brunswick. In The Role of Women in the History of Geology. Edited by C.V. Burer and B. Higgs. Geological Society, London, Special Publications, 281, pp. 227-245. https://doi.org/10.1144/ sp281.13

García-Loygorri, A. and Ortuño Aznar, G. 1969. Estudio geológico de la cuenca carbonífera de Villanueva del Río y Minas (Sevilla). III Jornadas y Primeras Internacionales Minero-Metalúrgicas, Gijón 1967, pp. 821-864.

Gastaldo, R.A. 1977. A Middle Pennsylvanian nodule flora from Carterville, Illinois. In Geobotany. Edited by R.C. Romans. Plenum Publishing Corporation, New York, pp. 133-155. https://doi.org/10.1007/978-1-4757-1674-0_8

Geinitz, H.B. 1855. Die Versteinerungen der Steinkohlenformation in Sachsen. Leipzig, $61 \mathrm{p}$.

Gillespie, W.H. and Clendening, J.A. 1962. A Lower Kittanning Flora from Northern West Virginia. Proceedings West Virginia Academy of Science, 34, pp. 125-132.

Gillespie, W.H. and Crawford, T.J. 1985. Plant megafossils from the Carboniferous of Georgia, U.S.A. Compte Rendu $10^{\mathrm{e}}$ Congrès International de Stratigraphie et de Géologie du Carbonifère, Madrid 1983, 2, pp. 247-256.

Gillespie, W.H. and Latimer, I.S. 1960. A guide to the common fossil plants of West Virginia. West Virginia Geological and Economic Survey, Educational Series, June 1960, pp. 1-59.

Gillespie, W.H. and Pfefferkorn, H.W. 1979. Distribution of commonly occurring plant megafossils in the proposed Pennsylvanian System stratotype. In Proposed Pennsylvanian System stratotype. Virginia and West Virginia. Edited by K.J. Englund, H.H. Arndt, and T.W. Henry. Field Trip No. 1. Ninth Congress of Carboniferous Stratigraphy and Geology. American Geological Institute Selected Guidebook Series, No. 1, pp. 87-97.

Gillespie, W.H. and Pfefferkorn, H.W. 1986. Plant Fossils of the New River Gorge, West Virginia. Proceedings of the West Virginia Academy of Science, Papers of the FiftyNinth Annual Session, Mining and Geology Section, 56 $(2,3,4)$, pp. $124-135$.
Gillespie, W.H. and Rheams, L.J. 1985. Plant megafossils from the Carboniferous of Alabama, U.S.A. Compte Rendu $10^{\mathrm{e}}$ Congrès International de Stratigraphie et de Géologie du Carbonifère, Madrid 1983, 2, pp. 191-202.

Gillespie, W.H., Latimer, I.S., and Clendening, J.A. 1966. Plant fossils of West Virginia. West Virginia Geological and Economic Survey, Educational Series, January 1966, pp. 1-131.

Gillespie, W.H., Clendening, J.A., and Pfefferkorn, H.W. 1978. Plant Fossils of West Virginia and Adjacent Areas. West Virginia Geological and Economic Survey, Educational Series ED-3A, pp. 1-172.

Gillespie, W.H., Crawford, T.J., and Waters, J.A. 1989. Plant fossils of the Pennsylvanian System of Georgia. $38^{\text {th }}$ Annual Meeting, Southeastern Section, The Geological Society of America, Guidebook Addendum, pp. 1-13.

Göppert, H.R. 1844. Flora von Schlesien preussischen und österreichischen Antheils. Friedrich Wimmer, Breslau, $279 \mathrm{p}$.

Göppert, H.R. 1848. Index palaeontologicus, oder Uebersicht der bis jetzt bekannten fossilen Organismen, unter Mitwirkung von Heinrich Robert Göppert und Hermann Meyer bearbeitet. E. Schweizerbart, Stuttgart.

Göppert, H.R. 1852. Fossile Flora des Übergangsgebirges. Verhandlungen der Kaiserlichen Leopoldinisch-Carolinischen Akademie der Naturforscher. Breslau und Bonn, $299 \mathrm{p}$.

Göppert, H.R. 1864. Die fossile Flora der Permischen Formation. Beiträge zur Naturgeschichte der Vorwelt. Palaeontographica, XII, pp. 1-316.

Gothan, W. 1941. Die Steinkohlenflora der westlichen paralischen Steinkohlenreviere Deutschlands (4. Lieferung). Abhandlungen Reichsstelle für Bodenforschung (N.F.), 196, pp. 1-54.

Gothan, W. and Remy, W. 1957. Steinkohlenpflanzen. Leitfaden zum Bestimmen der wichtigsten pflanzlichen Fossilien des Paläozoikums im rheinisch-westfälischen Steinkohlengebiet. Verlag Glückauf GMBH, Essen, 248 p.

Gothan, W., Leggewie, W., Schonefeld, W., and Remy, W. 1959. Die Steinkohlenflora der westlichen paralischen Steinkohlenreviere Deutschlands. Geologisches Jahrbuch, Beiheft, 36 (6), pp. 1-90.

Grand'Eury, F.C. 1877. La flore carbonifère du Départment de la Loire et du centre de la France, étudiée aux trois points de vue botanique, stratigraphique et géognostique. Mémoires présentés par divers savants à l'Académie des Sciences de l'Institut de France, XXIV (1), 624 p.

Gutbier, A. von 1837. Isis von Oken. Leipzig, 435 p.

Gutbier, A.von 1849. Die Versteinerungen des Rothliegenden in Sachsen. Dresden and Leipzig, 30 p.

Guthörl, P. 1957. Querschnitt durch das Saar-Lothringische Karbon. 4. Pflanzen- und Tierreste aus den Aufschlüssen Ziegelei Müller (Wellesweiler) und den Bohrlöchern Wellesweiler (276), Hangard 1 (328) und Hangard 2 (340) 
sowie ihre Bedeutung für die Klärung der Stratigraphie und Tektonik im östlichen Teil des Saarbrücker Steinkohlengebietes. Palaeontographica, Abt. B, 102 (13), pp. 1-70.

Janssen, R.E. 1940. Some Fossil Plant Types of Illinois. A Restudy of the Lesquereux Types in the Worthen Collection of the Illinois State Museum, Augmented By Descriptions of New Species From Mazon Creek. Illinois State Museum, Scientific Papers, I, pp. 1-124.

Janssen, R.E. 1957. Leaves and Stems from Fossil Forests. A Handbook of the Paleobotanical Collections in the Illinois State Museum. Illinois State Museum, Popular Science Series, I, pp. 1-190. (First edition, 1939.)

Jongmans, W.J. 1911. Anleitung zur Bestimmung der Karbonpflanzen West-Europas mit besonderer Berücksichtigung der in den Niederlanden und den benachbarten Ländern gefundenen oder nochzuerwartenden Arten.

I Band. Thallophytae, Equisetales, Sphenophyllales. Mededeelingen Rijksopsporing van Delfstoffen, 3, pp. $1-482$.

Jongmans, W.J. 1914a. Fossilium Catalogus. II: Plantae. Pars 4: Equisetales I: Actinopteris, Anarthrocanna, Annularia, Annulariopsis, Aphyllostachys. Ed. W. Junk, Netherlands, pp. 3-53.

Jongmans, W.J. 1914b. Fossilium Catalogus. II: Plantae. Pars 4: Equisetales III: Asterophyllites bis Calamitea. Ed. W. Junk, Netherlands, pp. 89-193.

Jongmans, W.J. 1928. Stratigraphie van het Karboon in het algemeen en van Limburg in het bijzonder. Geologisch Bureau voor het Nederlandsche Mijngebied te Heerlen, Mededeeling 6, pp. 1-50.

Jongmans, W.J. 1932. Hoe Zuid-Limburg er in den Karboontijd uitgezien heeft. Mijnen-Nummer V.V.V., Heerlen, pp. 1-16.

Jongmans, W.J. 1937. Comparison of the floral sucession in the Carboniferous of West Virginia with Europe. With the collaboration of W. Gothan and some additional notes by W.C. Darrah. Compte Rendu $2^{\mathrm{e}}$ Congrès pour l'avancement des études de Stratigraphie et de Géologie du Carbonifère, Heerlen 1935, I, pp. 393-415.

Jongmans, W.J. and Dijkstra, S.J. 1969. Fossilium Catalogus. II: Plantae. Pars 75: Sphenophyta. Ed. W. Junk, Netherlands, pp. 3-105.

Jongmans, W.J. and Gothan, W. 1934. Florenfolge und vergleichende Stratigraphie des Karbons der östlichen Staaten Nord-Amerika’s. Vergleich mit West-Europa. Geologisch Bureau voor het Nederlandsche Mijngebied te Heerlen, Jaarverslag over 1933, pp. 17-44.

Jongmans, W.J. and Kukuk, P. 1913. Die Calamariaceen des Rheinisch-Westfälischen Kohlenbeckens. (Mitteilungen aus dem geologischen Museum der Westfälischen Berggewerkschaftskasse, Bochum). Mededeelingen van 's Rijks Herbarium, Leiden, 20, Tafn, pp. 1-22.

Josten,K.-H.1991.DieSteinkohlen-Floren Nordwestdeutsch- lands. Fortschritte Geologie von Rheinland und West falen, 36, Textband: 1-434; Tafelband: 1-11, Tafn 1-220. Kidston, R. 1884. On the Fructification of Zeilleria (Sphenopteris) delicatula, Sternb., sp.; with Remarks on Urnatopteris (Sphenopteris) tenella, Brongt., and Hymenophyllites (Sphenopteris) quadridactylites, Gutbier, sp. Quarterly Journal of the Geological Society, London, XL, pp. 590-598. https://doi.org/10.1144/GSL.JGS.1884. 40.01-04.49

Kidston, R. 1886. Catalogue of the Palaeozoic Plants in the Department of Geology and Palaeontology, British Museum (Natural History). Harrison and Sons, London, $288 \mathrm{p}$.

Kidston, R. 1891. Notes on the Palaeozoic Species mentioned in Lindley and Hutton's "Fossil Flora". Proceedings of the Royal Physical Society, Edinburgh, X (1889-1890), pp. 345-391.

Kidston, R. 1893. On the Fossil Plants of the Kilmarnock, Galston, and Kilwinning Coal Fields, Ayrshire. Transactions of the Royal Society of Edinburgh, XXXVII, II (16), pp. 307-358.

Kidston, R. 1901. The Flora of the Carboniferous Period. Proceedings of the Yorkshire Geological and Polytechnic Society, New Series, XIV (II), pp. 189-230. https://doi. org/10.5962/bhl.title.7792

Kidston, R. 1911. Les végétaux houillers recueillis dans le Hainaut Belge et se trouvant dans les Collections du Musée royal d'Histoire naturelle à Bruxelles. Imprimerie Polleunis \& Ceuterick, Bruxelles, 282 p.

Kidston, R. 1914. On the Fossil Flora of the Staffordshire Coal Fields. Part III. The Fossil Flora of the Westphalian Series of the South Staffordshire Coal Field. Transactions of the Royal Society of Edinburgh, L, part I (5), pp. 73190.

Kidston, R., Cantrill, T.C., and Dixon, E.E.L. 1917. The Forest of Wyre and the Titterstone Clee Hill Coal Fields. Transactions of the Royal Society of Edinburgh, LI, part IV (27), pp. 999-1084.

Kotasowa, A. 1968. The flora of the productive Carboniferous in the north-eastern part of the Upper Silesian Coal Basin (Dąbrowa District). Instytut Geologiczny Prace, LII, pp. 1-88, Tab. I-XXXIII. (In Polish with English summary.)

Kvaček, J. and Straková, M. 1997. Catalogue of fossil plants described in works of Kaspar M. Sternberg. National Museum, Prague, pp. 1-201, pl. A; pls 1-67.

Langford, G. 1958. The Wilmington Coal Flora From a Pennsylvanian Deposit in Will County, Illinois. Earth Science Club of Northern Illinois, Esconi Associates, Illinois, $360 \mathrm{p}$.

Laveine, J.-P. 1989. Guide Paléobotanique dans le Terrain Houiller Sarro-Lorraine. Documents des Houillères du Bassin de Lorraine. Texte: 1-154; Atlas: 1-64.

Leary, R.L. 1976. Inventory of Type and Figured Paleo- 
botanical Specimens in the Illinois State Museum. Illinois State Museum, Inventory of Geological Collections, $n^{\circ}$ 2, Part 2, pp. 1-64.

Leary, R.L. 1981. Early Pennsylvanian Geology and Paleobotany of the Rock Island County, Illinois, Area. Part 1: Geology. Illinois State Museum, Reports of Investigations, 37, pp. 1-88.

Leary, R.L. and Pfefferkorn, H.W. 1977. An Early Pennsylvanian Flora with Megalopteris and Noeggerathiales from West-Central Illinois. Illinois State Geological Survey, Circular 500, pp. 1-77.

Ledran, C. 1966. Contributions à l'étude des feuilles de Cordaitales. Thèse de doctorat, Faculté des Sciences de l'Académie de Reims. Imprimerie du Nord-Est, Reims, $155 \mathrm{p}$.

Leggewie, W. and Schonefeld, W. 1961. Die Calamariaceen der Westfal-Schichten im Ruhrkarbon. Veröffentlichung der montangeologischen Arbeitsgemeinschaft für die westdeutschen Steinkohlengebiete. Palaeontographica, Abt. B, 109 (1-4), pp. 1-44.

Lesquereux, L. 1860. Botanical and Paleontological Report on the Geological State Survey of Arkansas. In Owen, D.D., Second Report of a Geological Reconnaissance of the Middle and Southern Counties of Arkansas, Philadelphia, pp. 308-317.

Lesquereux, L. 1870. Report on the Fossil Plants of Illinois. In Geological Survey of Illinois. IV. Geology and Paleontology. Edited by A.H. Worthen. Part I: A.H. Worthen, H.M. Bannister, F.H. Bradley, and H.A. Green. Geology, pp. 1-342. Part II: Paleontology of Illinois; Section I. J.S. Newberry \& A.H. Worthen. Description of Fossil Vertebrates, pp. 346-374, pls I-IV; Section II. L. Lesquereux. Description of Plants, pp. 377-508.

Lesquereux, L. 1879-1884a. Description of the Coal Flora of the Carboniferous Formation in Pennsylvania and throughout the United States. Second Geological Survey of Pennsylvania. Report of Progress. Text - I (1880): 1-354; II (1880): 355-694, pls LXXXVI, LXXXVII; III (1884): 695-977, pls LXXXVIII-CXI. Atlas (1879), pls A, B; pls I-LXXXV.

Lesquereux, L. 1884b. Principles of Paleozoic Botany. Indiana Report State Geologist, 13 (1883), pt. II, Paleontology, pp. 6-106.

Libertín, M., Dašková, J., Opluštil, S., Bek, J., and Edress, N. 2009. A palaeoecological model for a vegetated early Westphalian intramontane valley (Intra-Sudetic Basin, Czech Republic). Review of Palaeobotany and Palynology, 155, pp. 175-203. https://doi.org/10.1016/j. revpalbo.2008.07.002

Lindley, J. and Hutton, W. 1831-1837. The Fossil Flora of Great Britain; or, Figures and Descriptions of the Vegetable Remains found in a Fossil State in this Country. I (1831-1833) - 1831: 1-47, pls 1-14; 1832: 48-166, pls 15-59; 1833: 167-224, pls 60-79; II (1833-1835)-
1833: 1-56, pls 80-99; 1834: 57-156, pls 100-137; 1835 : 157-208, pls 138-156; III (1835-1837) - 1835: 1-72, pls 157-176; 1836: 73-122, pls 177-194; 1837: 123-208, pls 195-230. James Ridgway and Sons, London.

Lyons, P.C., Zeissner, C.R., Barwood, H.L., and Adinolfi, F.G. 1985. North American and European megafloral correlations with the upper part of the Pottsville Formation of the Warrior coal field; Alabama, U.S.A. Compte Rendu $10^{\mathrm{e}}$ Congrès International de Stratigraphie et Géologie du Carbonifère, Madrid 1983, 2, pp. 203-245, pls I-XIV.

Mamay, S. and Mapes, G. 1992. Early Virgilian plant megafossils from the Kinney Brick Company Quarry, Manzanita Mountains, New Mexico. In Geology and Paleontology of the Kinney Brick Quarry, Late Pennsylvanian, central New Mexico. Edited by J. Zidek. New Mexico Bureau of Mines \& Mineral Resources, Bulletin 138, pp. 61-85.

Matthew, G.F. 1906a. A Review of the Flora of the Little River Group. Transactions of the Royal Society of Canada, XII (IV), pp. 99-149.

Matthew, G.F. 1906b. New Species and a New Genus of Devonian Plants. Bulletin of Natural History Society of New Brunswick, XXIV, V (IV), pp. 393-398.

Miller, R.F. 1987. George Frederic Matthew (1837-1923). Victorian Science in Saint John. NBM News, AugustSeptember 1987, pp. 3-26.

Moore, R.C., Elias, M.K., and Newell, N.D. 1936. A "Permian" flora from the Pennsylvanian rocks of Kansas. The Journal of Geology, XLIV (1), pp. 1-31. https://doi. org/10.1086/624391

Moore, L.R., Neves, R., Wagner, R.H., and WagnerGentis, C.H.T. 1971. The stratigraphy of Namurian and Westphalian rocks in the Villamanín area of northern León, NW Spain. In The Carboniferous of Northwest Spain. Edited by R.H. Wagner. Trabajos de Geología, 3, pp. 307-363.

Němejc, F. 1963. Paleobotanika II. Nakladatelstvi Československé Akademie Věd, Praha, 529 p. (In Czech.)

Noé, A.C. 1925. Pennsylvanian flora of Northern Illinois. State Geological Survey, Bulletin 52, pp. 1-113.

Novik, E.O. 1952. Coal Measure Flora of the European Part of SSSR. Akademia Nauk SSSR, I, pp. 1-468. (In Russian).

Oleksyshyn, J. 1976. Fossil Plants of Pennsylvanian Age from Northwestern Narragansett Basin. Geological Society of America, Memoir 146, pp. 143-180.

Pfefferkorn, H.W. and Gillespie, W.H. 1977. Plant Fossils in the Proposed Pennsylvanian System Stratotype. In A Field Guide to Proposed Pennsylvanian System Stratotype, West Virginia. Edited by K.J. Englund, H.H. Arndt, W.H. Gillespie, T.W. Henry, and H.W. Pfefferkorn. AAPG/ SEPM Washington Convention Pre-Meeting Field Trip, June 1977, pp. 21-26.

Pfefferkorn, H.W. and Gillespie, W.H. 1981. Biostratigraphic significance of plant megafossils near the Mississippian- 
Pennsylvanian boundary in southern West Virginia and southwestern Virginia. In GSA Cincinnati '81 Field Trip Guidebooks. Volume I: Stratigraphy, Sedimentology. Edited by T.G. Roberts. American Geological Institute, pp. 159-164.

Potonié, H. 1892. Ueber einige Carbonfarne. III. Teil. Abhlandlungen Königlich Preussischen geologischen Landesanstalt und Bergakademie zu Berlin, XII (für 1891), pp. 1-36.

Potonié, H. 1893. Ueber das Rothliegende des Thüringer Waldes. II. Die Flora des Rothliegenden von Thüringen. Abhandlungen der Königlich Preussischen geologischen Landesanstalt, Neue Folge, 9, pp. 1-298.

Potonié, H.1899. Lehrbuch der Pflanzenpalaeontologie mit besonderer Rücksicht auf die Bedürfnisse des Geologen. Berlin, 1897-1899, 402 p.

Pšenička, J. and Opluštil, S. 2011. Fossil flora from the Ujezd u Svatého Křiže coalfield (Bolsovian, Pennsylvanian), Radnice Basin, Czech Republic. Folia, 45 (1-2), pp.61-93.

Purkyňová, E. 1962. Flóra produktivního karbonu ostravskokarvinského revíru. Pracovní metody geologické služby, 3, pp. 1-116. (In Czech.)

Purkyňová, E. 1997. Zjišš̌ní makroflóry karvinského souvrství v jablunkovské depresi (podbeskydská část hornoslezské pánve, Česká republika). Časopis Slezského Muzea Opava (A), 46, pp. 193-196. (In Czech.)

Purkyňová, E. 2000. Floristické novinky z karvinského souvrství hornoslezské uhelné pánve (Česká republika). Časopis Slezského Muzea Opava (A), 49, pp. 1-5. (In Czech.)

Read, C.B. 1934. A flora of Pottsville age from the Mosquito Range, Colorado. U.S. Geological Survey, Professional Paper 185-D, pp. 79-96.

Remy, W. and Remy, R. 1959. Pflanzenfossilien. Ein Führer durch die Flora des limnisch entwickelten Paläozoikums. Akademie Verlag, Berlin, 285 p.

Remy, W. and Remy, R. 1975. Calamites asteropilosus n. sp. und Annularia asteropilosa n. sp. aus dem unteren Westfal A des Ruhrkarbons. Argumenta Palaeobotanica, 4, pp. 135-138.

Remy, W. and Remy, R. 1977. Die Floren des Erdaltertums. Einführung in Morphologie, Anatomie, Geobotanik und Biostratigraphie der Pflanzen des Paläophytikums. Verlag Glückauf GMBH, Essen, 468 p.

Renier, A. 1910. Documents pour l'étude de la Paléontologie $\mathrm{du}$ Terrain houiller. Imprimerie H. Vaillant-Carmanne, Liège, pp. 1-26, pls 1-118.

Renier, A., Stockmans, F., Demanet, F., and Straelen, V. van. 1938. Flore et Faune houillères de la Belgique. Introduction à l'Étude paléontologique du Terrain houiller. Musée royal d'Histoire naturelle de Belgique, Bruxelles. Texte: 1-317; Planches: pls 1-144.

Sauveur, M. 1848. Végétaux fossiles des Terrains houillers de la Belgique. Académie Royale des Sciences, des Lettres et des Beaux-Arts de Belgique, pls I-XXXVI.

Schenk, A. 1883. Pflanzen aus der Steinkohlen-Formation. In V. Richthofen. China, Band 4 (pt 2), pp. 211-269.

Schimper, W.P. 1869-1874. Traité de Paléontologie Végétale ou la Flore du Monde Primitif dans ses Rapports avec les Formations Géologiques et la Flore du Monde Actuel. Texte - I (1869): 1-738; II (1870-72): 1-966; III (1874): 1-896; Atlas (1874): pls I-CX. J.B. Baillière et Fils, Paris.

Schimper, W.P. 1880. Handbuch der Palaeontologie, unter Mittwirkung von Dr A. Schenk, herausgegeben von K.A. Zittel. Bd. II, 2, pp. 153-232.

Schlotheim, E.F. von 1820. Die Petrefactenkunde auf ihrem jetztigen Standpunkte, durch die Beschreibung seiner Sammlung versteinerter und fossiler Überreste des Thierund Pflanzenreichs der Vorwelt erläutert. Gotha, i-lxii (Einleitung), pp. 1-437, Tafn I-XXXVI (Nachträge in 1822; i-xi, 100 p. und 1823, 114 p.).

Sternberg, K. von 1820-1838. Versuch einer geognostischbotanischer Darstellung der Flora der Vorwelt. I (18201825) 1 (1820): 1-24, Tafn I-XIII; 2 (1823): 1-33, Tafn XIV-XXVI; 3 (1824): 1-40, Tafn XXVII-XXXIX; 4 (1825): 1-48, Tafn XL-LIX, Tafn A-E. II (1833-1838) - 5/6 (1833): 1-80, Tafn I-XXVI; 7/8 (1838, Presl): 81-220, Tafn I-LXVIII, Tafn A, B (incl. Corda: Skizzen zur vergleichenden Phytotomie vor- und jetztweltlicher Pflanzenstämme, I-LXXI).

Stockmans, F. and Willière, Y. 1952-1953. Végétaux namuriens de la Belgique. Association pour l'Étude de la Paléontologie et de la Stratigraphie houillères, 13. Texte (1953): 1-382. Atlas (1952): pls I-LVII.

Stockmans, F. and Willière, Y. 1965. Documents paléobotaniques pour l'Étude du Houiller dans le NordOuest de l'Espagne. [Documentos paleobotánicos para el estudio de la geología hullera del Noroeste de España]. Mémoires, Institut Royal des Sciences Naturelles de Belgique, Deuxième Série, fasc. 79, pp. 1-92, pls IXXXVIII.

Stopes, M.C. 1914. The "Fern Ledges" Carboniferous Flora of St. John, New Brunswick. Geological Survey of Canada, Memoir 41 (38 of Geological Series), pp. 1-142, pls IXXV. (Traduction française 1917. Flore carbonifère des "assises à fougères" de Saint-Jean, Nouveau-Brunswick. Geological Survey of Canada, Memoir 41.)

Stur, D. 1875. Beiträge zur Kenntnis der Flora der Vorwelt. Die Culm-Flora des Märisch-Schlesischen Dachschiefers. Abhandlungen der k. k. geologischen Reichsanstalt, VIII (I), pp. 1-106.

Stur, D. 1877. Die Culmflora der Ostrauer und Waldenburger Schichten. Abhandlungen der k. k. geologischen Reichsanstalt, VIII (II), pp. 107-366.

Stur, D. 1883. Zur Morphologie und Systematik der Culmund Carbonfarne. Sitzberichte königlichen Akademie der Wissenschaften, I Abtheilung, LXXXVIII, pp. 633-846 (1-214). 
Stur, D. 1887. Die Carbon-Flora der Schatzlarer Schichten. 2. Die Calamarien der Carbon-Flora der Schatzlarer Schichten. Beiträge zur Kenntniss der Flora der Vorwelt, Band II, Abt. 2, pp. 1-240.

Suckow, A.G. 1784. Beschreibung einiger merkwürdiger Abdrücke von der Art der sogenannten Calamiten. Acta, Historia et Commentationes Academiae electoralis scientiarum et elegantiorum litterarum TheodoroPalatinae, V, pp. 1-355.

Tenchov, Y.G. 1987. Les fossiles de Bulgarie. I.1. Paléozoïque. Flore fossile. Mégaflora. 1. Sphenopsida et Lycopsida. Editions de l'Académie Bulgare des Sciences, pp. 1-165.

Thomas, B.A. and Cleal, C.J. 1994. Plant fossils from the Writhlington Geological Nature Reserve. Proceedings of the Geologists' Association, 105, pp. 15-32. https://doi. org/10.1016/s0016-7878(08)80135-6

Tidwell, W.D. 1967. Flora of Manning Canyon Shale. Part I: A Lowermost Pennsylvanian Flora from the Manning Canyon Shale, Utah, and Its Stratigraphic Significance. Brigham Young University Geology Studies, 14, pp. 1-66.

Tidwell, W.D. 1975. Guide to common fossil plants of western North America. Brigham Young University Press, Provo, pp. 1-197.

Tidwell, W.D., Jennings, J.R., and Call, V.B. 1988. Flora of Manning Canyon Shale, Part III: Sphenophyta. Brigham Young University Geology Studies, 35, pp. 15-32.

Unger, F. 1840. Abhandlung über die Struktur des Calamites und ihre Rangordnung im Gewächreiche. Flora, 2, pp. 654-662.

Unger, F. 1850. Genera et species plantarum fossilium. Vindobonae, $628 \mathrm{p}$.

Wagner, R.H. 2008. Laveineopteris polymorpha from the lower Westphalian (Langsettian) "Fern Ledges" at Saint John, New Brunswick, Canada, and comparison with Laveineopteris hollandica from Europe. Revista Española de Paleontología, 23 (2), pp. 139-156.

Wagner, R.H. and Álvarez-Vázquez, C. 2010. The Carboniferous floras of the Iberian Peninsula: A synthesis with geological connotations. Review of Palaeobotany and Palynology, 162 (3), pp. 239-324. https://doi. org/10.1016/j.revpalbo.2010.06.005

Walton, J. 1936. On the Factors which Influence the External Form of Fossil Plants; with Descriptions of the Foliage of Some Species of the Palaeozoic Equisetalean Genus Annularia Sternberg. Philosophical Transactions of the Royal Society of London, Series B, Biological Sciences, 535 (226), pp. 219-237. https://doi.org/10.1098/ rstb. 1936.0008

Weiss, C.E. 1884. Beiträge zur fossilen Flora. III. SteinkohlenCalamarien. II. Königlich Preussischen geologischen Landesanstalt, V (2), Text: 87-290; Atlas: I-XXVIII.

White, C.A. 1880. Paleontology. Fossils of the Indiana Rocks. State of Indiana, $2^{\text {nd }}$ Annual Report, Department Statistics and Geology, pp. 469-544.
White, D. 1899. Fossil Flora of the Lower Coal Measures of Missouri. United States Geological Survey, Monographs, XXXVII, pp. 1-467.

White, D. 1900. The Stratigraphic Succession of the Fossil Floras of the Pottsville formation in the Southern Anthracite coal field, Pennsylvania. Twentieth Annual Report United States Geological Survey, 1898-1899, pt. II - General Geology and Paleontology, pp. 749-918, pls CLXXX-CXCIII.

Winston, R.B. 1983. A Late Pennsylvanian upland flora in Kansas: systematics and environmental implications. Review of Palaeobotany and Palynology, 40, pp. 5-31. https://doi.org/10.1016/0034-6667(83)90003-9

Wittry, J. 2006. The Mazon Creek Fossil Flora. Earth Science Club of Northern Illinois, Esconi Associates, Illinois, pp. $1-154$.

Wood, H.C. 1860. Contributions to the Carboniferous Flora of the United States. Proceedings of the Academy of Natural Sciences of Philadelphia, pp. 236-240.

Wood, H.C. 1869. A Contribution to the Knowledge of the Flora of the Coal Period in the United States. Transactions of the American Philosophical Society, (N.S.), 13 (3), pp. 341-349.

Wood, J.M. 1963. The Stanley Cemetery Flora (Early Pennsylvanian) of Greene County, Indiana. Indiana Department of Conservation, Geological Survey, Bulletin 29, pp. 1-73.

Zalessky, M.D. 1907a. Contributions à la flore fossile du terrain houiller du Donetz. II. Plantes fossiles de l'Institut géologique de l'Université Impériale de Kharkow et du Musée du Don à Novotcherkask. Bulletins du Comité Géologique, XXVI, pp. 423-494. (In Russian with French summary.)

Zalessky, M.D. 1907b. Contributions à la flore fossile $\mathrm{du}$ terrain houiller du Donetz. I. Plantes fossiles de la collection de V. Domherr. Bulletins du Comité Géologique, XXVI, pp. 351-422, Tab. XXII-XVII. (In Russian with French summary.)

Zeiller, R. 1878-1879. Explication de la carte géologique de la France, publiée par ordre de M. le Ministre des Travaux publiques. Tome IV, Seconde partie. Végétaux Fossiles du Terrain Houiller. Texte (1879): pp. 1-186. Atlas (1878): pls CLIX-CLXXVI.

Zeiller, R. 1883. Fructifications de fougères du terrain houiller. Annales Sciences naturelles, Paris, Botanique, $6^{\mathrm{e}}$ série, XVII, pp. 130-143.

Zeiller, R. 1886-1888. Bassin houiller de Valenciennes. Description de la flore fossile. Études des Gîtes Minéraux de la France, Ministère des Travaux Publics. Texte (1888), pp. 1-729. Atlas (1886): pls I-XCIV.

Zeiller, R. 1892. Bassin Houiller et Permien de Brive. II. Flore Fossile. Études des Gîtes Minéraux de la France, Ministère des Travaux Publics, pp. 1-132.

Zenker, F.C. 1883. Beschreibungvon Galium sphenophylloides 
Zenk. Neues Jahrbuch für Mineralogie, Geognosie, Geologie und Petrefactenkunde, Stuttgart, pp. 398-400.

Zodrow, E.L. and McCandlish, K. 1980. Upper Carboniferous Fossil Flora of Nova Scotia In the Collections of the Nova Scotia Museum, with Special Reference to the Sydney Coalfield. The Nova Scotia Museum, Halifax, pp. 1-275.

\section{APPENDIX: LIST OF NAMES OF SPECIES AND INFRASPECIFIC TAXA CITED HEREIN, WITH AUTHORSHIPS}

Acrobulbillites Amerom 1973

Alethopteris Sternberg 1825

Annularia Sternberg 1821

Annularia acicularis (Dawson 1862) White 1900

Annularia aculeata Bell 1944

Annularia acuminata Dawson 1862

Annularia asteris Bell 1944

Annularia asterophylloides Sauveur 1848

Annularia asteropilosa Remy and Remy 1975

Annularia calamitoides Schimper 1869

Annularia carinata Gutbier 1849

Annularia cuspidata Lesquereux 1884a

Annularia dawsonii Schimper 1869

Annularia dubia (Sternberg 1825) Wood 1860

Annularia emersonii Lesquereux 1881

Annularia fertilis Sternberg 1825

Annularia fimbriata Walton 1936

Annularia galioides (Lindley and Hutton 1832) Kidston 1891

Annularia inflata Lesquereux 1870

Annularia isperichii Tenchov 1987

Annularia jongmansii Walton 1936

Annularia latifolia (Dawson 1862) Kidston 1886

Annularia latifolia var. minor Matthew 1906a

Annularia ligata Matthew 1906a

Annularia longifolia Brongniart 1828

Annularia longifolia mutation leavittii Matthew 1906a

Annularia microphylla Sauveur 1848

Annularia minima Leggewie and Schonefeld 1961

Annularia minuta Brongniart 1828

Annularia mucronata Schenk 1883

Annularia mucronata forma stellata Bell 1938

Annularia patens (Sauveur 1848) Kidston 1886

Annularia pseudostellata Potonié 1899

Annularia radiata (Brongniart 1822) Sternberg 1825

Annularia radiata forma hirsuta Jongmans and Gothan 1934

Annularia radiata forma karwinensis Jongmans 1937

Annularia ramosa Weiss 1884

Annularia recurva Matthew 1906a

Annularia reflexa Sternberg 1821

Annularia sarepontana Stur 1887
Annularia sphenophylloides (Zenker 1833) Gutbier 1837

Annularia spicata (Gutbier 1849) Schimper 1869

Annularia spinulosa Sternberg 1821

Annularia stellata (Schlotheim ex Sternberg 1820) Wood 1860

Annularia stellata forma longifolia Bell 1944

Annularia stellata forma mucronata Bell 1938

Annularia stopesiae sp. nov.

Annularia subradiata Stockmans and Willière 1952

Annularia vernensis (Arnold 1949) Abbott 1958

Archaeocalamites Stur 1875

Archaeocalamites radiatus (Brongniart 1828) Stur 1875

Asterophyllites Brongniart 1822

Asterophyllites acicularis Dawson 1862

Asterophyllites arcuatus Sauveur 1848

Asterophyllites arkansanus White 1900

Asterophyllites binervis (Boulay 1876) Jongmans 1914a

Asterophyllites charaeformis (Sternberg 1825) Göppert 1844

Asterophyllites comosus Lindley and Hutton 1834

Asterophyllites delicatulus (Sternberg 1825) Brongniart 1828

Asterophyllites discifer Leggewie and Schonefeld 1961

Asterophyllites elegans Sauveur 1848

Asterophyllites equisetiformis (Schlotheim ex Sternberg

1820) Brongniart 1828

Asterophyllites equisetiformis forma equisetiformis Josten 1991

Asterophyllites equisetiformis forma jongmansii Josten 1991

Asterophyllites equisetiformis forma schlotheimii Jongmans and Kukuk 1913

Asterophyllites equisetiformis forma typica Jongmans and Kukuk 1913

Asterophyllites erectifolius Andrews 1875

Asterophyllites fasciculatus Lesquereux 1879

Asterophyllites fasciculatus Matthew 1906a

Asterophyllites fissus Matthew 1906a

Asterophyllites foliosus Lindley and Hutton 1833

Asterophyllites galioides Lindley and Hutton 1832

Asterophyllites germarianus Stur 1887

Asterophyllites gothanii Leggewie and Schonefeld 1959

Asterophyllites gracilis Lesquereux 1860

Asterophyllites grandis (Sternberg 1825) Geinitz 1855

Asterophyllites latifolia Dawson 1862

Asterophyllites lentus Dawson 1871

Asterophyllites lindleyanus Göppert 1844

Asterophyllites longifolius (Sternberg 1825) Brongniart 1828

Asterophyllites longifolius forma striata Weiss 1884

Asterophyllites longifolius forma typica Crookall 1969

Asterophyllites lycopodioides Zeiller 1886

Asterophyllites minutus Andrews 1875

Asterophyllites paleaceus Stur 1887

Asterophyllites parvulus Dawson 1861

Asterophyllites pygmaeus Brongniart 1828

Asterophyllites radiatus Brongniart 1822

Asterophyllites rigidus (Sternberg 1825) Brongniart 1828 
Asterophyllites roehlii Stur 1887

Asterophyllites scutigera Dawson 1862

Asterophyllites striatus Weiss 1884

Asterophyllites subulatus Sauveur 1848

Asterophyllites tayloriorum Cleal and Shute 2016

Asterophyllites tenuifolius (Sternberg 1821) Brongniart 1828

Asterophyllites trinervis Dawson 1868

Asterophyllites vernensis Arnold 1949

Asterophyllum Schimper 1880

Bechera charaeformis Sternberg 1825

Bechera delicatula Sternberg 1825

Bechera grandis Sternberg 1825

Bornia Sternberg 1825

Bornia stellata (Schlotheim ex Sternberg 1820) Sternberg 1825

Bruckmannia Sternberg 1825

Bruckmannia longifolia Sternberg 1825

Bruckmannia rigida Sternberg 1825

Calamites Suckow 1784

Calamites carinatus Sternberg 1823

Calamites ramifer Stur 1877

Calamites ramosus Artis 1825

Calamites suckowii Brongniart 1828

Calamocladus Schimper 1869

Calamocladus binervis Boulay 1876

Calamocladus equisetiformis (Schlotheim 1820) Schimper 1869

Calamostachys Schimper 1869

Calamostachys aculeata Bell 1944

Calamostachys charaeformis Jongmans 1911
Calamostachys grandis (Zeiller 1886) Jongmans 1911

Calamostachys ramosa Weiss 1884

Carpannularia americana Elias 1931

Casuarinites Schlotheim 1820

Casuarinites stellatus Schlotheim 1820

Cordaites Unger 1850 emend. Ledran 1966

Cyperites Lindley and Hutton 1832

Dorycordaites palmaeformis (Göppert 1852) Grand'Eury 1877

Hippurites Lindley and Hutton 1835

Hippurites longifolia Lindley and Hutton 1835

Karinopteris acuta (Brongniart 1830) Boersma 1972

Laveineopteris polymorpha (Dawson 1862) Wagner 2008

Myriophyllites Sternberg 1823

Neuropteris (Brongniart 1822) Sternberg 1825

Palaeostachya elongata (Presl in Sternberg 1838) Weiss 1876

Palaeostachya striata (Weiss 1884) Bell 1944

Palaeostachya wagneri Cleal and Shute 2016

Palmatopteris furcata (Brongniart 1829) Potonié 1892

Paripteris Gothan 1941

Ramicalamus dumosus Matthew 1906a

Renaultia Zeiller 1883

Samaropsis Göppert 1864

Schlotheimia Strernberg 1821

Sphenophyllum cuneifolium (Sternberg 1823) Zeiller 1879

Sphenophyllum myriophyllum Crépin 1880

Sphenopteris sensu lato (Brongniart 1822) Brongniart 1828

Sporangites acuminata (Dawson 1862) Dawson 1871

Trochophyllum Wood 1860

Zeilleria avoldensis (Stur 1883) Kidston 1884

Editorial responsibility: Robert A. Fensome 